Portland State University

PDXScholar

4-1-1969

\title{
The Far East agreements of the Yalta Conference of February 4-11, 1945, and the Sino-Soviet agreements of August, 1945
}

Robert Harold Davidson

Portland State University

Follow this and additional works at: https://pdxscholar.library.pdx.edu/open_access_etds Let us know how access to this document benefits you.

Recommended Citation

Davidson, Robert Harold, "The Far East agreements of the Yalta Conference of February 4-11, 1945, and the Sino-Soviet agreements of August, 1945" (1969). Dissertations and Theses. Paper 700.

https://doi.org/10.15760/etd.700

This Thesis is brought to you for free and open access. It has been accepted for inclusion in Dissertations and Theses by an authorized administrator of PDXScholar. Please contact us if we can make this document more accessible: pdxscholar@pdx.edu. 


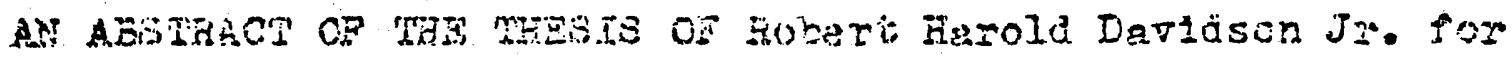
the Yester of Se1ence sn Jeeching psesented An-11 17.1969. Titie; The Far East Agreants of the Yalte Conferanos of

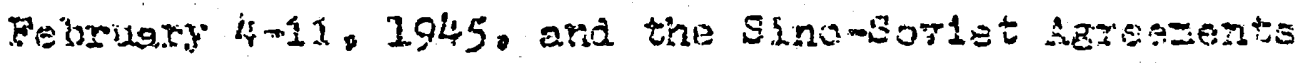
cr Auguet. 1945 .

APESOYED BY MEUPEES OF THE THESIS CONMITTE:

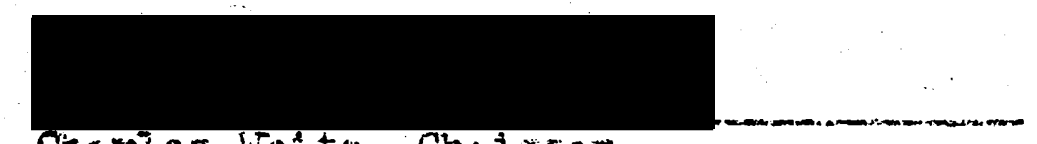

Chexies White, Chatrian

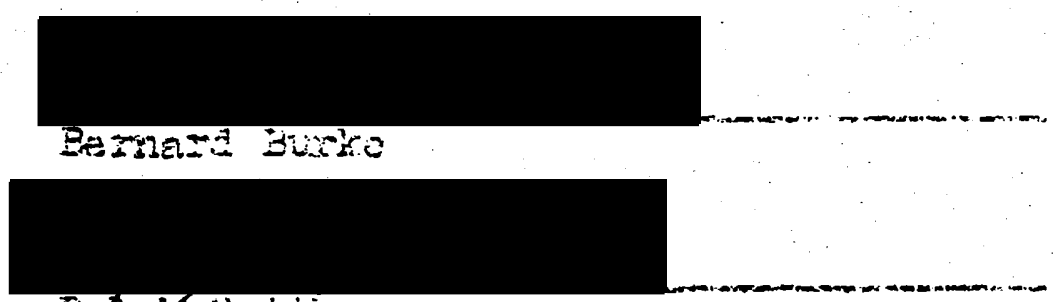

$$
\text { Radp. Siritit }
$$

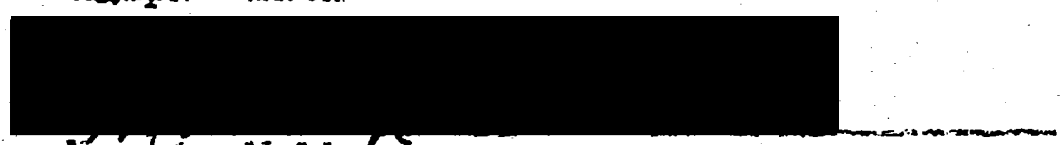

Morpis web?

This saper wiIl present a study of the Far Eest Agreom

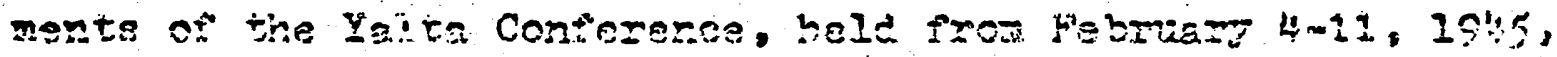

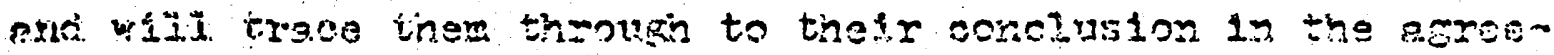

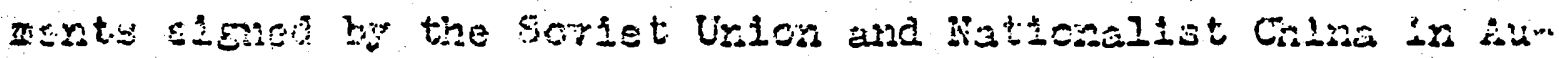

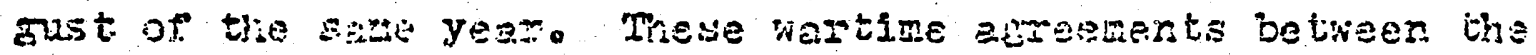

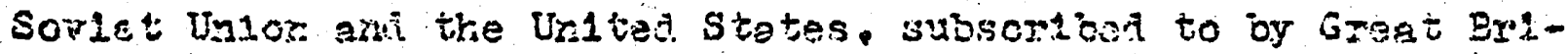
toln and sater lntionsist china, rofocted chn existing iss-

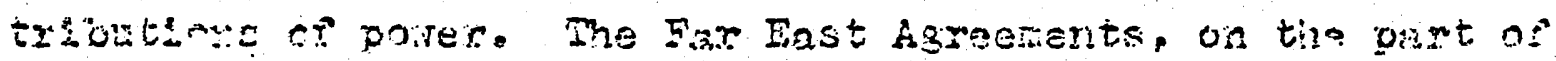


the United States, pere conoluded in the national selr-interest of the United States for reasons thought recessary at the time.

The majority of the information in this paper was obtained from United States Coremment documents and first-hand sccourits by men who took part in, or obserred at, meetings and conferences that dealt w1th the issues being discussed. Feed College documents library supplled the greater bulk of the terlal. with additional materlals being obtained at Portland Stiate University 11 brary and Nultnorah County library. AII other inforration was obtalned on order through the offless of Portiand State University itbrary from various librerles throughout the Facific Northwest.

A background and history of the issues are presented to give the reader the proper perspective before the issues are discussed. Strategic positions ond corditions or porid war II, both prior to and after the Yalta Conference are presented to give the reader a further knowledse of the corditions surmonaIng the issues discussed. The actual negotiations inpolving the Far East Agrements and the Sino-Soriet abresments are discussed in greater detril.

Certaln of the concesslons regarding china anreed upon by the Unlted States at the Yalta Conference were thought necessary at the time. Though it was known that these concessions were made at the expense of China the concluslons drath in this paper w11? shoif that the Far East Asteoments rere a conproniss 
of the continutne viaility of the great powers, pending the Pinal defeat of Tapan, and not $\varepsilon$ compronise of principles on the part of the United States, as belleved. by flany historians and critios.

In the late 1940's, and early 1950!s, after the Chinese Cornunists essued the predorinant position in Crinis, these agreements cafle under heavy attach and eriticism from rang sources, Including a Senate Comaltiee on Foreign Affairs. This paper will show that much of the criticlss end nany of the crities were completely unfustifled in thelr celiefs. In that they faijed to look at the completa ploture and bereritza greatiy from hindsigit.

The Far East Agreements were not $\varepsilon$ iadioaj. shift in Amerlcen China policy. They were not a raotes? ckexge in traditional American pollcy. They were tioknt resessary for both military and political reasons. These asreements here a careful?y worked out plan to accompl sh three eoals: (1) to insure the Sovlet participation in the Passic War at the carliest possible date; (2) to bring about tine best possible enoperation between the Sortet Union and the National1st Governinant of China; and (3) to Iinlt Sorlet expansion In China and prerent China froin being dividcd and torn apart after the war. With the conclusion of the sino-Sorlet negotlations in Ausust of 1945, 1t was thought that these three goals had been acconplished. 
THE FAR EAST AGREENENTS OF THE YALTA CONEERENCE

- OF FEBRUARY $4-11,1945$, AND

THE SINO-SONIET ACREEMENTS OF AUCUST, 1945

\author{
by \\ Robert Harold Davidson, Jx.
}

A thesis submitted in partial fulfillment of the requirements for the degree of

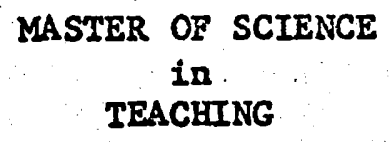

Portland State University

1969 
TO THE OFFICE OF GRADUATE STUDIES:

The members of the Comittee approve the thesis of Robert Harold Dav1dson, Jr. presented Apr11 17, 1969.

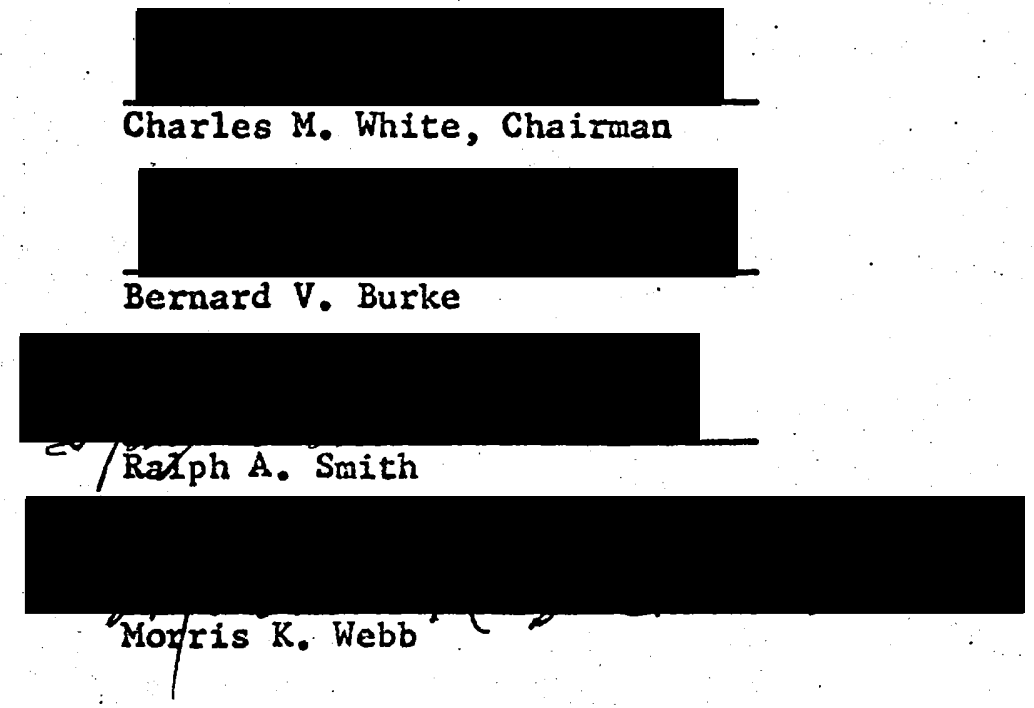

APPROVED :

Charles, 4 . White, Bivision of Social Science $0<12=$

Dlavid Kifalcolm, Acting Dean of Graduate Studies

April 17, 1969 
TABLE OF CONTENTS

CHAPTER

I. BACKGROUND

Early Sino-Sovlet Relations 1

Early Russian Japanese Relations 7

Russian Attempts to Expand $\quad 7$

Japan and the Russo-Japanese War 15

Russo-Japanese Reconcliliation 19

Effect of World War I in the Far East 22

The Soviet Union and the Far East 26

Japan In China $\quad 27$

II. STRATEGIC CIRCUMSTANCES AS OF FEBRUARY 1945

The Soviet Union in Europe 32

The Allied Powers in Western Europe $\quad 35$

Military Strength 38

The Atomic Bomb 40

Declaration on Liberated Europe 41

Soviet Attempts to Stay Out of the War ㄱ. 42

China 43

The Allied Advance in the Pacific $\quad 50$

Future Operations $\quad 52$ 
Japanese Strength and the Need for the

Far East Negotlations and Agreements 68

Influencing Factors and Considerations $\quad 76$

Sino-Soviet Opening Negotiations 86

Final Negotiations and Agreements 93

The Role of the United States in the SIno-Soviet Negotiations

The Sovlet Union and International Law 112

$\checkmark$ THE MONTHS BETWEEN: FEBRUARY 11 TO AUGUST 14, 1945

The End of the War in Europe 116

The War in the Pacific 118

Japanese Attempts to Negotlate Peace $\quad 120$

The End of the War in the Pacific 128

VI conclusion

The Yalta Far East Agreements and the Sino-Soviet Agreements

Reaction to the Sino-Soviet Agreements 144

Yalta Comitments and American Policy 145

The Soviet Union and the War Against Japan 149

Summary 153

FOOTNOTES 


\section{CHAPTER I}

\section{BACKGROUND}

In studying the Far East Agreements of the Yalta Conference, of February $4-11,1945$, it is both vital and necessary to have an understanding of the history, and a background of events and agreements leading up to this conference, as primarily concerns China, Japan, and the Soviet Union.

\section{Early Sino-Russian Relations}

Sino-Russian relations officlally date fron 1689. In that year China signed an agreement with Russia, the first ever between that country and a European power. The object of this treaty, concluded September 9, 1689 , was clearly stated in the preamble:

To repress the insolence of certain rovers, who, passing beyond the bounds of their lands to hunt, robbed, murdered and committed other outrages; as also for setting the bounds of the two countries of China and Russia, and in short, to establish an everlasting peace and good understanding.

The bounds of the two countries were demarcated by the river Kerbechi and the long chain of mountains below the source of the Kerbechi, extending as far as the Eastern Sea. All the rivers and banks, great or sma11, on the southern side of those mountains, as well as all the lands and countries from the top of those mountains southward, were stipulated as belonging to the Empire of China, and all the lands, countries, rivers, and brooks on the other side of the mountains extending northward were stipulated as remaining the possession of the Empire of Russia. 
The territory lying between the sald chain of mountains and the river Ud 1 was undecided, but was to be settled by ambassadors specially designated for the purpose by letters when further details were available. 2

The other important articles of the treaty provided that the fortress of Yaksa was to be completely demolished, that the hunters of the respective empires were not, upon any account whatsoever, to pass beyond the bounds settled above, that neither side was to receive any fugitive or deserter, that persons with proper passports should be suffered to come and go from the territories subject to either empire Into those of the other and to buy and sell whatever they should think fit and to carry on a mutual trade, and finally that bygones were to be bygones and that everything that had passed before, of what nature soever it may have been, was to be buried in everlasting oblivion. 3 This treaty, known as the Treaty of Nertchinsk, while not as precise in language as it could have been, marked the beginning of a period of 170 years of peace on the Siberian-Manchurian border.

Thirty-eight years later Empress Catherine of Russia sent Count Sava Vladeslavich to Peking. Her embassy was the most successful and fruitful of all up to that time. 4 Prior to this, embassies were either not allowed to enter China or not granted an audience by the Emperor of China. The result of Count Vladeslavich's work was the Treaty of Kiakhta, of August 27, 1727, which remained in force until June, 1858, one of the longest-1ived treaties in the history of the world. This treaty fixed the boundary line between Mongolia and Siberla from the Saian Mountains and Sapintabkhain in the west to the Argun River in the east. The valley of the Uda remained undecided. It delimitated the 
frontler from Klakhta to the mouth of the Algun and westward from the same point to Shabina Dabeg, a pass in the Sanyan Mountains. 5

This treaty was favorable to Russia in that by it China lost a large part of the territory claimed by her between the Upper Irtysh and the Salan Mountains and also the territory south-southwest of Lake Baika1. Count Vladislavich declared,

that the newly established frontier is highly advantageous to Russia and that actually the Russian possessions have been extended Into Mongolia a distance of sevęral days' march and in certain sections of even several weeks.

For many years Russia had not been satisfied with the Treaty of Nertchinsk because it checked her expansion to the east. While she had gained much by the Treaty of Kiakhta, she was also dissatisfied because it Iimited her trade with China to a few places. When the Opium War and the Treaty of Nanking, between China and Great Britain in 1842 , completely exposed the weaknesses of China, Russia's ambitions in the Far East were revived and she wanted to get her share of the Chinese spoils. Prior to that, as 1 ong as the Chinese Empire was strong and vigorous as under the reigns of Kang-hsi and Chienlung, or as it appeared to be so after the beginning of the nineteenth century, Russia tolerated the treaty agreements she had made and kept friendly relations with China. 8

China, having just emerged from the throes of one of the greatest rebellions in her history, and pressed by the British and the French on her coast, had no desire to make an enemy of the Russians, with whom she was anxious to preserve friendly relations.

It was this anxiety that induced the Chinese to sign their next series of agreements with Russia. Count Nicholas Maravev, Governor of Siberia, on May 11, 1858, in a conference with Prince Shan, commander- 
In-chief of the Chinese forces of the Amur, presented a 11st of Russian demands. The Chinese at first showed no signs of yielding to the proposals of Maravev, but they finally acceded to them upon the energetic remonstrances of the Siberian governor. 9

With unusual rapidity, the negotiations (lasting only six days), were consummated in the treaty signed on May 16, 1858, known as the Treaty of Aigun. 10 By this treaty the territory on the left bank of the Amur was recognized as Russian, and the territory on the right bank as far downstream as the Ussurri was recognized as Chinese, the territory between the Ussurri and the sea was still to be left open for future delimitation. The rivers Amur, Sungari, and Ussurrl were to be open for navigation for Chinese and Russian vessels exclusively. ${ }^{11}$

A week after the signature of the treaty of Algun, Putiatin, Russian Minister to Peking, negotiated with Chinese leaders, and then signed the Treaty of Peace, Friendship, Comerce and Navigation at Tlentsin on June 13, 1858, which he signed in Ignorance of the MaravevShan agreement. 12

This treaty was mainly conmercial. It provided that the Russians might trade in the open ports, already opened to the nationals of other countries; that Russian consuls might be appointed to such localities as necessary; and that Russian vessels of war and other merchant ships might be repaired and revictualed according to existing regulations. 13

What was most important for Rusaia was that she would receive "most-favored-nation" treatment. Article XII of this protocol gave to Russia the most-favored nation treatment as to political, comercial, and other privileges, hitherto granted to other nations. 14 
Being unaware of the Treaty of Afgun, Putiatin also settled the frontler with the Chinese leaders, not knowing that this had already been done in the earlier treaty. 15

After the Convention of Peking, between China and Great Britain, was signed on October 24, 1860, and that between China and France on the following day, British and French troops withdrew from Peking. General Niehib Ignatieff, Minister from Russia to Peking, succeeding Putiatin, having helped settle the dispute between these countries, and actually boasting that he had saved the Manchu Dynasty by succeeding in getting the troops to withdraw, made demands upon the Chinese Government. 16

Ignatieff had succeeded in getting the Treaty of Tientsin ratified on April 24, 1860, but had falled to secure ratification of the Treaty of Aigun, as the Emperor of China had previously discounted this agreement. 17 However, as a reward for the performance of Ignatieff in the Peking Convention, the Sino-Russian treaty of November 14, 1860 , was signed. By this treaty China gave her official sanction to the Treaty of Algun.

Ignatieff had demanded, besides the Treaty of Aigun territory, the area between the Ussurri and the sea, and, as the Manchu Government was In no position to reject his demands, the Treaty of Peking was signed by Prince Kung. 18

The Treaty of Peking made the Amur and the Ussurri rivers the eastern boundary line between China and Russia. By a stroke of the pen the Amur and Ussurri regions, with a total area of about 400,000 square miles, was ceded to Russia. The western boundary line was also fixed as following the mountains, great rivers and present line of Chinese permanent pickets. It ran from the lighthouse at Shabin-Dabag 
southwestward to Lake Zaisan, thence to the mountains as far as the Kokan's possessions. 19

It was largely due to the combined operations of the French and the British in the south, tying China's hands in the north, that the Russians were able to entrench themselves in the Amur, and it must be remembered that it was through the dubious diplomacy of General Ignatieff in the negotiations of the Treaty of Peking that China ceded to Russia the Primorski Province, which gave Russia access to the coast further south than ever before.

Russia had now gained a far more advantageous position in the Far East than she had ever had previously. Vladivostok was quickly estab11shed, in 1860, and the Russians began to build facilities there. With the completion of this port the Russians would turn ever more to the idea of a year-round warm water port, and they would ultimately make their way south to the waters of the Gulf of Liaotung.

These three treaties - Aigun, Tientsin, Peking - unlike those of Nertchinsk and Kiakhta, were unequal treaties by which China had not only lost vast territory, but had to concede privileges to Russia unilaterally - which put Russia on the same basis as the Wester Powers. For Instance, Russia was to enjoy consular jurisdiction and the mostfavored-nation treatment in China while the latter did not enjoy the same privileges in Russia. Consequently, the relations between China and Russia thereafter could no longer and would no longer be those between two equals, but those between a superior power and an infertor one. 21 Though these treaties were unequal, it must be noted that China was a fully independent nation, as recognized by international law, and therefore fully responsible for any agreements which she saw fit to sign. 


\section{Early Russian-Japanese Relations}

The Russians were also concerned with the Kuril Islands and the 1sland of Sakhalin, in the Yalta Far East Agreements. The Russians had reached the Rurils early in the eighteenth century and by the end of the century began to reach toward Japan itself. Sakhalin formerly belonged to the Chinese Empire, but by early in the nineteenth century the Japanese claimed full control of the island. In February, 1855, a treaty of friendship with Russia, known as the Treaty of Shimoda, was concluded following negotiations between Russian and Japanese representatives. This treaty clearly defined the territorial limits of both countries, acknowledging that Kunashar1, Etorofu, Habomai, and Shikotan were part of Japan proper, and that the Kurils north of Urup Island were under Russian sovereignty. As for Sakhalin, it was agreed not to define its border line, but to continue to apply the customary practices of Japanese occupation of the southern portion and Russian occupation of the northern portion. Nearly twenty years later, in 1875 , a treaty with the Russian government was completed by the Japanese clarifying their positions. Japan was to assume full control of the Kurils and Russia full control of Sakhalin. Article two of this treaty stipulated that the Kuril Islands extended north of Urup Island to Shimshu Island, or a chain of eighteen islands. 22

\section{Russian Attempts to Expand}

The' population of the regions acquired by Russia in the treaties of 1858 and 1860 , did not increase as rapidly as they had expected. "It was a huge emptiness, with no agriculture, no trade, no roads, and, 
of course, no industry."23 For this reason, if for no other, Russia soon became dissatisfied with the acquisition of the Amur and Maritime provinces and her eyes turned to the more populous and fertile lands to the south - Manchuria and Korea. It was clear that control of these two areas was necessary if Russia was to become a dominant power in the Far East. 24

But, Russia had to wait for a proper moment to take action and had first to improve her system of cormunications in Siberia, so that her military might could be brought to the Far East in a comparatively short time. Looking to the future, Tsar Alexander III ordered, in 1891, the construction of the 3,500 mile long Trans-Siberian Rallway. 25

In 1896, Russia and China concluded a secret treaty of alliance. Japan, by defeating China in a war of short duration in 1894-95, had acquired the Liaotung Peninsula. This being a serious blow to Russian ambitions in the Far East, Russia had persuaded Germany and France to join her in advising Japan to abandon Liaotung, which she did. The treaty signed between China and Russia was a result of the gratitude of China for the diplomacy of the Russians in ousting Japan from her mainland. 26

This secret treaty of alliance, signed in May of 1896, the official text of which was not published until 1921, during the Disarmament Conference at Washington D.C., contained, summarily the following:

Article I. The High Contracting Parties engage to support each other reciprocally by all the land and sea forces at any aggression directed by Japan against Russian territory in Eastern Asia, China, and Korea.

Article II. No treaty of peace with an adverse party can be concluded by either of them without the consent of the other.

Article III. During military operations all Chinese ports shall be open to Russian vessels. 
Article IV. The Chinese Government consents to the construction of a rallway across the provinces of Amur and Kirin in the direction of viadivostok. The construction and exploitation of this railway shall be accorded to the Russo-Chinese Bank. The contract shall be concluded between the Chinese Minister at St. Petersburg and the Russo-Chinese Bank.

Article V. In time of war Russia shall have free use of the rat1way for the transport and provisioning of her troops. In time of peace Russia shall have the same right for the transit of troops and provisions.

Article VI. The present treaty shall come into force from the day on which the contract stipulated in Article IV shall have been confirmed. It shall have force for fifteen years. 27

Also included in this treaty was a statement by the Chinese to the effect that:

The juncture of this railway with the Russian railway shall not serve as a pretext for any encroachment on Chinese territory nor for any infringement of the rights of sovereignty of his majesty the Emperor of China. 28

China was positive in her assertions not to allow the Russian Government to build the railway, but the Emperor did consent to an agreement, as Indicated above, between China and the Russo-Chinese Bank for the construction of this railway.

Before 1895, Manchuria was rarely visited by Russians. However, wth the signing of this agreement, Russians began survey work on the railroad, but were delayed by bandit raids in this area. Consequently, in 1896 and 1897, Russian penetration of Manchuria was more theoretical than actual. 29

Nominally, the railway was to be fointly owned and operated, but actually it would be a Russian railway, as it was intended by them. The Chinese president of the company was a figurehead and all the administrative power would ultimately be in the hands of the Russian assistant president. The railway, up on its completion would serve as the instrument of Russian penetration into Manchuria. 
Following the humiliating Sino-Japanese War, 1894-1895, China was

forced to cede the Liaotung Peninsula to Japan. Russia had been able to

force Japan out with the support of Germany and France. In 1898, when

the Germans moved into the Shangtung area, first occupying the port of

Rlaochow, 30 the Russians saw it as an opportunity for her to acquire

Port Arthur and Dairen. She expanded her influence in Manchuria by

obtaining a twenty-five year lease on the Liaotung Peninsula, the very

territory she had denied Japan earlier. On March 27, 1898, a convention

was signed at Peking by which Port Arthur and Dairen, and its adjacent

territory, was leased to Russia:

Article I. For the purpose of ensuring that the Russian naval forces shall possess an entirely secure base on the littoral of northern China, the Emperor of China agrees to place at the disposal of the Russian Government, on lease, the Ports Arthur and Ta-lien-wan, together with water areas contiguous to those ports. This act of lease, however, in no way violates the sovereign rights of the Emperor of China to the above mentioned territory.

Article II. The frontier of the territory leased on the above specified basis will extend northwards from the Bay of Ta-lien-wan for such distance as it is necessary to secure proper defense of this area on the land side.... Upon the determination of this line of demarcation, the Russian Government will enter into complete and exclusive enjoyment of the whole area of the leased territory together with the water area contiguous to it.

Article III. ...the term of the lease shall be twenty-five years from the date of the signature.

Article IV. ...the entire military command of the land and naval forces and equally the supreme civil administration will be given over to the Russian authorities....

Article VI. Both the Governments agree that Port Arthur, as an exclusively military (naval) port, shall be used solely by Russian and Chinese vessels and shall be considered as a closed port to all war ships and merchant vessels of other state8....Ta-1ien-wan, shall be considered open to foreign commerce and free entry will be granted to the merchant vessels of all nations.

Article VIII. ...the Chinese Eastern Railway Company....shall be extended to the connecting branch which is to be built from one of the stations of the main line to Ta-lien-wan, and also, if deemed necessary from the same line to another more convenient point on the 11ttoral of the Liaotung Peninsula.... Consent to the construction of the rallway on the basis indicated shall never under any form serve as a pretext for the seizure of Chinese territory or for an encroachment on the sovereign Iights of China. 31 
The Treaty of Peking had two results, the significance of which is sometimes overlooked: it cut off China In Manchuria from any access to the sea other than through Datren and the inferior ports of Newchwang and Hulutao, and it brought Russia face to face with Japan across a narrow sea. 32

On the part of Russia, a policy of respect for China as a great and equal state had developed into a belief that China had become a negligible factor - merely a land to be exploited at such times and under such conditions as the situation allowed. As practical statesmen, the leaders of Russia now turned their attention to a new power in Eastern Asia, Japan. The Russian Government was controlled by leaders who believed that Japan could be flouted as ruthlessly as China had been. As was soon to be evident, the Japanese Government was controlled by those who believed that Japan's very existence could only be preserved through war.

It was at this time that a group of Chinese fanatics, who resented foreign encroachment, acting with patriotic motives, began a series of anti-Christian, anti-foreigner revolts. The Chinese Eastern and South Manchurian railways, then under construction, were serfously damaged by Chinese rioters. All the Russians in Manchuria were to withdraw either to Siberia or to the leased territory in Liaotung until the news reached Moscow.

This was looked upon by the government in Moscow as an opportunity to occupy Manchuria, and the Russian Government subsequently sent a strong force into Manchuria. The Chinese in Manchuria were no match for the Russians, and by November of 1900, all Manchuria was under Russian occupation. The Chinese at that time negotiated and signed a temporary 
agreement at Port Arthur, on November 11, 1900. The Russians were granted the right to station guards to protect the construction of the 1 rallway, and cities occupied by the Russians were to be administered by them until the complete pacification of the province. 33

When the Chinese attempted to negotiate for the retura of Manchuria In February, 1901, Russia pressed for even stronger concessions. When word of these demands reached other powers, they became alarmed and advised the Manchu Government not to conclude a separate treaty with Russia. 34 With this support, the Chinese refused to sign any agreement, and forced the hand of the Russians. The Russians in turn issued a declaration blaming the interference of other powers in the Sino-Russian negotiations and asserted:

We have promised to withdraw our troops from Manchuria only on the restoration of complete order in China, and only if the actions of other powers will not serve as obstacles to this withdrawal. From our point of view, we cannot consider the restoration of normal order guaranteed until the Court returns to Peking, which, in turn, will be ${ }_{3}$ ossible only in case foreign troops quit the capital of the Empire. 35

The separate negotiations the Russians were attempting with the

Chinese included the following provision:

The Chinese Government will not grant in all the area of the provinces adjacent to Russia, namely Manchuria and Mongolia, as well as in the area of the districts of Tarbagatai, Kuldja, Kashgar, Yarkend, Khotan, and Keri, in the provinces of Kansu, and Sinkiang adjacent to Russia, any concessions for the construction of railroads, exploitation of mineral deposits, or any industrial enterprises whatsoever, to foreign powers and their subjects without the consent of the Russian Government. In all the territory of the above mentioned provinces the Chinese Government will not build railroads by its own means.....

The Chinese, realizing they had support against such demands, did not make a counterproposal to the Russian terms but merely rejected most of them. Russian attempts to take Immediate advantage of the Boxer Rebellion by making a separate agreement with China failed. 37 
This failure ended the period of influence that Russia had enfoyed In China after the war with Japan. Russia had taken the lead in averting the danger and humiliation that would have come from the establishment of Japan in Manchuria, close to Peking, and she had further intimated that she would stand between China and future encroachments on the part of the Japanese. Consequently, Russian influence became predominant at Peking between 1895 and 1902. 38

Russian troops remained in Manchurla. Japan realized that she would be in a disadvantageous position if China should be partitioned and, as Russia had done earlier, sought to alleviate the situation diplomatically. Japan's efforts resulted in the slgning of the AngloJapanese Alliance of January 30, 1902. With these diplomatic developments clearly aimed at her, Russia concluded an agreement with China on terms which included iftele of the aggressive tendencies of earlier demands. Negotiations were concluded on April 8, 1902, in Peking.

In Article I, Russia agreed to the re-establishment of the authority of the Chinese Government in Manchuria, and restored to them the right to exercise governmental and administrative authority. Article II provided for the Russian evacuation of Manchuria in three six-month periods, beginning with the date of the convention. ${ }^{39}$

Within the first six months, the territory west of the Liaotung and the rallways between Shanghaikwan and Shinmingting were restored to Chinese authority. But when the second period expired in April, 1903, Russian troops failed to withdraw fron the west of Shengking and Kirin. Instead, Russia demanded new conditions for further withdrawal.

The exact terms, later known as the Seven Demands, have never been published officially. From what is known though, they contained the 
following provistons:

1. The territory evacuated by Russia should not be alienated through cession, lease, or any other form, to any other power.

2. The Chinese Government will not establish any new treaty ports in Manchuria without the consent of Russia.

3. If China should appoint a forelgner to head any administrative organ, the affairs of the part of northern China where Russian interests predominate will be removed from that agency and placed under a special agency headed by a Russian.

These points were essential for the Russians and were intended to restore the status quo prior to the Boxer uprising. The second group of demands was of lesser consequence, and contained some measures of only

a temporary nature:

4. All rights acquired by the Russians during the occupa$t$ ion of Manchuria will be recognized after the evacuation. In addition, Russia is empowered to take sanitary measures along the railroad line.

5. Russia will retain for its military use the Port ArthurInkou-Mukden telegraph 1 ine as long as the Peking-Inkou Iines exist.

6. The custons commlssar and doctor at Inkou shall be a Russian subject, and the administration and sanitary commission composed of the consuls shall be retained.

7. After the evacuation of the Russian troops the Inkou branch of the Russo-Chinese Bank will continue to function as the agency of the custons.

8. The present form of administration in Mongolia will be retained. 40

The United States, Japan, and Britain protested to Russia over

such demands and warned China not to accept them. The Russian Government categorically denied them, but secretly pressed China for their acceptance. 41 Encouraged by the firm attitude of the other powers, the Manchu Government rejected the Russian demands. Then in September, Russia proposed a new agreement of a milder character but st111 retained the provision that China would never cede to any power any part of the three Manchurian provinces. While China and Russia were still negotiatIng about the evacuation of Russian troops, the Russo-Japanese War broke 
out in February, 1904.

Japan, and the Russo-Japanese War

Prior to the Boxer Rebellion, Japan had desired to come to some understanding with Russia in regard to Korea. In 1898, Russia and Japan had agreed upon principles regarding Rorea, known as the Rosen-Nishi Convention. This agreement, signed in Apri1, 1898, was described by Baron Rosen, Russian Minister to Japan, as "a rather lame and pointless convention." 42 Not being able to come to any real understanding, this agreement did little; both countries recognized the sovereignty and entfre Independence of Korea, and pledged themselves not to interfere in her international affairs, Russia agreeing not to interfere with the development of the commercial and Industrial relations between Japan and Korea, and both countries agreeing not to interfere with the development of the comercial and industrial relations between Japan and Korea, and both countries agreeing not to send advisers to Korea without the consent of the other party. 43

While the primary interest of Russia was in Manchuria, that of Japan was in Korea. Japan had built up substantial commercial and financial interests, and had a natural self-protective and strategic interest, geographic in nature, in preventing Korea from coming under the control of any other power, especially such a strong and naturally expansive state as Russia.

Japan had shown a desire to expand territorially on the Asiatic mainland, to establish further, and protect her interests there, when it had demanded the cession of the Liaotung Peninsula from China in 1895. When she was stopped by the three powers' intervention, she was content 
to accept the status quo, though she naturally would have preferred it otherw1se. But, when Russia was granted the lease to Port Arthur and moved into Manchuria, it disturbed this status quo. Every advance made by Russia brought her into closer contact with Korea and through Korea, with Japan. Russia, on the Korean border and at Port Arthur menaced Japan indirectly, posing a threat to her position in Korea.

Japan, in conjunction with other powers, had repeatedly warned Russia that her policies in China were not acceptable. Japan's Korean policy was of a somewhat different nature. The only serious competition Japan had in Korea was from the United States, and this did not prevent her from establishing a dominant position as the U. S. Interest was primarily economic. This being the situation, Japan was forced to act Independently in this area.

Little success had been attained in Japanese-Russian negotiations when Japan concluded her alliance with Great Britain. This alliance, signed January 30,1902 , offered Japan a certain amount of security which the had not had before. Article I had recognized Japan's special political, as well as commercial, interests, and provided that if these interests should be threatened, she should take measures to defend them by a force of arms. Article III provided that if a third power should attack Japan, England would come to the ald of her ally. 44 The same provisions applied to British interests in China.

Japan realized though, that if at all possible she should conclude agreements with Russia to avoid future trouble. With this in mind, willing to give up any hopes in Manchuria in return for promises of the same in Korea from Russia, she entered into final negotiations with Russia, In August of 1903. 
The Japanese decision to negotiate had been prompted by the reorganization of the Russian controlled province of Rwantung, with Port Arthur on the Liaotung Peninsula, and the province of Amur as a vice-royalty. This move was generally interpreted as evidence of Russia's intention to use this as a base co annex the stretch of Manchuria that separated the Kwantung and the Amur provinces.

In meetings at St. Petersburg, Japan submitted a series of proposals as a basis for discussion. These proposals may be summarized as follows: (1) that both countries agree to respect the independence and territorfal integrity of China and Korea, and to maintain the "open door" principle in those countries; (2) that Russia recognize Japan's special interests in Korea, and concede her right (a) to develop those interests further, and (b) to give advice to the Korean government in the interests of reform. In return, Japan would recognize Russia's special railway interests in Manchuria and concede her the same right of future development within the limitations of the first stipulation. 45

The Russian counter-proposal provided: (1) for a mutual agreement to respect the independence and integrity of Rorea, omitting the similar Japanese proposal as to China; (2) for a Russian recognition of Japan's superior interests in Korea, and of her right to assist in reforming the civil administration; (3) for an engagement by Russia not to interfere with the development and protection of Japanese commercial and Industrial Interests in the kingdom; (4) for a mutual agreement not to fortify on the coasts of Korea so as to menace freedom of navigation in the Straits of Korea, or to use any Korean territory for strategic purposes; (5) for the erection of the portion of Korea north of the thirty-ninth parallel Into a neutral zone; and (6) for recognition by Japan of Manchuria and 
Lts 11 ttoral as in all respects outside her sphere of interest. ${ }^{46}$

Agreements could not be reached. Japan, feeling that the last attempts to negotiate their problems diplomatically had failed, decided on a different course of action. Feeling that she would have the support of the other powers - mainly Great Britain, with whom she had formed an alliance, and the United States, who was avowedly pro-Japanese - she broke diplomatic relations with Russia on February 6, 1904, and on February 8, without a declaration or war, attacked the Russian fleet at Port Arthur and Chemulpo.

The Russo-Japanese War of 1904-1905, ended disastrously for Russia. By the summer of 1905 , circumstances forced St. Petersburg to accept President. Theodore Roosevelt's good offices in arranging peace negotiations. A Russo-Japanese conference met in Portsmouth, New Hampshire, In the United States, in August, 1905, and early in September the peace treaty was signed.

The Treaty of Portsmouth, signed on September 5, 1905, made clear, in Its own terms, that it was intended to be the first step toward a new era of Russo-Japanese cooperation, through a definition of the respective rights and Interests of the parties in Northeastern Asia. 47

By Article II, Russia not only surrendered any claim to national interest in Korea, but also acknowledged that in Korea, Japan "possesses ...paramount political, military, and economic interests," and might therein take "measures of guidance, protection, and control."48 By the same article both nations agreed to "abstain, on the Russo-Japanese frontler, from taking any military measures which may menace the security of Russia or Korean territory. ${ }^{49}$ Thus, was drawn the first solid Iine delimiting Russo-Japanese spheres of interest on the Asiatic continent. 
By Article III, Russia and Japan settled the question of the Kwantung leased territory. Japan assumed control, the article stipulatIng that from then on Russia had no rights within a specified boundary; from then on Japan had certain rights; exclusive to Japan, including the right to maintain troops there and to exercise a certain jurisdiction within it. 50

Article $V$ stipulated that the transfer from Russia to Japan of the rights involved in the lease had to be confirmed by China as the original lessor, and Article VI transferred, also subject to China's consent, that portion of Russia's railroad south of Changchun. 51 Japan wasted little time, and on December 22, 1905, signed with China a treaty whereby China consented to the transfer.

Japan was now established on the mainland for the second time in a decade, this time in a much firmer position. However, it was not long before both Russia and Japan realized that their best chance of exploiting Manchuria lay in cooperation against other powers, and not in competition with each other.

\section{Russo-Japanese Reconciliation}

In a secret convention, lasting from July 17-30, 1907, the two countries came to several understandings. The preamble of the secret convention defined the object of the entente, which was to "obviate for the future all causes of friction or misunderstanding with respect to certain questions relating to Manchuria, Korea, and Mongolla." 52

Article I drew the line of demarcation....desiring to avoid all complications which might arise from competition, Japan undertakes not to seek to obtain on its own account, or for the benefit of Japanese or other subjects, any concession in the way of railways or 
telegraphs in Manchuria to the north of a line defined in the additional Article... and Russia...to the south of the above mentioned 1ine.

The Additional Article drew the line as follows:

Starting from the northwestern point of the Russo-Korean frontier and forming a succession of straight line, the line runs, by way of Hunchun and the northern extremity of Lake Pirteng, to Hsiushichan; and thence it follows the Sungari to the mouth of the Nankiang, thereupon ascending the course of that river to the confluence of the Tola River. From that point, the line follows the course of that river to its intersection with Meridian 122 degrees East of Greenwich.

Article II set aside Korea for special treatment, by the Japanese:

Russia, recognizing the relations of political solidarity between Japan and Korea resulting from the conventions and arrangements at present in force between them... undertakes not to interfere with, not to place any obstacle in the way of the further development of those relations; and Japan, on its part, undertakes to extend in all respects most-favored-nation treatment, to the Russian Government... pending the conclusion of a definitive treaty.

Article III dealt with Outer Mongolia, setting it aside for the Russians for special treatment:

The Imperial Government of Japan, recognizing the special interest of Russia in Outer Mongolia, undertakes to refrain from any interference which might prejudice those interests.

Thus was a new line drawn on the map of Eastern Asia, this one dividing Manchuria into north and south, and separating Outer from Inner Mongolia. While made secretly and without consultation with other nations, which, by virtue of their treaties with China, also had rights and interests in the territories, it was to be respected by the two parties making it for over a decade.

Between the signing of this secret agreement and 1910 , a series of events involving other interested powers made it clear that, unless Russia and Japan took decisive steps to prevent it, the walls of special privilege which they had sought to build up around their respective spheres of interest might be broken down. The Public Convention of 1910 
transferred into a public treaty obligations and agreements already

assumed by the existing treaty of 1907 . Notice was being given to third parties whose interests might be involved.

"Desiring to consolidate and develop the provisions of the secret

Convention signed at St. Petersburg July 17-30, 1907,"54 Japan and

Russia agreed upon the following:

Article I. Russia and Japan recognize the line of demarcation fixed by the Additional Article of the secret Convention of 1907 as delimiting the respective spheres of their special interests in Manchuria.

Article II. The two High Contracting Parties undertake to respect reciprocally their special interests in the spheres above indicated. They consequently recognize the right of each, within its own sphere, freely to take all measures necessary for the safeguarding and the defense of those interests.

Article III. Each of the two High Contracting Parties undertakes not to hinder in any way the consolidation and further development of the special interests of the other Party within the limits of the above mentloned spheres.

Article IV. Each of the two High Contracting Parties undertakes to refrain from all political activity within the sphere of special interests of the other in Manchuria. It is furthermore understood that Russia will not seek in the Japanese sphere - and Japan will not seek in the Russian sphere - any privilege or any concession of a nature to prejudice their reciprocal special interests, and that both the Russian and Japanese Governments will respect all the rights acquired by each of them within its sphere by virtue of the treaties, conventions or other arrangements mentioned in Article II of the public Convention of today's date.

Article V. In order to insure the good working of their reciprocal engagements, the two High Contracting Parties will at all times frankly and loyally enter into communication with regard to anything that concerns matters affecting in common their special interests in Manchuria. In the event that these special interests should come to be threatened, the two High Contracting Parties will agree up on the measures to be taken with a view to common action or to the support to be accorded for the safeguarding and the defense of those interests. 55

Following the completion of the treaties of July 4, 1910, with a promptness which leaves little room for doubts of a connection, Japan proceeded to annex Korea, 56 and in 1911, Russia established a de facto 
protectorate over Outer Mongolia, taking advantage of the Chinese revolt of the same year to do this.

The following year, Japan and Russia executed a new secret treaty. July 8,1912 , representatives of the two countries signed an agreement extending the line drawn in the secret treaty of 1907 , precisely defining the boundary between the added sphere of Russian and Japanese interest in Inner Mongolia, as Russia was already, by prior designation, dominating Outer Mongolia:

Article II. Inner Mongolia is divided into two parts; one to the West, and the other to the East, of the meridian of Peking (116 degrees 27 minutes East of Greenwich.) The Imperial Government of Russia undertakes to recognize and to respect the Japanese special interests in the part of Inner Mongolia to the Bast of the meridian above indicated, and the Imperial Government of Japan undertakes to recognize and to respect the Russian special interests in the parts of Inner Mongolia to the West of the said meridian. 57

\section{Effect of World War I in the Far East}

The outbreak of World War I affected the situation in the Far East as profoundly, if not as sweepingly, as it did in Europe. 58 The European powers' Interests and attention had to be turned to more immediate and pressing matters in their own areas and the further development of Russian interests had to be indefinitely postponed.

Japan, alone of the world powers, could regard this struggle with any degree of detachment. She was free, within the limits of existing obligations, to proceed to obtain from the struggle whatever advantages she could. 59

In 1911, and 1912, Russia had alded the revolt in Mongolia. As a result of this, Russia was in a technical position sonewhat superior to that of Japan, for with respect to the region in which Russian special 
Interests were located, Outer Mongolia, there existed a document, the Russo-Mongolian Treaty of November 12, 1912, which confirmed some of the Russian claims in that area.

In the region in which Japan's special interests lay, southem Manchuria, Japan possessed no such documentary evidence in support of her clalms. Legal justification was inadequate. The first task which lay before Japanese statesmen, therefore, once the menace of Germany in the Far East was removed, was to remedy this deficiency by persuading the Chinese Government to give formal and specific recognition to these claims. This was one motive for the presentation to China, on January 18, 1915, of the so-called Twenty-one Demands.

These demands finally resulted in a treaty between China and Japan which was signed on May 25, 1915. Group II of this treaty primarily concerned Japanese demands relating to south Manchuria and eastern Inner Mongolia. The lease of Port Arthur and Dairen and of the South Manchurian and Antung-Mukden railway lines were to be extended to ninety-nine years; that Japanese subjects might reside and travel in South Manchurla, engage in business and manufacturing, or agricultural purposes; that joint Chinese-Japanese enterprises might be undertaken; that Japanese subjects would be accorded extra territorial rights; that suitable places in eastern Inner Mongolia should be opened to residence and trade; and that the Kirin-Changchun Railway loan agreement should be revised in favor of Japan. 61 By separate notes China conceded that Japanese subjects should have the right to prospect for and to work certain coal and iron mines in specified regions in Fengtien and Kirin provinces; that if China sought foreign capital for rallway construction In Manchurla and eastern Inner Mongolia, application would be made first 
to Japan; and that if China found it necessary to employ foreign

financial, military, or police advisers in Manchuria, it would hire Japanese. 62

Japan was now able to face the rest of the world with a document of the kind usually regarded as an instrument in internation law. On this strengthened basis, Japan faced Russia in a final set of treaty negotiations which were to mark the relations of those two countries before the Russian Revolution.

The preamble of the agreements of June $20-J u l y ~ 3,1916$, stated that:

The Imperial Government of Russia and the Imperial Government of Japan, desiring to consolidate the sincerely friendly relations established by their secret Conventions of July 17-30, 1907, June 21-July 4, 1910, and June 25-July 8, 1912, have agreed on the following clauses designated to complete the above menioned agreements.

Article I. The two High Contracting Parties, recognizing that their vital interests demand that China should not fall under the political domination of any third Power hostile to Russia or Japan, w11l frankly and loyally enter into communication whenever circumstances may demand, and will agree upon the measures to be taken to prevent a situation being brought about.

Article II. In the event that, in consequence of the measures taken by mutual agreement as provided in the preceding article, war should be declared between one of the Contracting Parties and one of the third Powers contemplated by the preceding article, the other Contracting Party will, upon the demand of its ally, come to its aid, and in that case each of the High ContractIng Party will, upon the demand of its ally, come to its aid, and in that case each of the High Contracting Parties undertakes not to make peace without a previous agreement with the other Contracting Party.

Article III. The conditions in which each of the High Contracting Parties will lend its armed cooperation to the other Contracting Party, as stipulated in the preceding article, and the means by which this cooperation will be effected, will be extablished by the competent authorities of the two High Contracting Parties.

Article IV. It is fully understood, however, that neither of the High Contracting Parties will be bound to lend its ally armed assistance contemplated by Article II of the present Convention unless it has assured itself of cooperation, on the part of its allies, corresponding to the gravity of the impending conflict.

Article V. The Present Convention will come into force immediately after the date of signature, and will continue in effect 
unt11 July 1-14, 1921. In case nelther of the High Contracting Parties should have given notice, twelve months prior to the expiration of that period, of its intention to bring the effectiveness of the Convention to an end, it will continue in force until the expiration of one year from the date on which one or the other of the High Contracting Parties shall have denounced $1 t .63$

The Japanese-Russo Agreements came to an end with the estab1ishment of the Soviet regime in Russin, in October, 1917. Japan had Joined the Allied Powers and the United States in recognizing the Kerensky Provisional Government, which had announced that it would accept all the engagements of the Tsarist regime. However, the Bolshevik break with the past was to be international as well as internal. The Bolsheviks made it clear that it would not accept the engagements of the Tsarists, or anything that had been in force prior to that $t$ ime, except what they rould specify.

In the summer and early autumn of 1918, Japan secretly obtained fresh Chinese commitments to certain of the Twenty-one Demands, of 1915. The Chinese Government categorically agreed to the transfer to Japan of Kiachow and the German rights in Shantung, on the understanding that while Japan was to restore the leasehold, it would retain and expand the former German economic privileges in the province. This contract was bound by the Chinese Government's acceptance of advance payments on large Japanese railway loans. 64

After the First World War, Japan': ambition in China was checked by the Nine Power Treaty of 1921-1922, signed in Washingt on D. C. As long as China was disunited, Japan was contented with the status quo in Manchuria, where her influence was now dominant.

The Nine Power Treaty, primarily sponsored by the United States, solemnly bound the signatories to respect the sovereignty, the independence, 
and the territorial and administrative integrity of China. They further pledged themselves to uphold the principles of the "open door" and to assist China in forming a stable government. 65

The Soviet Union and the Far East

Questions and difficulties having arlsen since the formulation of the Soviet Government in Moscow, concerning Mongolia, Manchuria, and the Chinese Eastem Rallraad, a series of negotiations between China and the Soviet Union culminated in May, 1924, in the re-establishment of normal diplomatic and consular relations. The Soviets also volded all Tsarist treaties with and relating to China, affecting her sovereign rights or interests, together with similar Chinese treaties with respect to Russia. The Soviet Government agreed to give up the rights of extra territorlality and consular jurisdiction. The Soviet Government recognized that Outer Mongolia was an integral part of China, and agreed to respect China's sovereignty therein. 66

At this time Manchuria was practically independent of the Peking Government. Peking orders were not obeyed in Manchuria. The Soviet Government, after the conclusion of the agreements with Peking, negotiated with representatives of the Autonomous Three Eastern Provinces of China, at Mukden, and concluded an agreement with them. It embodies all the important points in the agreements concluded with the Peking Government. This agreement subsequently as approved in March, 1925, by the Peking Government as a supplementary document to the Sino-Soviet Agreement of 1924 .

For her part, the Soviet Government, pending the final settlement, was to receive the rights of the Tsarist Government in the Chinese 
Eastern Ra1lway, as provided in the contract of August, 1896, which did not conflict with the present agreements just signed. In the agreement signed with the Manchurian representatives, a provision was added whereby the Chinese government would enter gratis into possession of the Chinese Eastern Railway after sixty years instead of eighty as originally provided. 67

The concluding of these agreements forced Japan to conclude the negotiations it had been carrying on intermittently with the Soviet Union during 1923 and 1924. On January 20, 1925, at Peking, Japanese and Soviet representatives signed an agreement. This agreement provided for the establishment of regular diplomatic and consular relations; recognized the validity of the Portsmouth Treaty, but voided all other treaties made from 1905 to 1917 , until they could be examined at a subsequent conference; and the disagreements over the island of Sakhalin were settled.68 The agreement with China, coupled with the one with Japan at the beginning of 1925, restored the Russian position in Northern Manchuria. And, while the 1924 agreement incorporated a recognition of Outer Mongolia as an integral part of China, and provided for a withdrawal of the Soviet troops, it did not preclude the maintenance of a close relationship and thus, it did not result in a restoration of chinese con$\operatorname{trol}^{69}$

\section{Japan in China}

When in 1928, Manchuria was consolidated and leaders swore allegiance to the central Chinese Government, it came back under a semblance of control to the central government for the first time since 1917 . Fearing further consolidation in China, and, after the civil wars in China during 1929 and 1930, Japan aw its chance and struck. 
On September 18, 1931, Japanese troops in Manchuria provoked an Incident that was to set the Japanese military machine in motion. This occurrence, know as the Mukden Incident, gave Japan a pretext to occupy all of Manchuria, which they did quickly. In March of 1932, they established the independent state of Manchukuo, and in 1933, the province of Jehol was brought under its control. 70 Along with the protocol signed by Manchukuo, granting her recognition by the Japanese, went an agreement stating that Manchukuo confirmed all rights and interests possessed by Japan in Manchukuo at the time of the formation of Manchukuo and that both parties agreed to cooperate in the maintenance of their national security. 71 The Japanese then approached China for a truce - which was signed at Tanghu on May 31,1933 - because time was needed by the Japanese to consolidate and organize their base in Manchukuo.

The Inability of the League of Nations to check aggression greatly disappointed China. The National Government then turned to the Soviet Union for possible help in China's struggle against Japan. The Soviet Union, as its own security was being threatened by the aggressive policy of Japan, was quite willing to join china in this cooperative relationship.

While the Soviet Government was willing to cultivate China's friendohip, its policy toward Japan had been extremely cautious since the Mukden Incident. 72 After the conclusion of the Soviet-Japanese treaty of 1925 , the relations between the two powers were marked by the absence of conflict. Japan had promised to limit her military activities to the southern part of Manchuria, but did not keep her promises, and after Liaotung had been occupled in southern Manchuria, marched her troops into northern Manchuria. For, despite the extremely cautious policy toward the Soviet Union, the Japanese Government, which was not under the domination of the milltarists, was bent upon eliminating the Soviet influence 
in Manchurla completely. 73

Japan's interest was centered on the Chinese Eastern Railway. The Soviet Government, being aware of the possible seizure of the railway, secretly ordered the Chinese Eastern Railway to gradually remove a large part of the rolling stock into Siberia. When Japan heard of this she ordered blockades, and demanded the return of the rolling stock. 74

Now the Soviet Government had to decide elther to defend its interest in the Chinese Eastern Rallway with armed forces, as it had done In 1929, or to withdraw from Manchuria completely. The Soviet Government was not willing to give up its sphere of influence in northern Manchuria, which had existed for more than thirty years, yet it knew very well that its military strength in the Far East was not yet strong enough, and they were in no position to engage Japan in a military conflict.

As a consequence, the Soviet Union proposed to sell their interests In the Chinese Eastern Rallway. After consideration, the Japanese Government advised the Manchukuo regime to accept the Soviet offer. After much negotiation over price, the Japanese Government gave its guarantee to the payments by Manchukug and the agreement was signed at Tokyo on March 23, 1935.75 China protested this sale and refused to recognize it as a valid transaction, but to no avail. After the puppet state of Manchukuo assumed control, the Chinese Eastern Railway was re-named the North Manchurian Railway, and Incorporated into the South Manchurian Railway Company, removing the Soviet Union from Manchuria, and freeing Japan to move freely in that area.

The seizure of Manchuria and Jehol was the first step in Japan's apparent plan gradually to control all of China, and to establish a New Order in Greater East Asia. Step by step, Japan extended its area of 
operations into Inner Mongolia and North China.

The Chinese Communists had declared "war" on Japan as early as 1932, though hundreds of miles separated them from the nearest Japanese troops. 76 Demands for a united front became a factor in Communist propaganda, but at first they were willing to make no concessIons to any group to make possible a true united front against the Japanese.

Internally China had been struggling with the problem of unification during this time. The Chinese Communists had steadily risen in power, and were able to assume control of portions of northern China. The National Government, recognized by the United States in 1928, was engaged in the problem of suppressing Conmunism when Japan was occupying Manchuria. The Japanese actions aroused large sections of Chinese opinion, and the cry for a united front against the Japanese arose. After Chiang Rai-shek, head of the National Government, returned from Sian, where he had been kidnapped by the Chinese Communists, accompanfed by his captor, Chang Hsueh-liang, the establishnent of an entente between the Chinese Comunists and the Kuomintang moved rapidly shead.

After the incident at Marco Polo Bridge, July 7, 1937, which was to be the focal point that brought Japanese intentions fully out in the open, the Communist Central Committee issued a declaration stating its readiness to cope with the national crisis. 77 With this declaration Chlang believed that the Chinese Communists had repented, and were sincere in their professed readiness to join the rest of the nation in the fight against aggression. 78 
On April 18, 1934, Japan announced that any effort by a Western Power to aid China would be opposed by Japan. This, and subsequent unsuccessful attempts by Japan to arrange for the secession of the northern provinces of China, falled to evoke any serious response by any of the powers with interests in the Far East, except for the Soviet Union.

Only the Soviet Union acted In such a way as to indicate that it might as some point resist further Japanese advances. On March 12, 1936, she signed a mutual defense pact with Outer Mongolia, and more important, Stalin, in late 1937, recognized the Kuomintang Government and advised the Chinese Communists to make peace with the Central government and form a common front. She also extended what aid she could, and until the summer of 1942 , supplies were shipped across the Gobi Desert into China, though in small amounts.

Thus, on the eve of World War II, Chiang Kai-shek, as the symbol of a new united China, stood firm against the Japanese. Virtually unaided, and standing alone, China was to reach a peak of strength with its united front that was never to be achieved again, and which did not last long. 
CHAPTER II

\section{STRATEGIC CIRCUMSTANCES \\ AS OF \\ FEBRUARY 1945}

\section{The Soviet Union in Europe}

In the autumn of 1944 , Germany had only seventy-five divisions with which to man a line six hundred miles long and prevent the Soviet Army from advancing from Warsaw to Berlin. Of all the fronts which Hitler was endeavoring to hold, this was the most vulnerable militarily and the most dangerous politically, and yet here the balance of strength was most clearly in favor of his enemies.

In January 12, 1945, the Soviet offensive began on the frozen plains of southern Poland. The German defenses were thin, the reserves weak, and the Russians quickly gained a clear break-through. This was the first stroke of the greatest Soviet offensive of the war. The Soviets had assembled in Poland and east Prussia 180 divisions and at the points where they chose to strike their superiority was overwhelming. 2

The Soviet winter offensive rapidly gathered manentum as fresh armies took up the attack. Crossing the Vistula on either side of Warsaw, the Russian armies isolated the Polish capital and took it on January 17. Farther north Soviet armies broke through and drove northwest toward the Gulf of Danzig. Within a week the whole front had become a seething battlefield and Soviet armor, plunging westward, had advanced nearly a hundred miles. 
Throughout the second half of January, the Russians advanced with giant strides. In the north Soviet armies reached the Gulf of Danzing and the twenty-five German divisions in East Prussia were doomed ${ }^{3}$ In the south Soviet armies broke into Upper Silesia and bore down upon Breslau. While Russian armies were crushing the German flanks, they were also advancing at will through Central Poland, advancing two hundred miles in two weeks astride the road that ran from Warsaw to Berlin. By January 27, they had crossed the German frontier and were less than a hundred miles from the German capital.

Thus, on the Eastern Front, by early 1945, the Russian armies, having thwarted the German attempts to relieve Budapest, were only eighty miles from Vienna; other Russian armies, having surrounded Breslau and secured bridgeheads west of the Oder, were only one hundred twenty miles from Prague; and still a third Soviet army, having reached the Oder at Kuestrin north of Frankfurt, was only forty-five miles from Berlin.

At the time of the Yalta Conference, the Soviet armies stood with all the capitals of Eastern Europe already in their hands, and the three great capitals of central Europe within their grasp. Stalin was to be in a solidly advantageous position. The Conference took place not only on the morrow of a severe Allied reverse in the Ardennes, but at the moment of the Soviet armies greatest victories. 4

In February, 1945, it should be strongly emphasized that British and American military prospects were still grim in both Europe and Asia. They had hardly recovered from the shock of Hitler's counter-offensive in the Ardennes in Europe, and in the Pacific no one could see the end. Though the Allied armies stood poised along the West Wall, ready to 
Invade Germany itself, time and manpower were becoming crucial factors. The British and Americans had almost reached the end of manpower resources at the time of the Yalta Conference, with two wars of incalculable duration still to win. ${ }^{5}$ At this time it was clear that the power of the Soviet army was the great central military fact of the war In Europe. Their advances in the East left little doubt that they had made spectacular recoveries after suffering tremendous losses of both men and territory early in the war at the hands of the Germans.

This buildup and development was primarily the result of the Soviet Union's own abilities to recover and adjust to the wartime situation. There can be little doubt that American lend-lease was of great assistance to the Soviet Union. There can also be no doubt that this assistance was never the deciding factor in the success of the Soviet Union. To the end of the war the Russians managed to supply the great bulk of the actual fighting tools used by her: 92.5 per cent of the planes used; 91.5 per cent of the tanks; 98.5 per cent of the artillery; 95.5 per cent of the shel1s; 94.5 per cent of the cartridges; and 100 per cent of the rifles. 6

It was in transportation equipment that American and British aid was most important. Some 427,284 trucks, 13,303 combat vehicles, and 35,170 motorcycles, and 2,328 ordinance service vehicles. American jeeps were on all Russian fronts. Railroad equipment included 1,900 steam locomotives, sixty-six Diesel locomotives, 9,920 flat cars, 1,000 dump cars, 120 tank cars, and thlrty-five heavy machinery cars, all manufactured for the Russian wide-guage roads. A billion dollars worth of machinery went, $2,670,371$ tons of petroleum products, and $4,478,116$ tons of foodstuffs, 7 mostly consumed by the armies. Vast 
quantities of quartermaster items, medical supplies, industrial equipment and much else were also sent.

A total of approximately $\$ 11,000,000,000$ was sent to the Soviet Union as lend-lease from the United States. This was unquestionably a tremendous amount, but comparatively speaking it was not large, as the war was costing the United States a total of $\$ 8,000,000,000$ a month during 1944. Lend-lease definitely was not what kept the Soviet Union in the war. Almost everyone had expected her to fall within month after the Germans launched their invasion in June, 1941, but she did not. The Soviet Union kept herself in the war.

\section{The Allied Powers in Western Europe}

In May of 1943, with the surrender of the Axis forces in Tunis, no Germans or Italians remained in arms in Africa. A British-American campaign that had begun in November of 1942, was concluded successfully, paving the way for Invasions of the island of Sicily and Italy itself. Sicily was invaded July 10,1943 and by August 17, all Axis resistance had ceased. In turn, Italy was invaded at a number of points by the Allied forces, reaching Rome in June, 1944. German resistance in northern Italy continued until the end of the war, but it was of little consequence strategically.

The defection of Rumania and Bulgaria made the position of Nazi forces in Greece and the Aegean Islands precarious. In September they began to withdraw and move toward Hungary. To hasten the Nazi withdrawal from Greece, British forces landed in carly October, and were greeted with wild enthusiasm. British troops reached Athens on October 18, and turned north. With the help of Greek guerilla forces 
most of the country was cleared of German troops by early November. Meanwhile, the military forces of four countries had been cooperating to drive the Germans out of Albania and Yugoslavia. On October 20, Belgrade was 1iberated, and by the end of 1944, Albania, most of the Dalmation coast, and eastern and southern Yugoslavia, had been freed from Nazi domination. Only in the northwest, in Croatia and Bosnia, did the Germans still retain control.

August 15, 1944, a second amphibious landing was made in France, this time in southern France. The invasion was designed to prevent German forces in the south from moving against the Normandy forces, and to provide the Allies with a supplementary line of supply through the Mediterranean ports, particularly Marseille. The invasion of southern France and the subsequent drive north succeeded beyond all expectations. After liberating southern France, the Allied force moved via the Rhone and Danube valleys to the Belfort Gap. It then joined with the Allied armies in northwestern Europe, and came under General Dwight D. Eisenhower's command.

By the end of 1944 , the Mediterranean Sea was virtually an Allied lake, and attentions could be centered on the Rhine area.

Having finally successfully invaded the European continent in France, on June 6, 1944, the British and American armies were approaching the Siegfried Line by September 1944. Having rejected a plan for concentrating an all-out thrust across the north German plain, the Allies deployed along a six hundred mile front on the Siegfried Line. In preinvasion planning, General Eisenhower had decided to advance against Germany on a broad front. He planned to make his main effort in the north through Belgium, avoiding the forested Ardennes region, along the most 
direct route to the Ruhr industrial area, the vast collection of coal mines and factories which were the main source of German industrial strength. 9

November and the early part of December were spent by the Allies bullding up troop strength for their offensive, the Germans yielding ground very grudingly at this time. The Allies had lessened their supply problem by opening the Scheldt so that the extensive harbor facilities and rallway connections of Antwerp could be utilized by the Allied armies facing the lower Rhineland. They cleaned most of the Alsace and Lorraine areas of German troops and reached the upper Rhine at Strasbourg. They captured Aschen, and thus proved that important bulwarks of the German West Wall could be taken.

With this being the situation, the Allies threatening the West Wall, Hitler gathered his last major reserves for a counter-offensive: It was launched in the weakly held Ardennes sector, with the object of driving to Antwerp, splitting the Allied armies and destroying those in the north. Through surprise it had great inftial success, but it was stopped short of the Meuse River. The Allied forces were successful in regaining the original line by January 31,1945 , and they then resumed preparations for the crossing of the Rhine. 10

The Battle of the Bulge, as the Ardennes struggle came to be known, was one of the greatest pitched battles of the Western Front. The Germans had created a temporary bulge in the Allied lines seventy miles wide and fifty miles deep at the western-most point. This was to be the last great German offensive of World War II.

On the eve of the Yalta Conference, the Allied forces in the west, having just beaten back the last major German offensive, stood poised 
all along the supposedly Impregnable West Wall, ready to Invade Germany Itself. The Americans had captured the first of the Roer dams toward whlch they had been attacking when the Germans began their counteroffensive in the Ardennes. The forces of the Western Powers were now ready to launch their long delayed assult on the Rhineland.

\section{Military Strength}

At the Yalta Conference, at a meeting of the Combined Chiefs of Staff, Winston Churchill, Prime Minister of Great Britain, explained to Marshal Stalin, leader of the Soviet Union, that the Allies had never possessed the same superiority in ground troops over the Germans that the Russians did. ${ }^{11}$ The Allied advance across France had been accomplished with the same number of divisions as the enemy had. The advance had been made possible by a combination of ground and air power, where the superiority of the Allies. was overwhelming. 12

Stalin reported in turn that on the central front in Poland the Soviet army had enjoyed a superiority of one hundred divisions, 180 to eighty, over the Germans as well as overwhelming artillery supremacy. He added that they had nine thousand tanks on the break through sector on the central front. 13

General Eisenhower would have approximately eighty-nine divisions to cover the front from the Mediterranean to the Low Countries, not Including Italy, where there were approximately thirty-two enemy divisions facing an approximately equal number of Allied divisions, though once again the Allied forces would enfoy superiority in fighter aircraft. He further had ten thousand tanks and four thousand heavy bombers available. 14 
Nine of Eisenhower's divisions were French and the rest either British or American. Situated along the Rhine, from north to south, were the First Canadian Army, the Second British Army, the United States Ninth Army, the United States First Army, the United States Third Army, the United States Seventh, and the First French Arny.

In comparison, the numerically superior Soviet amies were advancing along a much larger front in the East. Of all Hitler's mistakes his underestimation of the Soviet fighting forces was perhaps the biggest. The fact that Russia had by this time a more powerful land army than the combined Allied and Axis powers had long been recognized. As early as the Quebec Conference of August, 1943, President Franklin D. Roosevelt and the United States military strategic planners were saying of Russia,"...her post-war position in Europe will be a dominent one. With Germany crushed, there is not power in Europe to oppose her tremendous military forces." 16

The striking power of the Russian forces in Poland and East Prussia was at least twice as great as that of the Western Allies in France and the Low Countries. Before the Russian offensive began, the Soviets had 225 Infantry divisions, twenty-two tank corps, twenty-nine other tank formations, and three cavalry corps. 17 For the attack assembled in Poland and East Prussia, Stalin had 180 divisions, and at the points where he chose to strike, his superiority in men and armor was not threefold but sixfold. 18

The Russian front from the Niemen River to the Carpathians totaled a distance of seven hundred miles. Along this front advanced the main Soviet armies: General Cherniskhovsky advanced toward Koenigsberg; Marshall Rokossovsky along the north bank of the Vistula cutting off 
East Prussia from Central Germany; Marshal Zhukov, south of the Vistula against Pozan; Marshal Konev against Chenstokhov-Breslau; and General. Petrov in the area of the Carpathians against Novo Torg.

Figures released at the end of the war demonstrated the superiority of the Russians, and the Axis Powers, in total manpower, over the other Allied Powers. Germany with a prewar population of eighty million, was mobilizing 313 divisions, Japan was putting 120 in the field; Italy seventy; Hungary twenty-three; Rumania seventeen; Bulgaria eighteen. 20 Among the major Allies the Soviets had a program for more than 550 divisions and the British for more than fifty; the Chinese more than three hundred, though their divisional strength was often little more than regimental according to Allied statistics. The United States was second of the Allies in the mobilization of men and women for military service, and third among all the belligerent nations. The Soviet war effort was putting twenty-two million men and women into the fight. By the time of their defeat, the Germans had mobilized seventeen million. The United States' peak mobilization for the military services was fourteen million. The British Empire mobilized twelve million; China six milition. 21

\section{The Atomic Bomb}

The entry of the United States in World War II caused the abandonment of all projects aimed at developing atomic energy as a source of power, and gave added impetus to the efforts to build an atomic bomb. 22 The basic American military interests in the bomb were twofold: "to provide our armed forces with a weapon that would end the war and do it before our enemies could use it against us," 23 as it was known that the 
Germans were also carrying on experiments involving the use of atomic energy.

At the time of the Yalta Conference "the atomic bomb was still an unknown quantity."24 In 1941, the question of atomic energy was first brought to the attention of Secretary of War Henry Stimson's attention. At that time, he was appointed to a committee that was to report directly to the President. He was to report later that "as time went on it became clear that the weapon [atomic bomb] would not be available in time for use in the Ruropean Theater, and the war was successfully ended by the use of conventional means" in that theater. Furthermore, he also stated that,"the exact circumstances in which the weapon might be used were unknown to any of us until the middle of 1945.125

\section{Declaration on Liberated Europe}

Signed at the Yalta Conference was a Declaration on Liberated Europe, designed to cover situations in liberated Nazl occupied countries. As it read, and was signed, it represented a merging of "conflicting expectations of East and West," 26 The three powers, Great Britain, United States, Soviet Union, consulted with each other "in the common interest of the peoples of their countries and those of liberated Europe. "27

The Declaration reaffirmed the principles of the Atlantic Charter, mainly;

the right of all peoples to choose the form of government under which they will live - the restoration of sovereign rights and selfgovernment to those peoplg who have been forcibly deprived of them by the aggressor nations. 28 
The Far East was not discussed in relation to this Declaration. However, clearly the expectation of the Western Allies was that they would be able to democratize Japan and Korea, and to see a new China pattern itself after their institutions.

As time was to prove, the expectations of the declaration came into conflict, and the interpretations were many and varied. To expect the rest of the world to make itself over in the image of the United States and Great Britain was a mistake of a twofold nature. First, only the United States and Great Britain truly knew what free elections and governments responsible to the w11l of the people were. Secondly, the Soviet Union had no intention at any time of allowing governments unfriendly to her to be formed anywere on her borders. Stalin had stated his position on this many times.

\section{Soviet Attempts to Stay Out of the War}

\section{In 1939, Moscow,}

deciding that a workable alliance with Great Britain and France was unobtainable, that Soviet security might better be served by peace than by war and that noninvolvement in the war to come could best be achieved by a 'deal' with Hitler,

signed a treaty of nonaggression with Germany. 29 This treaty, signed on August 23, 1939, pledged the two parties to "refrain from any act of force, any aggressive act, and any attack against each other undertaken either singly or in conjunction with any other power." 30 This treaty also forbid the joining of any third power against each other, in any way.

Early in 1941, relations with Germany were deteriorating to the point that an invasion of Russia would take place in June of that year, 
Moscow, never-the-less, continued her policy of caution so as not to provoke a conflict with Japan. Every means was being used to forestall a combined attack by Japan and Germany. As a result of diplomatic negotiations between Molotov and the Japanese Foreign Minister, Yosuke Matsuoka, a five year neutrality pact with the Japanese Government was concluded in Moscow on Apri1 13, 1941, which somewhat relleved the tension in the Far East.

However, this treaty, unlike the Soviet treaty with Germany, was one of neutrality. rather than nonaggression and friendship, and lacked the usual clause concerning mutual consultation. It had three main points:

I. Both Contracting Parties undertake to maintain peaceful and friendiy relations between them and mutually respect the territorial integrity and inviolability of the other Contracting Party.

II. Should one of the Contracting Parties become the object of hostilities on the part of one of several third Powers, the other Contracting Party will observe neutrality throughout the duration of the conflict.

III. The present pact comes into force from the day of its ratification by both Contracting Parties and remains valid for five years. 31

If one of the parties wished to void this pact they were to give notice after which the treaty would remain in effect for only one year from the point of notice. This fact would become important after the Yalta Conference, especially to the Japanese, and would cause the Soviets some concern in turn.

\section{China}

At the time of the Yalta Conference, China was suffering from "internal disunity, economic instability (including severe inflation), lack of supplies and general war weariness," 32 all of which impeded 
China's war efforts. Internal disurity was one of the major factors hindering China's war efforts, and from 1941 to 1944, their contribu-. tions to the Allied war efforts were almost negligible.

There were three Chinas at this time; Kuomintang, China, Communist China, and the Wang Ching-wel puppet government installed in Nanking on March 30, 1940. Kuomintang China, under Chiang Kal-shek, was weakened by dissident elements and widespread popular discontent. Communist China's materials and popular strength was growing. The puppet Chinese Government was under the control of the Japanese, and the other two were not working together against Japan for the good of China as a whole.

The Kuomintang Government had set up a strong military cordon around the Chinese Communists in northwest China and was spending a majority of its energies with this policy of containment. However, President Roosevelt belleved at that time, February, 1945, that General Albert $C$. Wedemeyer, American commanding general in China, replacing General Joseph Stilwell, and the new Ambassador, General Patrick J. Hurley, were having more success than their predecessors, and had made progress In bringing the Communists in the North together with the Kuomintang Government. He further believed that the fault lay more with the Kuomintang and the Chungking Government than with the Communists. 33

The Communists had earlier declared that they were willing to submerge their differences with the Central Government and place their troops under the personal command of General Joseph St1lwe11, American chief of staff and field commander under Chiang KaI-shek, if Chiang Kai-shek, also the military head of Nationalist Chinese forces, would do the same for all Nationalist troops in China. 34 
Territory controlled by the Chinese Comunists covered large portions of North China and disconnected areas to the east and south. The Comnunists claimed to have 500,000 regular troops and two million militia. 35 In late 1944, on paper, the Nationalist army consisted of 324 divisions, sixty odd brigades and eighty-nine so-called guerilla units of about two thousand men each. This was misleading as to Nationalist China's strength as the average strength per division, was less than five thousand men. The troops were unpaid, unfed, and were suffering from sickness and malnutrition. Their equipment was old, inadequate, and unserviceable. Their training was almost nonexistent and the officers were Inadequate for the task they faced. They had no artillery, transportation, medical supplies, or other essentials. ${ }^{36}$

In Anglo-American grand strategy, the war against Germany came first. Second came the great "triphibious" movement across the Pacific toward the Japanese island empire. The China-Burma-India theater was a poor third. 37 Actually, the formation of this strategy was already agreed upon before Pearl Harbor, in May, 1941. The United States Joint Army and Mavy Basic War Plan stated:

Since Germany is the predominant member of the Axis powers, the Atlantic and European war is considered to be the decisive theater. The principal United States military effort will be exerted in that theater, and operations of United States forces in other theaters will be conducted in such a manner as to facilitate that effort. ${ }^{38}$

Whether this decision would have been the same had it been reached after the Pearl Harbor attack may be questioned. However, as it was, strategically, the object of American policy in the Far East was "to keep China in the war, and so to strengthen her that she might exact a constantly growing price from the Japanese invader." 39 
As the situation developed, the reinforcement of China depended on the maintenance of a line of supply through Burma, if necessary by air, If possible by land. As the war developed, the United States was forced to send what aid possible over the "Burma Hump" by air from India to China. The major portion of supplies sent over the "Hump" was given to the maintaining of a considerable air force there of some six hundred planes. It was expected that command of the air could be maintained in China, and bases built from which the mainland of Japan could be bombed. General Stilwell had argued that as soon as the Japanese felt the effect of attacks from bases in China, they would stage an attack to take the bases from us, and that the Chinese troops available for protection would not be competent to prevent it. 40

This proved to be the situation as the summe $r$ and autumn of 1944 , brought further Japanese advances in China. As the year closed, it appeared that China was desperately close to defeat, closer than at any other time during the long years of the Japanese invasion and occupation. The Japanese offensive was aimed at knocking out both China, and the Increasing American air power in that country. By the end of the year it looked as if this offensive was a success, as the American air bases in East China had been cut off from their source of supply in the west, and in India. Moreover, a number of American bases had to be abandoned. as the Japanese advanced, and the protective Chinese amies in the east were now disorganized units. 41 The United States had lost all its bases east of Kunming, and had nothing to show for all the effort and expense involved up to that time. 42

A loosely organized country, with little or no industry in most parts, China had managed to hold out 80 far. Willing to trade space for 
time, China had yielded territory where necessary to save its armies. ${ }^{43}$ There simply were no arterial centers which Japan could press and force China to submit. During the greater part of the war, occupled China, exclusive of Manchuria, comprised about 500,000 square miles, which stretched across North China and down the coast, and included most of China's larger cities. China had moved its capital whenever necessary, and was now operating from Chungking.

Nationalist China had seldom been in any condition to take the offensive. Until the Chinese forces trained in India by Americans were transported back over the mountains, providing the only really dependable, well-equipped fighting force in China, Chiang Kai-shek's forces were able to do little as the Japanese almost cut China in half. The Communist Chinese in the north, malaly with guerilla action, were having much more success, and were giving the Japanese considerable trouble.

China had been almost a negligible factor to this time. The Nationalists hated the Communists to the extent that often they did nothing but watch them, the Nationalists fearing the Communists would gain advantages in the government. The result was that they often appeared to be engaged in an undeclared civil war continuing at the same time, with neither appearing to care much about the war against Japan. 44 . In Stilwell's opinion, Chiang Kai-shek would not make an effort to fight seriously. He wanted to "finish the war coasting, with a big supply of materlals, so as to perpetuate his regime. He had blocked us for three years and will continue to do so," wrote Stilwell, just before he was relieved. 45 
However, by February, 1945, General George Marsha11, United States Chief of Staff, was able to picture the Chinese situation as being considerably changed for the better as time passed. He was able to point out that well-trained Chinese troops were now in China, having been transferred there from Burma. Secondly, the opening of the Burma Road had meant that artillery from the Allies for the Chinese army, had been able to go through. Thirdly, if operations in Burma continued to go well, additional trained Chinese troops could move back to China, and it was hoped that an effective reinforced Chinese corps would soon be in existence. 46

Ultimately, the role China had been scheduled to play - 1.e., to maintain its territory as a strategic outpost, as the base from which to borab Japan, and as the battlefield on which the Allies supposed the final confronting and defeat of the Japanese force would come - was discovered to be unnecessary, as the naval wax in the Pacific was now going well.

In the conversations at Yalta, Prime Minister Churchill had Inquired of President Roosevelt, "if he had not been somewhat disappointed at the results accomplished by the Chinese?" President Roosevelt replled that, "three generations of education and training would be required before China could become a serious factor." 47 .

If the armies and government of Generalissimo Chiang Kai-shek had been finally defeated, Japan would have been left free to exploit the tremendous resources of China without harassment. It might have made it possible, when the United States and Britain had finished the war in Europe, and assaulted the Japanese home islands, for the government to flee to China and continue the war on a great and rich land mass. 48 To 
prevent this, it was determined in 1943, that by means of a projected Allied attack across the India-Burma frontier, it would be possible to drive the Japanese from Northern Burma and achieve the objective of reopening surface communications with China.

The preliminaries to this operation began in October, 1943, just prior to the Conference of Cairo and Tehran. By May of 1944, the Allied forces under General Stilwell had fought their way into the airfield at Myitkyina, the key to Northern Burma. Patrols of Stilwell's forces and those of Chiang Kai-shek's, who were crossing the Salween River at the time when Stilwell was advancing on Myitkyina, met at Tengchung in the summer of 1944, establishing limited control over Northern Burma for the first time since the Japanese had assumed control.

In the fall of 1944 , it became obvious that the mission of reestablishing communications with China, via Burma, could be accomplished, and as the future objectives of the forces in Southwest Asia and China were to grow continually more divergent, it appeared advisable to make a clear division of the two theaters. 49 Accordingly, the theater area of China-Burma-India was separated into the India-Burma, and the China Theaters. Lieutenant General Daniel Sultan, of the British Army, was given command of the India-Burma Theater, and Major General Albert Wedemeyer, United States Army, was appointed comander of United States forces in China, succeeding General Stilwell as Chiang Kai-shek's Chief of Staff.

The Burma campaign continued with intensity during the monsoon seas on of 1944. Chinese, American and British troops were disposed along the Chindwin River, north of Kalewa and from the upper Irrawaddy to lungling. It was planned to drive southward through Central Burma to 
Mandalay, and Admiral Louis Mountbatten, British commander, was preparing operations to seize Rangoon amphibiousily from the south. 50

At the close of the monsoon season, Chinese, American and British troops under the immediate command of General Sultan advanced southward astride the Irawaddy River, captured Shwegu in early November, and by December had cleared the projected tract of the supply road to Bhamo. Sultan pressed on and made junction with the Yunnan armies on the old Burma Road on January 20,1945. The road from Ledo, in the Indian province of Assam, into North Burma and Kunming, China, known as the Stilwell Road, was now clear. On January 28, 1945, a convoy of American trucks and materials from India crossed the Burma-China frontier. 51 Communications reached the Yalta Conference that land communications had been opened through North Burma.: Though the road was rough, little better than a path in part, motor vehicles and guns could now be delivered by that road to China.

The Allied Advance in the Pacific

General Douglas MacArthur, of the United States, was in conmand of operations in the South Pacific. The advance across the Central Pacific was placed under the command of Admiral Chester Nimitz, also of the United States. It was General MacArthur's intention to proceed by a series of envelopments up the coast of New Guinea and into the Philippines. The United States now enjoyed superiority both on the sea and in the air. 52 MacArthur was therefore able to land his troops where the Japanese were weakest, and confine their stronger forces in pockets, from which, because of incredibly difficult terrain, and air and sea: superiority, they could never break out. "The enemy garrisons which have been by passed in 
the Solomons and New Guinea represent no menace to current or future operations. Their capacity for organized offensive had passed," MacArthur reported to General Marshall as he prepared to invade the Philippines. 53 At the time of the Yalta Conference, some 200,000 to 300,000 Japanese troops had been left trapped in these bypassed positions and a comparable number could be considered as cut off in Malaya, the Netherlands, East Indies, and even Burma. 54

The conquest of the north coast of New Guinea was completed by August, 1944. This victory was the first leg on MacArthur's long return fourney to the Philippines. On October 20, 1944, he splashed ashore at Leyte. Island in the southern Philippines. 55 By December 26, the battle of Leyte had ended, except for mopping up operations. During the later stages of that battle, a land force was sent into Southern Mindoro, an Island off the coast of Luzon. Within twenty-four hours of this landing, American planes and PT boats were operating off the southern coast of Luzon. In the first week of January, 1945, a new American assult force gathered east of Leyte, and proceeded to invade Luzon by effecting a landing in Lingayen Gulf, tts classic point of greatest vulnerabiltty. Fighting continued throughout the month, with numerous other landings being made on Luzon, until February 4, the 11th Airborne Division was able to enter the northeast portion of Manila, the largest and most important city in the Philippines. 56

Success crowned the American attacks on Japanese island strongholds in the Pacific. In May and August, of 1943, Attu and Kiska in the Aleutians were easily retaken. In November, 1943, Tarawa and Makin, both in the Gilbert Islands, came under Allied domination. In January and February, 1944, the key outposts of the Marshall group succumbed. 
After bitter resistance, the major islands of the Marlanas fell in July and August, 1944. With these islands now available, the first sustained air attacks on Japan were launched by bombers in November, 1944.

The gigantic naval battle of Leyte Gulf was concluded October 26, 1944 , after three days of battle. By these battles, as Leyte Gulf encompassed several actions, it was apparent that the Third and Seventh United States fleets had virtually eliminated Japan as a sea power. 57 In this series of battles the Japanese lost virtually their entire fleet.

\section{Puture Operations}

The choice of future operations, as of February, 1945, was now dependent on the results of present operations in Luzon and on the date of the termination of the war in Europe, from the Allied standpoint. 58

During the three years of fighting that took place in the southwest Pacific area, eight Japanese armies had been either defeated or rendered powerless to conduct more than delaying actions. The advances of the forces under MacArthur, and control of the sea by Admiral Nimitz, had helplessly cut off large numbers of troops that constituted no threat to an Allied drive toward Japan.

Knowing that invasion was not long off, Japan began to husband her now waning resources for the final battle. But she would not receive any help from the southwest Pacific. General MacArthur stated that these enemy troops, "were unable to conduct an orderly retreat, in classic fashion, to fall back on Inner perimeters with forces intact for a last defense of Japan's main islands." It was a situation unique in modern war. MacArthur stated, "never had such large numbers of troops been so outnumbered, separated from each other, and left tactically impotent to 
take an active part in the final battle for their homeland."59

President Roosevelt stated at the Yalta Conference that he hoped 1t would not be necessary actually to invade the Japanese island, and would do so only if absolutely necessary. However, the military continued to plan for the Invasion of the Japanese islands, would it be necessary. The Japanese had 4,000,000 men in their army and he hoped by intensive bombing to be able to destroy Japan and its army and thus save American Iives. 60

However, tentative plans were being prepared aiming at an attack on Kyushu in September of 1945, and an invasion of the Tokyo Plain on the main 1sland of Honshu in December of 1945. The actual dates of these operations were dependent on the defeat of Germany, as they involved the use of forces which would have to be redeployed from Europe after the Naz1 defeat. The length of time required for redeployment varied between four and six months, depending on whether the troops involved had actually been committed in Europe. It was intended to use this interval to obtain positions designed to assist in the final defeat of Japan, 61 as subsequent ly was done.

Secretary of War Stimson described the Army's attitude on the Japanese war, even as late as July, 1945, in the following manner:

...there was a very strong possibility that the Japanese Government might determine upon resistance to the end, in all areas of the Far Bast under its control. In such an event, the Allies would be faced with the enormous task of destroying an armed force of five million men and five thousand suicide aircraft, belonging to a race which had already amply demonstrated its ability to fight literally to the death.... The total United States military and naval forces involved in this grand design [1.e., invasion of the main islands] was of the order of $5,000,000$ men... ese estimated that if we should be forced to carry this plan to its conclusion, the major fighting would not end until the latter part of 1946, at the earliest. I was informed that such operations might be expected to cost over a million 
casualities, to American forces alone. 62 Additional large losses might be expected among our al11es....62

Of almost equal concern to the military staffs were the Japanese troops in Manchuria.

Described as the cream of the Japanese Army, this selfcontained force, with its own autonomous command and industrial base, was believed capable of prolonging the war even after the islands of Japan had been subdued. 63

This was the situation on the eve of the Yalta Conference. The heads of the three Great Powers would meet February 4-11, 1945, at Yalta, in the Crimea, to solidify final plans to bring about the defeat of Germany, and to attempt to settle the problems that would come with their final surrender.

The Far East problems were not discussed in any depth or at any length, but before the conference ended, President Roosevelt and Marshal Stalin would agree on the conditions for the entry of the Soviet Union into the war against Japan. 
CHAPTER III

THE FAR EAST

AGREEMENTS

\section{American Tradition and Policy}

American interests in the Far East date from the eighteenth century. Until World War II, American interests, unlike those of Russia and Japan, were in large measure economic. "The dream of four hundred million customers fired American imagination," even though this dream had persistently refused to come true. 1

The United States' policy toward China had been clearly stated on numerous occasions since 1900. The principles of "equal commercial opportunity" and, "the maintenance of the territorial and administrative integrity of political independence of China" had guided American policy toward China for more than half a century. ${ }^{2}$ The basic American objectives in the Far East had been defined by Secretary of State John Hay in the Open Door Notes of 1899 and 1900 - to preserve the commercial Open Door, and the territorial integrity of China. It was at this time also that President Theodore Roosevelt and Hay came to the conclusion that the American people would neither fight for the Open Door and the territorial integrity of China, nor support a Far East policy based on the use of force. Noninterference in internal Chinese affairs thus came to be accepted as a traditional policy of the United States. 
In 1922, the United States had succeeded in having the principles of Its policy toward China written into the Nine Power Treaty, at the Washington Conference, signed February 6, 1922. This treaty proved to be the only formal and specific affirmation of the Open Door ever agreed to by the major powers, except for Russia and Germany, who did not take part in the Washington Conference.

This treaty bound each power: ${ }^{4}$

I. To respect the sovereignty, the independence, and the territorial and administrative integrity of China;

II. To provide the fullest and most unembarrassed opportunity to China to develop and maintain for herself an effective and stable government;

III. To use their influence for the purpose of effectively establishing and maintaining the principles of equal opportunity for the commerce and industry of all nations throughout the territory of China;

IV. To refrain from taking advantage of conditions in China in order to seek special rights or privileges which would abridge the rights of subjects or citizens of friendly States, and from countenancing action inimical to the security of such States. 5

The United States clearly sympathized with the efforts of the Chinese people to achieve those political institutions which would best meet their needs in the modern world, and had followed a policy of strict neutrality concerning internal Chinese affairs, to this time. 6 And in 1927, Secretary of State Frank B. Kellogg reaffirmed this aspect of American policy when he stated:

The United States had always desired the unity, the independence and prosperity of the Chinese nation.... The Government of the United States has watched with sympathetic interest the nationalistic awakening of China and welcomes every advance made by the Chinese people toward recognizing their system of government... The Government of the United States had endeavored in every way to maintain an attitude of the most careful and strict neutrality as among the several factions that have disputed with one another for control of China.... 
The United States departed from the policy of "strict neutrality among the several factions disputing for control of China" in 1928, by recognizing the Nationalist Government, on July 25, under the leadership of Chiang Kai-shek, as it appeared that the situation there had somewhat stabilized.

Secretary Kellogg's statement on the recognition of Nationalist China once again confirmed the now traditional policy of the United States with regard to China:

.....we do not believe in interference in their internal affairs, we ask of them only that which we look for from every nation with which we maintain friendly intercourse, specifically, proper and adequate protection of American citizens, their property, and their lawful rights, and in general, treatment in no way discriminatory as compared with the treatment accorded to the interests of nationals of any other country. 8

Secretary of State Henry L. Stims on, in February, 1932, firmly stated that American policy with regard to China was based on the Nine Power Treaty, of February, 1922. In a letter to Senator William Borah, of Idaho, chairman of the Senate Foreign Relations Coumittee, he stated:

This treaty thus represents a carefully developed and matured international policy intended, on the one hand, to assure to al1 of the contracting parties their rights and interests in and with regard to China, and on the other hand, to assure to people of China the fullest opportunity to develop without molestation their sovereignty and independence according to the modern and enlightened standards believed to maintain among the peoples of this earth.?

During the years of the undeclared war between China and Japan, the United States, on numerous occasions, protested against the violation of its rights in China by Japan. But these all came to no avail, and the United States was not willing, following the traditional policy established during the Presidency of Theodore Roosevelt, at any time to use force to see that Americans were assured of their rights. 
This policy of non-involvement in the Far East was clearly evident with the sinking of the American gunboat Panay, which was cruising on the Yangtze River when it was bombed and sunk with the loss of two lives and thirty wounded, on December 12, 1937, The refusal of the United States to do anything but protest to the Japanese government, and their obvious unwillingness to become involved on the continent, was clearly evident with this incident.

However, when the situation in China reached the point where the Chinese were in danger of succumbing to the Japanese, the deciston was made to send lend-lease aid to China. The President, on May 6, 1939, in accordance with the provisions of the Lend-Lease Act, declared the defense of China to be vital to the defense of the United States. 10

This was to be the extent of United States involvement in China to this time, even though there were further incidents after the Panay Incident - mistreatment of American citizens and American property until July, when a American military mission was established in China, and American fliers, known as Chennault's Flying Tigers, were beginning to fight the Japanese in China. Though the United States would eventually go to war with Japan because they insisted on maintaining their policies, they would not take the first step and would become fully Involved militarily only after they were attacked at Pearl Harbor, on December 7, 1941 .

By the end of September, 1941, the Chinese Government was allowed to hire one hundred volunteer American pilots and 181 American ground personnel to man and service one hundred $P-40$ airplanes provided under lend-lease. 11 These were the beginning of attempts by the United States Government to keep China in the war. The extension of a half-billion 
dollar credit in 1942, the sending of supplies by air over the treacherous Burma Hump, and the dispatch of military advisers to Chungking were all manifestations of American good will.

Comparatively speaking, these were little more than manifestations of good will. 12 The decision had already been made by the Allied leaders to concentrate on the war in Europe before turning full attention to the Pacific, and the amount of supplies sent to China were totally inadequate for China to present much of a military threat to Japan. With the situation in China becoming increasingly worse, and the difficulty, after the closing of the ground route to China from Burma, the ports having been sealed off prior to this, in getting supplies into China, it was not possible to strengthen and supply the Chinese armies adequately. And the decision had been made that the majority of the supplies that were flown in would go to maintaining an air force in China.

In January, 1943, though, as a juridical declaration of independence for China, a pact was signed between the United States and China that went far toward putting her on an equal footing with the other United Nations. On January 11, this pact officially renounced American extra-territorial rights in China. ${ }^{13}$ A further move on the part of the United States to equate China with other powers was the removal of long standing discriminations against both Chinese immigrations, and the right of Chinese to becone citizens of the United States, with the passage of an act to this effect on December $17,1943^{14}$

Throughout the war, President Roosevelt and his advisers were maturing plans to strengthen China after the war and establish her as a great power, even though Roosevelt realized that China would not be in a position to rightfully assume her place as a world power for some time. ${ }^{15}$ 
It was further realized that China would have to stabilize internally, and establish a good working relationship with the Soviet Union.

This knowledge did not deter President Roosevelt though, and steps were taken whenever possible to demonstrate the intentions of the United States to treat China as an equal among the major powers, and to see, as best she could, that the other countries also did. The United States insisted that China be included as a signatory, together with the United States, Great Britain, and the Soviet Union, of the Declaration of the Four Powers on general security, signed in Moscow, on October 30, 1943. This was done over the violent objections of the Soviet Union. 16

The President won Churchill's and Stalin's seeming approval 17 at Cairo (November 22-26, 1943), and Tehran (November 28-December 1, 1943), of the Calro Declaration, issued on December 1, 1943. This definition of the Anglo-American policy in the statement, which strongly influenced the Department of State's subsequent work on the Far East peace, declared:

The Three Great Allies are fighting this war to restrain and punish the aggression of Japan. They covet no gain for themselves and have no thought of terxitorial expansion. It is their purpose that Japan shall be stripped of all the islands in the Pacific which she has seized or occupled since the beginning of the first World War in 1914, and that all the territories Japan has stolen from the Chinese, such as Manchuria, Formosa, and the Pescadores, shall be restored to the Republic of China. Japan will also be expelled from all other territorles which she has taken by violence and greed.18

China participated as a Great Power in the Dumbarton Oaks meetings in the summer and fall of 1944, and was one of the sponsoring Powers of the United Nations Conference of International Organization, which met at San Francisco in Apri1, 1945, and which formulated the 
Charter of the United Nations. The Charter granted China a permanent seat on the Security Council as one of the major powers of the world all at the insistence of the United States.

It is necessary to note at this point that neither stalin or Churchill shared Roosevelt's views on China, though he was able to persuade them to go along with his plans. Churchill was to refer to them as "the Great American Illusion," and stated in August of 1944:

That China is one of the world's four Great Powers is an absolute farce. I have told the President I would be reasonably polite about this American obsession, but I cannot agree that we should take a positive attitude on the matter.... while not opposing the President's wish, I should object very much if we adopted other than a perfectly negative line, 19 leaving him [Chiang] to do the needful with the Russians.

The Yalta Conference Briefing Book policy papers, prepared by the State Department, contained statements that the United States desired a "strong, stable and unified China with a government representative of the wishes of the Chinese people,". and "the development of an integrated and well-balanced Chinese economy and a fuller flow of trade between China and other countries." 20 The policy statement continued with the recommendation that the United States "assume the leadership in assistIng China to develop a strong, stable and unified government in order that she may become the principal stabilizing factor in the Far East," as "an unstable, divided and reactionary China would make stability and. progress in the Far East impossible." 21 However, the State Department also regarded "Sino-Soviet cooperation as a sine qua non of peace and security in the Far East," and sought to "aid in removing the existing mistrust between China and the Soviet Union and in bringing about close and friendly relations between them." And, it was stated, the 
United States would,

interpose no objection to arrangements voluntarily made by China and the Soviet Union to facilitate the passage of Soviet trade through Manchuria, Including the possible designation by the Chinese Government of a free port. 22

Of significance is the following statement, included in the State

Department Briefing Book. This belief would undoubtedly influence the

United States in refusing to interfect itself into the Sino-Soviet

negotiations that would take place later that year.

We believe that China's territorial integrity should be respected, including her claim to sovereign rights over such outlaying territories as Tibet and Outer Mongolia. We would not oppose, however, any agreement respecting those two territories reached by process of amicable negotiation between China and other interested governments. We hope that the Chinese government will meet the aspirations of the native peoples of such territories for local autonomy. 23

These recommendations are of the utmost importance in understandIng why the United States would be able to make the Far East Agreement with the Soviet Union. And why these were not in conflict with traditIonal United States policy toward China.

Japanese Strength and the Need for the Soviet Union

By February, 1945, the American and British military organizations were fairly certain that if need be they could defeat Japan without Soviet assistance. However, they were looking ahead and there was little question but that it might be necessary to fight two extremely hard and costly military campaigns: (1) the Invasion of the Japanese home islands; and, (2) a campaign against large Japanese armies on the mainland of Asia.

The amphibious operations of the spring, summer and autumn of 1944 , carried Allied Forces such great distances across the Pacific that in 
February, 1945, they were enabled to begin the assault upon the inner defenses of the Japanese Empire itself.

General Marshall stated at the Far East hearings, to the Joint Comittee on Military Situations in the Far East in 1951, that:

The Japanese Kwantung army would put up a strong fight in Manchuria and probably in Korea... that the American troops were having a terrific fight in every island in the Pacific and were having to exterminate all the Japanese defenders; that the Chiefs of Staff were then considering the landing in Japan, where there were supposed to be two and a half million Japanese troops; and that the United States seemed confronted with the necessity of landing three army corps in three different places with the anticipation of very heavy casualties. 24

The fight which the Japanese were making to hold the Pacific Islands was leaving its impression also on the American commander who was to be in charge of the invasion of the Japanese home islands, Genera1 Douglas MacArthur. At the conclusion of the Japanese war, and at the time of the surrender, he said, "nearly everywhere Japanese soldiers had refused to give up until killed; the usual laws of war had not been complied with; deadly traps had frequently been set." 25

January 22, 1945, prior to the Yalta Conference, the United States Chiefs of Staff had prepared a memorandum for the President stating their plan of operations for the defeat of Japan. The agreed over-all objec-

tives in the war were expressed as follows:

To force the unconditional surrender of Japan by:

1. Lowering Japanese ability and will to resist by establishing sea and air blockades, conducting intensive air bombardment, and destroying Japanese air and naval strength;

2. Invading and seizing objectives in the industrial heart of Japan.

The United States Chief of Staff adopted the following as a basis for planning in the war against Japan. The concept of operations for the main effort in the Pacific was to be: 
a. Following the Okinawa operation, to seize additional positions to intensify the blockade and air bombardment of Japan in order to create a situation favorable to:

b. An assault of Kyushu for the purposes of further reducing Japanese capabilities by containing and destroying major enemy forces and further intensifying the blockage and air bombardment in order to establish a tactical condition favorable to:

c. A decisive invasion ${ }_{26}$ of the industrial heart of Japan through the Tokyo plain.

Plans were definitely being formulated to implement the intensified sea and air blockade by November 1, 1945, at which time the southern island of Kyushu was to be invaded, followed in turn by an invasion of the main island of Honshu, the Tokyo Plain referred to in the plan of operations, in the spring of 1946. 27 A report submitted to President Roosevelt on February 9, the fifth day of the conference, stated that the Chiefs of Staff "recommend that the planning date for the end of the war against Japan should be set at eighteen months after the defeat of Germany."28

The total United States military and naval forces involved in these plans were of the order of 5,000,000 men; if all those indirectly concerned were included, it was larger still. 29

The plans provided for a three-pronged assault of southern Kyushu by the United States Sixth Arny. The second phase of the Japanese invasion, to be carried out in the early spring of 1946 , involved the Eighth and Tenth Armies. They were to assault the Tokyo Plain of eastern Honshu. These two veteran Pacific armies were to be followed ashore by armies redeployed from Europe. 30

July, 1945, intelligence reports of the United States War

Department General Staff estimated Japanese military strength as follows: In the home islands, s11ght1y under 2,000,000; in Korea, Manchuria, China proper, and Formosa, slightly over 2,000,000; In French Indo-China, 
Thalland, and Burma, over 200,000; in the East Indies area, including the Philippines, over 500,000; in the by-passed Pacific islands, over. 100,000. The total strength of the Japanese army was estimated at about $5,000,000$ men. 31 There could not have been any fewer available troops in February, at the time of the Yalta Conference.

Secretary of War Stims on believed that,

there was as yet no indication of any weakening in the Japanese determinination to fight rather than accept unconditional surrender. If she should persist $32^{n}$ her fight to the end, she had still a great military force.

As early as the Quebec Conference of August 11-24, 1943, it was recognized that Russia's ald in the Pacific war would be invaluable. Harry Hopkins, special aide to the President, had with him a document headed "Russia's Position," which was described as a "very high level United States military strategic estimate," but not otherwise identified. It contained the following statements:

...the most important factor the United States has to consider in relation to Russia is the prosecution of the war in the Pacific. With Russia as an ally in the war against Japan, the war can be terminated in less time and at less expense of iffe and resources than if the reverse were the case. Should the war in the Pacific have to be carried on with an unfriendly or a negative attitude on the part of Russia, the difficulties will be Immeasurably increased and operations might become abortive. 33

This opinion by mllitary leaders had not changed by the time of the Yalta Conference, and it must be remembered that in a11 considerattons of Far Eastern matters at the conference, Roosevelt's principal concern was based on American war plans against Japan. ${ }^{34}$ The problem would be, in dealing with the Soviet Union, to formulate plans compatible with traditional American policy toward China. Secretary of State Edward Stetinius believed this strongly. He said that, 
"Military considerations of the highest order dictated the President's signing of the Far Eastern Agreement. The military insisted the Soviet Union had to be brought into the Japanese war." 35

General MacArthur expressed his feelings on this subject to Secretary of the Navy Forrestal as follows:

...the help of the Chinese would be negligible. He [MacArthur] felt that we should secure the commitment of the Russians to active and vigorous prosecution of a campaign against the Japanese in Manchukuo of such proportions as to pin down a very large part of the Japanese army; that once this campaign was engaged we should then launch an attack on the home islands.... He felt that our strength should be reserved for use in the Japanese mainland, on the plains of Tokyo, and that this could not be done without the assurance that the Japanese would be heavily engaged by the Russians in Manchuria. He expressed doubt that the use of anything less than sixty divisions by the Russians would be sufficient. 36

There could be little doubt that this remained the belief of the military, and that pressure was applied to Roosevelt consistent with this desire. The report prepared by the United States Joint Staff planners, as of January 18, 1945, expressed this belief and included the following:

b. We should:

(1) State the basic principles as to Russian entry into the war against Japan as follows:

(a) Basic principles regarding our policy toward Russia's entry into the war against Japan are:

1) we desire Russian entry at the earliest possible date consistent with her ability to engage in offensive operations and are prepared to offer the maximum support possible without prejudice to our main effort against Japan.

11) We consider that the mission of Russian Far Eastern forces should be to conduct an all-out offensive against Manchurla to contain Japanese forces and resources in North China and Manchuria that might otherwise be employed in the defense of Japan; to conduct in conjunction with United States strategic air operations 
against Japan proper; and to interdict lines of communica$t$ ion between Japan and the mainland of Asia 37

The War Department had expressed similar beliefs, consistent with those of the Chiefs of Staff. Certainly reason enough for the United States to try to gain all the help possible.

There were those who dissented from this view of the necessity of having to have Russia's help against Japan. They were sure that the air and sea blockade and the air bombardments would soon force Japan to surrender, and that thereafter the Japanese armies in Asta would not long be able to sustain their resistance. Fleet Admiral Earnest King and Admiral William Leahy were the most outspoken in expression of this belief, with Leahy stating that,

By the end of September, 1944, Japan was almost defeated through a practically complete sea and air blockade. I believe that a completely blockaded Japan would fall by its own weight. 38

At the Yalta Conference, Leahy said further,

I was of the firm opinion that our war against Japan had progressed to the point where their defeat was only a matter of time and attrition. Therefore, we did not need Stalin's help to defeat our enemy in the Pacific. 39

But the Army and the Chiefs of Staff felt it essential to plan against the worst possibility. 40 It was furthermore believed that the Japanese troops on the mainland were considered to be "the cream of the Japanese Army. $" 41$

The atomic bomb was also an unknown quantity at this time. Even though a bomber group was being trained to fly the mission of the atomic bomb, it was not to be tested unt1l July 16, 1945, and the military was certainly not going to base their plans on a weapon of which they had little knowledge, and even less comprehension. 
Far East Negotiations and Agreements

Moscow's pledge to join the Allies in the war against the Japanese. had already been made by Stalin to Ambassador $W_{0}$ Averell Harriman, in August of 1942,42 and to Secretary of State Cordell Hull in Moscow, in October, 1943,43 and reaffined by Stalin at the Tehran Conference. Little more was said of this until October, 1944, when Ambassador Harriman and General John $R_{0}$. Deane, of the United States Military Mission in the Soviet Union, had an opportunity to present and discuss 1deas with Stalin during Churchill's visit to Moscow at that time.

Harriman had presented a list of strategic objectives, drawn up by General Deane, and approved by United States Chiefs of Staff; of the part they wished the Soviet Union to play in the war against Japan:

1) Securing the Tran-Siberian railroad and the Vladivostok peninsula; 2) Setting up Soviet and American strategic air forces for operations against Japan from the Maritime Provinces; 3) Securing the Pacific supply route in which Russian participation would include: a) Making Petropavlovsk available to the United States as a naval base. b) Neutralization by air of Southern Sakhalin and Hokkaido. c) Improvement of port facilities of the Amur River. d) Military occupation of Southern Sakhalin. e) Soviet-American naval cooperation as the situation dictated. f) Defeat of the Japanese Army in Manchuria. 44

General Deane reported that Stalin had concurred with these objectives, except Stalin "thought the objectives we [the United States] envisioned were limited too much to Manchuria." Stalin then outlined far more extensive operations, covering a larger area than was expected by the United States Chiefs of Staff. 45

Stalin also informed Harriman, at that time, that there would be certain political considerations to be taken into account; however, he. did not go into any detail during that meeting. These political 
considerations were not pursued further until December, when Harriman again approached Stalin to find out what considerations he desired before entering the war against Japan. In a report to President Roosevelt, on December 15, 1944, Ambassador Harriman sald, upon requesting a clarification of political questions, that Stalin had gone into the next room and brought out a map.

1) He said that the Kurile Islands and the lower Sakhalin should be returned to Russia. He explained that the Japanese now controlled the approaches to Vladivostok, that we consider that the Russians were entitled to protection for their communications to this important post and that 'al1 outlets to the Pacific were now held or blocked by the enemy.'

2) He drew a line around the southern part of the Liaotung Peninsula included Port Arthur and Dairen saying that the Russians wished again to lease these ports and the surrounding area.

3) Stalin said further that he wished to lease the ChineseEastern Railway. The line from Dairen to Harbin thence northward to Manchuli and east to Vladivostok. He specifically reaffirmed that he did not intend to interfere with the sovereignty of China in Manchuria.

4) He sald the only consideration he had not mentioned at Tehran was the $6_{6}$ recognition of the Outer-Mongolia as an independent identity.

It is clear from this that the Russian political conditions for entry into the war aginst Japan were no surprise to President Roosevelt and his advisers at Ya1ta.

No aspect of the Yalta negotiations reflected the dominance of Roosevelt's personal diplomacy as clearly as did the Far Eastern polltical discussions. Most of the discussions were "top-level conferences" between Stalin and Roosevelt, and "most of the American delegates present knew nothing about these discussions, nor was the question raised at the plenary sessions of the Big. Three or at the foreign ministers' meetings. "47 
It was not, however, until the fifth day of the conference, February 8 , that Roosevelt and Stalin first discussed the Soviet political conditions of their entry into the war against Japan, at the concluston of which Stalin suggested that before leaving Yalta these conditions should be put down in writing, and they should contain the statement, "the Heads of the Three Great Powers have agreed that these clalms of the Soviet Union shall be unquestionably fulfilled after Japan has been defeated."48 The President indicated that he thought this could be done.

Two days later, February 10, Molotov, Soviet Foreign Minister, gave to Harriman a memo with the heading, "Draft of Marshal Stalin's political conditions for Russia's entry in the war against Japan。" This document read as follows:

The leaders of the Three Great Powers - the Soviet Union, the United States of America, and Great Britain - have agreed that in two or three months after Germany has surrendered and the war in Europe has ended the Soviet Union shall enter into the war against Japan on the side of the Allies on the condition that:

(1) The status quo in Outer-Mongolia (The Mongolian People's Republic) should be preserved;

(2) The former rights of Russia violated by the treacherous attack of Japan in 1904 should be restored viz:

(a) The southern part of Sakhalin as well as all the islands adjacent to this part of Sakhalin should be restored to the Soviet Union,

(b) Possession of Port Arthur and Dairen on lease should be restored,

(c) The rights possessed by Russia before the RussoJapanese War to the operation of the Chinese-Eastern Railroad and the South-Manchurian Rallroad providing an outlet to Dairen should be restored on the understanding that China should continue to possess full sovereignty. In Manchuria; 
(3) The Kurile Islands should be handed over to the Soviet Union.

The Heads of the three Great Powers have agreed that these claims of the Soviet Union should be unquestionably satisfied after Japan has been defeated.

For its part the Soviet Union expresses its willingness to conclude with the National Government of China a pact of friendship and alliance between the U.S.S.R. and China in order to render assistance to China with its armed forces for the purpose of liberating China from the Japanese Yoke. 49

In presenting these conditions stalin relled on a very persuasive argument, at least to the Americans:

Stalin said to Roosevelt that if his conditions were not met It would be very difficult to explain to the Russian people why they must go to war against Japan. He said that the Russian people clearly understood that they must fight the German people to defend the very existence of their homeland, but that they could see no such threat from the Japanese. However, Stalin said, if the required political conditions were met, then it would not be difficult for him to explain to the Supreme Soviet and the people just what was their stake in the Far Eastern war. 50

Clearly stalin's memo and arguments contained features that were highly favorable to the Soviet Union. The Soviet claims were clearly outlined and justified by historical precedent. And it sought to obligate the United States and Great Britain to support the Soviet claims unconditionally, with no mention of China having to verify them.

When Roosevelt and Stalin had first discussed the agreements there had seemed to be little doubt that the details could be worked out. Stalin had explained what he wanted, the President discussed these matters briefly (Leahy was to say later that "the entire matter consumed relatively very little time"). 51 and made a remark to the effect that he would like to have Chiang Kai-shek's views before dealing with Mongolia, but that he was prepared to discuss the other points. For, though he had not discussed these exact matters with Chiang, Harriman was to say later that Roosevelt had "already had certain genezal talks 
with Chiang on some of the points involved, and knew of Chiang's desire to come to a permanent understanding with the Soviet Union." 52 The President had also remarked that it was hard to discuss matters with the Chinese as anything told them was known to the whole world in twentyfour hours. Stalin was to continue on as if this did not really matter and stated, as mentioned above, that he would like to have the agreements in writing before the end of the conference.

Two days later Molotov presented the Soviet draft of the agreements to Harriman. Upon receiving the memo Harriman said at once that he thought the President would object to three points in the draft:

1. That Port Arthur and Dairen should be international free ports and not Soviet leaseholds.

2. That an alternative arrangement for the Manchurian railways should be specified - joint operations by a Chinese-Soviet commission.

3. That he was sure the President would not wish to dispose finally of these two matters in which China was interested without the concurrence of the Generalissimo. 53

Harriman reported to the President and agreements were worked out concerning the three proposals. The proposals were returned to Molotov the same afternoon, February 10.

Later that afternoon Stalin met with Churchill. Churchill asked him about Russian wishes in the Far East. Stalin said that the Soviet Union wanted a naval base, such as Port Arthur. Churchill knew the Americans would prefer the ports to be under international control, but the Russians wanted to have their interests safeguarded, and replied "we [British] would welcome the appearance of Russian ships in the Pacific, and were in favor of Russia's losses in the Russo-Japanese War being made good." 54 Knowing that he had Churchil1's support and thus assured, Stalin told Roosevelt he was not satisfied and another compromise 
had to be worked out. Further discussions between Stalin and President Roosevelt decided that Dairen would be a free port under international. control, but that Port Arthur was to be a Russian naval base, thus requiring a lease. Stalin, in turn, agreed that it would be more appropriate for the Manchurian rallways to be operated by a ChineseSoviet Commission. And he also agreed on the need for getting Chiang's concurrence with regard to the ports and rallways. Stalin also added that he thought the Generalissimo should also give his concurrence to the status quo in Outer-Mongolia. 55

The only other discussions concerning the Far Eastern Agreement, concerned how and when Chiang should be told of the accord. It was decided that the President would handle the matter, and that the subject would be discussed with him whenever Stalin was ready to have this done. They agreed that it would remain secret for the time being. 56

The secrecy served several purposes:

1. The military one. If Japan had been sure that the Soviet Unton was going to enter the war, it might have closed the port of Vladivostok. It certainly would have hastened its counter preparations to meet the Soviet attack in Manchuria and Korea. However, had these things occurred, the Japanese retreat from South China probably would have taken place sooner and quicker. Thus secrecy was a necessity and an advantage to the Soviet Union, though not to China.

2. It postponed any possible reaction to the agreement by either the Chinese government or the Chinese Communists.

3. It averted what almost certainly would have been a very active debate within the United States about the terms of the agreement. Such a debate at that time might have impaired the unity of the Allies, not only in the Pacific but in Europe. ${ }^{57}$

President Roosevelt and Stalin decided that Stalin was to write out the revisions of the agreements. When he did, he added two passages that had not been included in the first Soviet draft, and apparently were not discussed. In paragraph 2, part b and $c$, the phrase 
"the pre-eminent Interests of the Soviet Union sha11 be safeguarded," had been added. What exactly this phrase meant and how these interests were to be safeguarded was apparently not discussed. And the seemingly contradictory phrases, "these claims of the Soviet Union shall be unquestionably fulfilled after Japan has been defeated," and, "the agreements concerning Outer-Mongolia and the ports and railroads referred to above, will require concurrence of Generalissimo Chiang Kai-shek," were both included in the final draft.

It is doubtful that these were overlooked by anyone, and their inclusion would seem to indicate that President Roosevelt was certain that Chiang would concur, and thus fulfill the agreement and avoid any problem with the Soviet Union.

As far as is known, no further discussions took place between the three leaders, and the following agreement was signed February 11, 1945, by Marshal Stalin, President Roosevelt, and Prime Minister Churchill:

\section{AGREEMENT REGARDING JAPAN}

The leaders of the three Great Powers - the Soviet Union, the United States of America and Great Britain - have agreed that in two or three months after Germany has surrendered and the war in Europe has terminated, the Soviet Union shall enter into the war against Japan on the side of the Allies on condition that:

1. The status quo in Outer-Mongolia (the Mongolian People's Republic) shall be preserved;

2. The former rights of Russia violated by the treacherous attack of Japan in 1904 shall be restored, viz.;

(a) the southern part of Sakhal in as well as all the island adjacent to it shall be returned to the Soviet Union,

(b) the commercial port of Dairen shall be internationalized, the pre-eminent interests of the Soviet Union 
In this port being safeguarded, and the lease of Port Arthur as a navel base of the U.S.S.R. restored,

(c) the Chinese-Eastern Raflroad and the South-Manchurian Raflroad, which provided an outlet to Dairen, shall be jointly operated by the establishment of a joint Soviet-Chinese Company, it being understood that the pre-eminent interests of the Soviet Union shall be safeguarded and that China shall retain full sovereignty in Manchuria.

3. The Kurile Islands shall be handed over to the Soviet Union.

It is understood that the agreement concerning Outer-Mongolia and the ports and rallroads referred to above will require concurrence of Generalissimo Chiang Kai-shek. The President will take measures in order to obtain this concurrence on advice from Marshal Stalin.

The Heads of the three Great Powers have agreed that these claims of the Soviet. Union shall be unquestionably fulfilled after Japan has been defeated.

For its part the Soviet Union expresses its readiness to conclude with the National Government of China a pact of friendship and alliance between the U.S.S.R. and China in order to render assistance to China with its armed forces for the purpose of liberating China from the Japanese yoke. 58

This agreement was considered a separate accord, not as part of the regular conference business. It was thus not published with the other papers, and was not made known to the public until a year later, In February, 1946.

The Far East Agreement was primarily an agreement between the Soviet Union and the United States, but Great Britain also signed, and with little hesitation. Prime Minister Churchill stated publicly that, "neither I nor Eden took any part in the agreement, that it was primarily an American matter." 59 Yet Stettinius, Secretary of state at Yalta, later told that; "the Prime Minister said he had signed the document in order that Great Britain might stay in the Far East," and that he had, "declared that the whole position of the British Empire 
In the Far East might be at stake." Stettinius continued, stating that, "the Prime Minister added that he had great faith in President Roosevelt and felt that he could rely completely on the President's judgment in this matter." 60 It would seem clear that the British had an interest in this matter, and thus assumed equal responsibility with the United States.

\section{Influencing Factors and Considerations}

Though there were some questions about granting the Soviet Union most of what it desired, it should also be noted that this agreement also limited them in what they could legally do. Roosevelt was less anxious to deny Stalin's demands than to confine him to those he had mentioned. President Roosevelt and the Chlefs of Staff wished to avoid premature Russian entry into the war against Japan which might necessitate American involvement on the mainland of Asia. 61 The President deemed it important to secure Soviet entry in time to facilitate an American Invasion of the Japanese home islands, but, unlike the Chiefs of Staff, his motivation was not exclusively military. He apparently was fully aware of the danger that the Soviet Union might stand by until the United States crushed Japan, at great cost in American lives, and then march Into Manchuria and northern China and establish "Peoples' Republics" in Manchuria and Inner Mongolia. 62 Secretary of State Dean Acheson testified to this same belief at the Far East Hearings in 1951, stating, "the grave danger was that they would really wait until the war was over.... and they would come in and do what they wished."63

There was little question that the Soviet Union would be able to establish themselves in a strong position in the Far East if they desired. Certainly the provision regarding Outer-Mongolia, which had been a 
Chinese province unt11 1911, was not a concession as it had been recognized as autonomous and an area of special interest to Russia since that time, they being desirous to protect the long southern Siberian border. The Briefing Book Papers of the State Department had 1isted among its recommendations, that "we belleve Chins's territorial integrity should be respected including her clalm to sovereign rights over such outlaying territories as Tibet and Outer-Mongolia." The Briefing Book continued on to state that the State Department "would not oppose, however, any agreement respecting those territories reached by a process of amicable negotiations between China and the other interested governments." Because of these recommendations, and traditional American policy toward China, the agreements signed by President Roosevelt did not involve a radical departure from what the United States had previously been trying to accomplish with and for China.

While the other portions of the agreement, those not needing the concurrence of Chiang, are more questionable, from the standpoint of the security of the Soviet Union they were not unreasonable demands. There could be little question from any of the Allies that certain of these concessions, as will be shown, were both vital and necessary to Soviet security in this area.

The Soviets had made it clear that they would take Southern Sakhalin unassisted by the United States. 64 As the United States military was agreeable, they would have undoubtedly been in a strong position to demand acquisition of that territory, even if no agreement had been made regarding $1 t$.

Soverelgnty over Sakhalin had long been a source of friction between Russia and Japan. In 1875, Japan had given up all claims to 
Sakhalin in exchange for full title to the Kurile Islands. However, by the treaty of Portsmouth, 1905, Japan was granted that portion of Sakhalin south of the fifty degrees parallel. Since that time Japan had retained control of the southern portion, and for a time in the twenties they had also occupied northern Sakhalin. In March of 1944, during the war, Russia and Japan had signed a treaty whereby Japanese operation of its concessions, gained earlier, in northern Sakhalin ceased, and Japanese fishing rights were restricted.

This last agreement, of 1944, did not help Sino-Soviet relations. The Chinese were highly suspicious of this, as they took it to preclude the possibility that the two powers had agreed not to go to war against one another. The United States was able to convince Chiang that this was not the case, and that he must make an effort to get along with the Soviet Union for the sake of the war effort. 65

It was noted in a State Department Briefing Book study, prepared prior to the Yalta Conference, that the Japanese character of the population of Southern Sakhlin, its close economic integration with Japan proper, and 1ts unquestionable strategic value if Japan was disarmed, would seem to be logical reasons for its retention by Japan, but that political factors might make such a solution impossible。 66

Opposed to this view was the knowledge that it was also of unquestioned strategic importance to the Soviet Union, Sakhalin lay across the most direct airline to Shanghai and Singapore from San Francisco via Dutch Harbor, Petropavlovsk and Vladivostok. It commands the approaches from the northeast to the Japan Sea, the Maritime Provinces and the Soviet Union and Vladivostok.

With these factors in mind, the United States Department of 
Territorial Studies had made the following recommendations:

It is recommended that:

1) If the Soviet Union demands the retrocession of Karafuto (Japanese Sakhalin) efther (a) as a prerequisite to the Soviet Union's entering the war against Japan, or (b) having entered the war against Japan, as a recompense for the Soviet Union's military contribution, the United States should endeavor to satisfy the Soviet Union with the promise of United States support at the peace table as a trust area and placed under the authority of the projected international organization with which would appoint the Soviet Union as administering authority.

2) If the Soviet Union in circumstances outlined under 1) is not satisfied with the proposed disposition in paragraph 1 ) or if the Soviet Union makes demands for the retrocession without having entered the war against Japan and without having offered comnitments in regard thereto the position of the United States should depend upon circumstances existing at that time.

3) If the Soviet Union does not press demands for the retrocession of Japanese Karafuto, whether or not it enters the war against Japan, Japanese Karafuto should be retained by Japan as subject to the principles of disarmament to be applied to the whole Japanese Empire and to the following provisions.

(a) the United Nations to be given facilities for civil aviation, (b) La Perouse Strait should continue to be open to international shipping at all times. 67

The Kurile Islands were treated in much the same manner by the Department of Territorial Studies. The basic factors stated by this Department included the following: "The Kurile Islands have strategic Importance to Japan, the Soviet Union and the United States. They also have appreciable economic value for Japan." 68

Russla had withdrawn from the Kuriles in 1875 , in return for Japan's withdrawal from Southern Sakhalin. The Kuriles had been considered to be a part of Japan proper and for administrative purposes they had been under the Hokkaido prefecture. The Kuriles were important strategically to both Japan and the Soviet Union, because they are a connection chain between the two countries, and provide bases for both defense and attack. They are also important to the Soviet Union because 
they form a military screen to the ocean approach to the Okhotsk Sea and the Marftime Provinces.

The 1slands could also prove important to the United States, because they are near the Aleutians, and form part of the land-bridge between Japan and Alaska, and are situated on the great circle route between the United States and Japan. However, it is highly improbable that United States' claims of this nature were even considered, other than perhaps as the possibility for the location of a naval base somewhere in the islands.

The Department of Territorial Studies offered several posstble solutions. They were as follows:

\section{Japan .}

Japan has a strong claim to the southern group of the Kuriles on the basis of nationality, self-determination, geographic propinquity, econcmic need and historic possession.

Japan's claim to the central islands is based almost solely on the grounds of possession. If, as may be assumed, the southern and central islands should be demilitarized and subject for such a period as may appear adequate to a system of military inspection by an international agency, their retention by Japan would appear not to constitute a threat to other states.

To the northern group Japan's claim is based primarily on its need to retain the fishing industry centered on those islands. Ownership of the islands would be more satisfactory to Japan than a grant of fishing rights in territory under control of one or more other powers. However, whatever disposition may be made of the Kuriles, Japan might be permitted to continue to carry on its fishing industry throughout the islands.

\section{The Soviet Union.}

The Soviet Union has a substantial claim to the northern group, Shimushu, Paramushiro and Aratto, on the grounds of propinquity and the consequent desirability of controlling these islands to prevent them from becoming a military menace if in the possession of a hostile power.

The Soviet government may ask not only for the northern islands but also for the central and possibly even for the southern group. Possession of the northern and central islands would give the Soviet Union control of the passages into the Okhotsk Sea 
which are practically ice-free throughout the year. There would seem, however, to be few factors which would justify a Soviet claim to the Southern islands; this transfer to the Soviet Union would create a situation which a future Japan would find difficult to accept as a permanent solution. It would deprive Japan of 18 lands which are historically and ethnically Japanese and of waters which are valuable for fishing. If the southern islands should be fortified they would be a continuing menace to Japan.

The situation may be complicated by a Soviet demand that the other United Nations agree to the transfer to the Soviet Union of the northern group or of both the northern and central groups as a quid pro quo for the Soviet Union's entering the war against Japan.

\section{The United States.}

The United States Navy wishes a base on the Kuriles which it might use in case of naval operations in this area. It is not clear whether such a base would be under international administration or whether it would be a Russian base open to American ships and planes under designated conditions.

4. The Projected International Orgainzation.

The northern group or both the northern and central groups might be placed under the authority of the projected international organization. This solution would almost completely remove the military menace from their use by any one power. It would also make possible the establishment on the northern group, which is of particular strategic importance, of an international base or bases.

The international organization might designate as administering authority either an international mixed comission, or more likely the Soviet Union. In the latter case, the Soviet Union would doubtless establish the base or bases which, it is hoped would be available for the use of the United States and other United Nations.

It would appear undesirable for the United States to be sole administrator of these islands or to have sole possession of bases, since it would place this country in a distant and dangerous position in case of future difficulties with the Soviet Union.

If the northern and central groups should be placed under the projected international organization rather than given to the Soviet Union in full sovereignty it would be more likely that Japan might obtain the right to continue to carry on the fishing industry in and around the northern islands, and important factor in Japan's economy; and, it would be easier to obtain general American support for the recommendations that Japan's Mandated Islands and Marcus Islands be placed under the authority of the projected international organization and administered by the United States. 
It was noted, but reasons were not given, in The Conferences at Ma1ta and Yalta papers that these two studies, on the Kurile Islands and Southern Sakhalin, were not included in the Yalta Conference BrifIng Papers that were taken to Yalta, and it is not known if President Roosevelt saw these prior to leaving for the conference. In any case, the discussions did not go into this much detail, and there does not seem to be any indication that there was any discussion concerning either making separate agreements - such as dividing the island - or disignating them to be placed under control of the projected international organization.

The requests for, and discussions concerning, Port Arthur and Dairen, and the railways, were viewed in a different light than were the Kurile Islands and Southern Sakhalin. The Soviet Union had formerly had the rights of joint use of the railways and leases for the Ports Arthur and Dairen, granted them in treaties with China in 1896, and 1898, until turned over to the Japanese in the Treaty of Portsmouth, in 1905. Stalin had desired that the ports be leased directly to them, as had been done prior to 1905, and that the rights possessed by them prior to the RussoJapanese War should be restored in their entirety.

Roosevelt was able to turn these demands aside partially, and a compromise was worked out. Harriman had observed in December of 1944 , that "there is no doubt that with control of the railroad operations and with the probability of Russian troops to protect the railroad, Soviet influence will be great" 70 That this would probably prove true seemed to have little to do with the situation, and the agreements were signed. The agreements did include the provision that Chiang was to concur with these agreements, at Roosevelt's insistence, as Stalin had originally 
Intended no such provision, in order that the agreements be fulfilled, but again this would have seemed to do little to lessen the probablity of Soviet influence in Manchuria.

When first discussing the ports, the President had suggested that arrangements might be made in either one of two ways: the ports might be made into free ports with some form of international control, or they might be leased outright to the Soviet Union. Of the two, the President was said to have preferred the free port arrangement. 71 As it worked out, the President was able to gain a compromise on Dairen, whereby Stalin gained his wish with Port Arthur. The President mentioned to Stalin at Tehran the possibility of a free port in the Far East, with Dairen as a possibility, 72 and was able to successfully follow this Idea through at Yalta. However, there had been no mention of Port Arthur at Tehran.

A Briefing Book had been prepared by the State Department concerning Korea, but no written agreements were signed regarding this area. Discussions had been held prior to Yalta, at the Cairo Conference. At Yalta provisional understanding was reached whereby in due course Korea would become a free and independent nation, but that in the meantime a trusteeship would be established to prepare the people for selfgovernment. It was also decided that no foreign troops would be stationed in Korea. ${ }^{73}$ But beyond that no final or definite plans were decided upon. Plans that perhaps could have prevented the Korean conflict of the early 1950's. The Cairo Declaration had contained the statement, "The aforesaid three Great Powers, mindful of the enslavement of the people of Korea, are determined that in due course Korea shall become free and independent." 74 But, this did not constitute any concrete plan. 
State Department planners had recommended that an agreement could and should be reached whereby in due course, as in the Cairo Declaration, Korea would become free and independent, and that an interim international administration or trusteeship should be established until such time as self-government would be possible. It was further stated that, 'Military occupation in Korea by any single state alone, might have far-reaching political consequences," and that,

with the completion of military operation in Korea, there should be, so far as possible, Allied representation in the army of occupation and in military government in Korea, and that such military government should be organized on the principal of centralized administration, with all of Korea administered as a single unit and not as separate zones。 75

No such agreements were reached, and the results were clearly evident in the following years.

It was quite clear to some that President Roosevelt had been prepared, prior to Yalta, and even before the Tehran Conference, to agree to the legitimacy of most, if not all, of the Soviet claims in the Far East, as they involved the restoration of possessions and privileges taken by the Japanese from the Russians in the Russo-Japanese war. 76 Secretary of State Stettinius was told by Harry Hopkins in the days just before the conference, "that good headway had already been made on the question." Stettinius was later to state that the "Far Eastern agreement was carefully worked out and was not a snap decision made at Yalta."77

If this was true, and it certainly seemed to be, then the agreements need no explanation as to why the President did not follow the State Department recommendations, or spend more time discussing the agreements. At the conference, Stettinius, upon hearing of the Far 
Eastern discussions, asked the President, "whether or not there was anything in connection with this matter that he wished the State Department delegation to pursue." The President answered that,

since it was primarily a military matter and since Mr. Harriman had had many private discussions about it with him and with representatives of the Soviet Union over a period of time, he thought it had best remain on a purely military level, 78

though it clearly was not intended to be only a military matter. It was also clear that Roosevelt intended to handle his own diplomacy, as had often been the case in the past, and not involve the State Department. President Roosevelt sought at the Yalta Conference to reduce the general assurances which stalin had previously given, to specific undertaking for the early entry of Russia in the Pacific war. He further wanted to limit Soviet expansion in the East and to gain Soviet support for the Nationalist Government of China. ${ }^{79}$ With the signing of the Far East Agreement, Rooseve1t, and others, thought they had accomplished these goals. 
CHAPTER IV

\author{
SINO-SOVIET NEGOTIATIONS \\ AND \\ AGREEMENTS
}

\title{
Sino-Soviet Opening Negotiations
}

On June 15, 1945, Ambassador Hurley informed Chiang of the provisions of the Yalta Agreement, pursuant to instructions from President Harry Truman of June 9, 1945 (President Roosevelt having died Apri1 12, 1945). Following talks with Dr. T. V. Soong, Chinese Foreign Minister, President Truman had cabled the following message to Ambassador Hurley:

You are aware of an agreement made in February that the President would take measures to obtain from Chiang Kai-shek his concurrence in the understanding of the Soviet Government stated herewith following.

Stalin wishes to discuss his proposals directly with Soong in Moscow before the first of July.

1. Stalin has made to us a categorical statement that he will do everything he can to promote unification under the leadership of Chiang Kai-shek.

2. That this leadership would continue after the war.

3. That he wants a unified stable China and wants China to control all of Manchuria as a part of a United China.

4. That he has no territorial claims against China, and that he will respect Chinese sovereignty in all areas his troops enter to fight the Japanese.

5. That he will welcome representatives of the Generalissimo to be with his troops in Manchuria in order to facilitate the organization of Chinese administration in Manchuria.

6. That he agrees with America's "open door" policy in China. 
7. That he agrees to a trusteeship for Korea under China, Great Britain, the Soviet Union, and the United States.

The conditions for Soviet participation in the war against Japan are as follows, and if these conditions are met, a Soviet attack will be made in August:

[The Text of the Far East Agreements as signed at Yalta was included in the message at this point.]

Inform Chiang Kai-shek that President Roosevelt agreed to support these Soviet claims upon the entry of Russia in the war against Japan. I am also in agreement.

T. V. Soong has been given this information.

You are hereby directed to take up this matter with Chiang on June fifteenth and to make every effort to obtain his approval. 1

Chiang Kai-shek had long been desirous of formulating a series of agreements with the Soviet Union to protect China's interests in Manchuria and the border area, and to reach agreements concerning the Chinese Communists. He would now have the opportunity to negotiate for these agreements.

Dr. T. V. Soong, who had learned of the Yalta Agreement from President Truman just prior to the time Chiang was informed in Chungking, was sent to negotiate with the Soviet Government, after reviewing the agreements with Chiang and Ambassador Hurley. If the Soviet negotiations would follow the pattern of understandings as Truman cabled them to Hurley, then China might have been at least partially optimistic on the eve of the coming negotlations. Soong's talks with Stalin and Molotov had begun, with a definite knowledge of impending events, on June 30,1945 . It was known that in about a month, Soviet troops might be coming down through Mongolia and Manchuria into China and Korea, within easy reach of the Chinese Communist zone. 
Harry Hopkin, special alde to the President, talked with Stalin In May, 1945, and had been told that Soviet armies would be in a sufficient state of preparedness and in position by August 8, 1945, to move against the Japanese. However, as to the actual date of operations Stalin felt that would depend on the execution of the agreement made at Yalta concerning Sovfet desires. Stalin said it was necessary to have these agreements in order to justify entry into the Pacific War. ${ }^{2}$

It was also known that Stalin would be meeting with Truman and Churchill in the near future and would be formulating final plans for their entrance into the Pacific War.

At the beginning of the negotiations Stalin, without scruple, demanded rights and privileges in Manchurla that went well beyond any claims revealed before or at the Yalta Conference. The Soviet Union asked (1) for a controlling interest in the Chinese Eastern and South Manchurian Railways; (2) that the boundaries of the Dairen and Port Arthur leases be those of the Kwantung Peninsula lease prior to the Russo-Japanese War of 1904; and (3) the recognition of the independence of Outer-Mongolia. ${ }^{3}$ Stalin had also made it clear that all other questions would have to be settled in advance before the Soviet Union would enter into a pact of friendship with the Chinese Goverment. ${ }^{4}$ ) Soong was then presented with three Soviet prepared drafts of agreements: A Treaty of Friendship and Alliance; An Agreement RegardIng the Ports of Dairen and Port Arthur; An Agreement Regarding the Manchurian Railroads. The first offered Chiang Kal-shek what he so eagerly wanted, but there remained a wide diversfon of opinion between Soviet desires, and what the Chinese were willing to surrender in return for the first agreement. Stalin was also demanding Chinese 
recognition of Outer-Mongolia, another strong point of contention.

Soong's first and immediate concern was for Outer-Mongolia.

Though Stalin was demanding independence for this area, Soong considered it nothing less than a direct cession of territory and was concerned, "that it would complicate the question of Tibet, and that no government of China would last if it ceded Outer-Mongolia."5 Soong later told Harriman,

that this was a matter of principle that was deeply embedded in Chinese psychology, and that although they realized that they could not then exercise sovereignty over Outer-Mongolia the Chinese would be unwilling to support a government which gave up for all time Chinese claims to this territory. 6

Nevertheless, Soong translated these drafts and sent them to Chiang, and received at the same time a message from him which set down the maximum concessions which he thought China ought to be called upon to make. They were far less than what Russia had set down. Ambassador Hurley transmitted these maximum concessions to President Truman, July 7. They were as follows:

China will agree to recognize the independence of the Mongolian People's Republic after the war if the Soviets agree fully to respect the sovereignty and territorial and administrative integrity. The Soviet would be offered the joint use of Port Arthur but not joint control. Dairen will be made a free port but under Chinese administration. The two railroads will be jointly operated, but remain under Chinese ownership and sovereignty. The Soviet agrees not to give any support to the Chinese Communists or to rebellious
elements in Sinkiang....

Negotiations continued along these lines until July 12, at which time Soong told Ambassador Harriamn that he had come to an understandIng of all matters except for some points concerning the railroads and ports. Soong and Stalin had agreed on the recognition of Outer-Mongolia after the war, and Stalin had offered Soong satisfactory conditions for 
the Treaty of Friendship, and they had agreed on civil affairs during the military period in Manchuria, and finally Stalin had assured Soong that he would withhold support from the insurgents in Sinkiang and the Chinese Communists Party。 8

Stalin had given in on such points as agreeing that all guards on the railroad would be Chinese, and that the Soviet Union would not have rights to move troops in Manchuria in peacetime. The final point not agreed to regarding the railroads was control of the management. Stalin wanted a majority of the directors but Soong had resisted. 9 Stalin was also insisting that the military zone which would be under Russian control should include Dairen as well as Port Arthur, and that there should be a naval base within Dairen. Soong offered Port Arthur and the area south of Dairen as a military zone, but maintained Dairen should be a free port under Chinese management, with certain docks and storage yards leased to the Soviets on a commercial basis for their through shipments. 10

The following night Soong met once again with Stalin and Molotov, prepared to outline in detail the maximum concesstons he was authorized to make concerning the railroads and ports. He planned to return to Chungking to consult with Chiang if the meeting did not reach any agreement.

In a telegram to the President and Secretary of State, sent July 13, Ambassador Harriman, who was kept fully informed of the talks by Soong and who reported them to the President, reported the final negotiations, before the Potsdam Conference, as follows:

As to the management of the railroads he [Soong] proposed equal number of directors with Chinese to be Chairman without administrative authority as a courtesy to China; the manager of the 
Chinese Eastern to be Russtan and the Assigtant Manager Chinese; the Manager of the South Manchurian to be Chinese with a Russian as Assistant Manager. He proposed that the port of Dairen should be $a$ free port under Chinese management, but offered the Soviets docks and storage areas under commercial lease for the through traffic. He explained for obvious reasons he could not agree to the port of Dalren or the connecting railroad to be in a Soviet military zone or to be used as a Soviet naval base. Soong offered Port Arthur as a naval base for joint use but under Soviet contro1. There does not appear to be any differences regarding Port Arthur but Stalin told Soong that his proposals regarding the port of Dairen and the rallroads were unsatisfactory. Stalin did not offer any further concessions in his demands for the control of the railroads and for the inclusion of Dairen in the military zone substantially under Soviet control. Soong then said he felt he should return to Chungleing to consult with Chiang, but would be prepared to come to Moscow again at any time Stalin wished. 11

After the meeting with stalin, Soong told Harriman that:

He did not press Stalin further on any point as he was anxious to leave the subjects open in order to obtain your [ President Truman's ] views. He is hopeful that you will be able to get Stalin to accept the Chinese position at the forthcoming conference or that you will be able to work out a compromise wich the Generalissimo can accept. He did not, however, say this to Stalin, although from a political standpoint he feels that china has made a serious concession in agreeing to recognize the independence of Outer Mongolia. He feels that the discussions here have made important progress in the establishment of friendly relations between his government and the Kremlin and is satisfled with the understandings reached on questions other than those st 111 at issue. 12

Harriman reported the following to Truman on the portion of the

talks that concerned Korea:

As to Korea, Stalin confirmed to Soong his agreement to establishing a four power trusteeship. Molotov interjected that this was an unusual arrangement with no parallel and that therefore it would be necessary to come to a detailed understanding. Stalin stated that there should be no foreign troops or foreign policy in Korea, Soong understand's that the Russians have 2 Korean divisions trained in Siberia. He believes that these troops will be left in Korea and that there will be Soviet trained personnel who will also be brought into the country. Under these conditions he is fearful that even with a four power trusteeship the Soviets will obtain domination of Korean affairs.13

Thus, on the eve of the Potsdam Conference, accord was in sight except in regard to the treatment of the Manchurian ports and railways. 
The issue in these cases was, in all reality, who would be in actual control. Stalin stood firm, stating that he wanted to settle these $18 s u e s$ before leaving for Berlin, the insinuation being he wanted them settled before he would enter the war against Japan. Soong was not to be Intimidated and returned to Chungking, and stalin left for the Potsdam Conference.

Soong returned to Chungking and discussed the negotiations with Chlang Kal-shek. On July 19, he sent a message to Harriman, through Hurley, stating that, "I am convinced that we have gone as far as we possibly could in meeting soviet demands."14 on July 20, Chiang sent a message to President Truman, including in the message a letter he had sent to Stalin, stating China's position. Realizing that they were almost at an impasse unless someone proved willing to give in to the other's desires, he appealed to Truman for help, stating,

I trust in your conversation with Generaliss imo Stalin you would impress him on the eminently reasonable stand we have taken, 80 that he will not insist on the impossible."its

Though wishing to see these negotiations concluded, President Truman and Secretary of State Byrnes, who had succeeded Edward Stettinius on July 3 , did not want to become any more involved than they were at the present time, and did not comply with Chiang's request. On July 23, President Truman telegraphed the following message from Berlin to Chiang in Chungking:

I asked that you carry out the Yalta agreement, but I had not asked that you make any concession in excess of that agreement. If you and Generalissimo stalin differ as to the correct interpretation of the Yalta agreement, I hope you will arrange for Soong to return to Moscow and continue, your efforts to reach complete understanding. 16 
Fina1 Negotiations and Agreements

With this thought in mind, Soong and Wang Shih-chieh ${ }^{17}$ returned to Moscow to await Stalins's return from Potsdam. Chiang had decided to give in more to the Soviet exactions. He had authorized Soong to grant the Soviet Union a military zone north of the Rwantung Peninsula to the line of the former Russian Tsarist lease, but excluding Dairen and the connecting rallway. 18

In their first talk, August 7, Stalin had shown that he was determined to have still more: to get under one guise or another control of the port of Dairen, and the route leading into and out of it. To these he had added the demand that China should agree not to fortify any islands for a hundred miles south of Port Arthur. 19

This demand China was determined to reject, and subsequently did. Stalin also raised the question of "war trophies" at this time, Harriman reported, and indicated that some of the Japanese properties, including the shares of some Japanese enterprises, should be considered as Soviet war trophies in areas occupied by the Soviet armies. Soong inquired exactly what Stalin had in mind, but Stalin was evasive on this point and left the matter for future discussion. 20 It ultimately was never brought up for discussion again. However, in light of subsequent events, it should have been, as the Soviet Unfon dismantled and removed virtually all Japanese industries and enterprises in Manchuria, after the war.

The United States intervened in the negotiations at this point when Harriman wrote a note to Molotov and discussed the matter with Stalin. Harriman had been advised by Secretary Brynes, acting on Truman's instructions. Harriman was to tell Stalin, at that time, that the United 
States belleved Soong had already met the Yalta requirements. The United States requested that no agreement be made involving further concessions by China, "particularly with reference to the inclusion of the Port of Dairen In the Soviet military zone, without consultation with us."21 With this ilmited pressure being brought to bear, Stal in compromised, to a limited extent, with Soong, but Harriman reported that Soong's resistance was wearing down. 22

In return for a promise that the Soviet Union would not exercise, In time of peace, military authority in the city, port, or connecting railways, Soong agreed that Dairen might be within the Soviet military zone. Soong gave in somewhat more regarding details of the management of the Manchurian railways. He accepted, after long argument, wording he knew to be not as clear and conclusive as it might be in the Soviet pledge to support the Nationalist Government, and withhold ald from dissident elements in occupied territory, 23

Soong's giving in on these points was undoubtedly closely related to Stalin's announcement, "that the Chinese government had better come to an agreement quickly or the Communists would get into Manchur1a." 24 The fact that the remaining points of difference, settled quickly, were concluded after the Soviet declaration of war on Japan, and their subsequent Invasion of Manchuria, certainly had much to do with China's position.

While the news of the Japanese surrender opread, the final Treaty of Friendship and related agreements were signed, on August 14, 1945, with Molotov signing for the Soviet Union and Wang for the Nationalist Government of China. 
The treaty and corresponding agreements were as follows:

TREATY OF FRIENDSHIP AND ALLIANCE

BETWEEN THE REPUBLIC OF CHINA AND THE U.S.S.R. AUGUST 14,1945

The President of the National Government of the Republic of China and the Presidium of the Supreme Soviet of the U.S.S.R.,

Desirous of strengthening the friendly relations that have always existed between China and the U.S.S.R., through an alliance and good neighborly post-war collaboration,

Determined to assist each other in the struggle against aggression on the part of the enemies of the United Nations in this world war, and to collaborate in the common war against Japan until her unconditional surrender,

Expressing their unswerving aspiration to cooperate in the cause of maintaining peace and security for the benefit of the peoples of both countries and of all the peace-loving nations.

Acting upon the principles enunciated in the joint declaration of the United Nations of January 1, 1942, in the Four Power Declaration 8 igned in Moscow on October 30, 1943, and in the Charter of the International Organization of the United Nations,

Have decided to conclude the present Treaty to this effect and appointed as their plenipotentaries: [ Signatures of the plenipotentiaries followed here]

Who, after exchanging their Fu11 Powers, found in good and due form, have agreed as follows:

\section{ART ICLE I}

The High Contracting Parties undertake in association with the other United Nations to wage war against Japan until final victory is won. The High Contracting Parties undertake mutually to render to one another all necessary military and other assistance and support in this war.

\section{ARTICLE II}

The High Contracting Parties indertake not to enter into separate negotiations with Japan and not to conclude, without mutual consent, any armistice or peace treaty either with the present Japanese Government or with any other government or authority set up in Japan which do not renounce all aggressfve intentions. 


\section{ARTICLE III}

The High Contracting Parties undertake after the termination of the war against Japan to take jointly all measures in their power to render impossible a repetition of aggression and violation of the peace by Japan.

In the event of one of the High Contracting Parties becoming involved in hostilities with Japan in consequence of an attack by the latter against the said Contracting Party, the other High Contracting Party shall at once give to the Contracting Party so involved in hostilities all the military and other support and assistance with the means in its power.

This article shall remain in force until such time as the organization "The United Nations" may on request of the two High ContractIng Parties be charged with the responsibility of preventing further aggression by Japan.

\section{ARTICLE V}

The High Contracting Parties, having regard to the interests of the security and economic development of each of them, agree to work together in close and friendly collaboration after the coming of peace and to act according to the principles of mutual respect for their sovereignty and territorial integrity and of non-interference in the internal affairs of the other Contracting Party.

\section{ARTICLE VI}

The High Contracting Parties agree to render each other very possible economic assistance in the post-war period with a view to facilitating and accelerating reconstruction in both countries and to contributing to the cause of world prosperity.

\section{ARTICLE VII}

Nothing in the treaty shall be so construed as may affect the rights or obligations of the High Contracting Parties as members of the organization "The United Nations."

\section{ARTICLE VIII}

The present Treaty shall be ratified in the shortest possible time. The exchange of the instruments of ratification shall take place as soon as possible in Chungking.

The Treaty comes into force immediately upon its ratification and shall remain in force for a term of thirty years.

If neither of the High Contracting Parties has given notice, a year before the expiration of the term, of its desire to terminate 
the Treaty, it shall remain valid for an unlimited time, each of the High Contracting Parties being able to terminate its operation by giving notice to the effect one year in advance. 25

This Treaty, along with the exchange of notes, as follows, relating to the Treaty, was what Chiang Kai-shek desired, and was w11ling to make concessions to gain.

The exchange of notes relating to the Treaty of Friendship and Alliance, as part of the Agreements were as follows:

The People's Commissar for Foreign Affairs, [Molotov] to the Chinese Minister of Foreign Affairs [Wang] .

Your Excellency, With reference to the Treaty of Friendship and Alliance signed today between the Republic of China and the U.S.S.R., I have the honor to put on record the understanding between the High Contracting Parties as follows:

1. In accordance with the spirit of the aforementioned Treaty, and in order to put into effect its aims and purposes, the Government of the U.S.S.R. agrees to render to China moral support and aid in military supplies to be entirely given to the National Government as the central government of China.

2. In the course of conversations regarding Dairen and Port Arthur and regarding the joint operation of the Chinese Changchun Railway, the Government of the U.S.S.R. regarded the Three Eastern Provinces as part of China and reaffirmed its respect for China's full sovereignty over the Three Eastern Provinces and recognize their territorial and administrative integrity.

3. As for the recent development in Sinkiang the Soviet Government confirms that, as stated in Article $V$ of the Treaty of Friendship and Alliance, it has no intention of interfering in the internal affairs of China.

If your Excellency will be 80 good as to confirm that the understanding is correct as set forth in the preceding paragraphs, the present note and Your Excellency's reply thereto will constitute a part of the aforementioned Treaty of Friendship and Alliance.

The Chinese Minister of Forelgn Affairs [Wang] to the People's Commissar for Foreign Affairs [ Molotov] :

Your Excellency: I have the honour to acknowledge receipt of Your Excellency's Note of today's date reading as follows:

[see Molotov's note above] 
I have the honour to confirm that the understanding is correct as set forth above.

The next exchange of notes referred to Outer-Monglia.

The Chinese Minister for Foreign Affairs [Wang] to the People's Comnissar for Foreign Affairs [Molotov].

Your Excellency: In view of the desire repeatedly expressed by the people of Outer-Mongolia for their independence, the Chinese goverment declares that after the defeat of Japan should a plebiscite. of the Outer-Mongolian people confirm the desire, the Chinese Government with the existing boundary as its boundary.

The above declaration will become binding upon the ratification of the Treaty of Friendship and Alliance between the Republic of China and the U.S.S.R. signed on August 14, 1945.

The People's Commissar for Foreign Affairs [Molotov] to the Chinese Minister for Foreign Affairs [Wang].

Your Excellency: I have the honour to acknowledge receipt of Your Excellency's Note reading as follows: [ see Wang's Note above]

The Soviet Government has duly taken note of the above communication of the Government of the Chinese Republic and hereby expresses its satisfaction therewith, and it further states that the Soviet Government will respect the political independence and territorial integrity of the People's Republic of Mongolia (Outer-Mongolia).26

The above two exchanges of notes concluded that portion of the treaty. The following series of agreements concluded the final negotiations signed August 14, 1945 :

\section{AGREEMENT CONCERNING DAIREN}

In view of a Treaty of Friendship and Alliance having been concluded between the Republic of China and the U.S.S.R。 and of the pledge by the latter that it will respect Chinese sovereignty in the control of all of Manchuria as an integral part of China; and with the object of ensuring that the U.S.S.R.'s interest in Dairen as a port of entry and exit for its goods shall be safeguarded, the Republic of China agrees:

1. To declare Dafren a free port open to the commerce and shipping of all nations.

2. The Chinese government agrees to apportion in the mentioned port for lease to U.S.S.R. warfs and warehouses on the basis of separate agreement. 
3. The Administration of Dafren shall belong to China.

The harbor-master and deputy harbor-master will be appointed by the Chinese Eastern Raflway and South Manchurian Railway in agreement with the Mayor. The deputy harbor-master shail be a Chinese national.

4. In peace time Dairen is not included in the sphere of efficacy of the naval base regulations, determined by the Agreement on Port Arthur of August 14, 1945, and shall be subject to the military supervision or control established in this zone only in case of war against Japan.

5. Goods entering the free port from abroad for through transit to Sovlet territory on the Chinese Eastern and South Manchurian Railways and goods coming from Soviet territory on the said railways into the free port for export shall be free from customs duties. Such goods shall be transported in sealed cars.

Goods entering China from the free port shall pay the Chinese import duties, and goods going out of other parts of China into the free port shall pay the Chinese export duties as long as they continue to be collected.

6. The term of this agreement shall be thirty years and this Agreement shall come into force upon its ratification.

The following Protocol to the Agreement on Dairen is the separate agreement referred to in point two of the above agreement:

\section{PROTOCOL TO THE AGREEMENT ON DAIREN}

1. At the request of the U.S.S.R. the Chinese Government leases to the U.S.S.R. free of charge one half of all port installments and equipment. The term of lease shall be thirty years. The remaining half of port installments and equipment shall be reserved for the use of China.

The expansion or re-equipment of the port shall be made by agreement between China and the U.S.S.R.

2. It is agreed that the sections of the Chinese Changchun Railway running from Dairen to Mukden that 1 le within the region of the Port Arthur naval base, shall not be subject to any military supervision or control established in this region.

\section{AGREEMENT ON PORT ARTHUR}

In conformity with and for the implementation of the Treaty of Friendship and Alliance between the Republic of China and the U.S.S.R., the High Contracting Parties have agreed as follows: 
Article I. With a view to strengthening the security of China and the U.S.S.R. against further aggression by Japan, the Government of the Republic of China agrees to the joint use by the two countries of Port Arthur as a naval base.

Article II. The preclse boundary of the area provided in Article I is described in the Annex and shown in the map [ map not included In this paper]

Article III. The High Contracting Parties agree that Port Arthur; as an exclusive naval base, will be used only by Chinese and Soviet military and commercial vessels.

There shall be established a Sino-Soviet Military Commission to handle the above-mentioned naval base. The Commission shall consist of two Chinese and three Soviet representatives. The Chairman of the Commission shall be appointed by the Soviet side and the Vice-Chairman shall be appointed by the Chinese side.

Article IV. The Chinese Government entrusts to the Soviet Government the defense of the naval base. The Soviet Government may erect at its own expense such installations as are necessary for the defense of the naval base.

Atticle V. The Civil Administration of the whole area will be Chinese. The leading posts of the Civil Administration will be appointed by the Chinese Government taking into account Soviet interests in the area.

The leading posts of the civil administration in the city of Port Arthur are appointed and dismissed by the Chinese Government in agreement with the Soviet military command.

The proposals which the Soviet military commander in that area may address to the Chinese civil administration in order to safeguard security and defense will be fulfilled by the said administration. In cases of disagreement, such cases shall be submitted to the Sino-Soviet military commission for consideration and decision.

Article VI. The Government of the U.S.S.R. have the rights to maintain in region mentioned in Article II, their army, navy, and air force and to determine their location.

Article VII. The Government of the U.S.S.R. also undertakes to establish and keep up lighthouses and other installations and signs of necessary security for navigation of the area.

Article VIII. After the termination of this agreement all the installations and public property installed or constructed by the U.S.S.R. in the area shall revert without compensation to the Chinese Government. 
Article IX. The present agreement is concluded for thirty years. It comes into force on the day of ratification. 27

The appendix to the above Agreement on Port Arthur contained a detalled description of the area to be taken into account in Article II. A map was also included with these agreements. 28

To prove of ultimate importance in the future of Nationalist China were the agreements regarding Soviet troops in the "Three Eastern Provinces" of China, after the entry of these troops into China. Chiang had been extremely worried about the Chinese Communists in areas 1iberated by the Soviet troops. These agreements were as follows:

The President of the National Government of China and the Presidium of the Supreme Council of the Union of Soviet Soclalist. Republics, desirous that relations between the Chinese Administration and the Commander-in-Chief of the Soviet forces after the entry of the Soviet troops into the "Three Eastern Provinces" of China during the present joint military operations against Japan should be governed by the spirit of friendship and alliance existing between the two countries, have agreed on the following:

1. After the Soviet troops enter the "Three Eastern Provinces" of China as a result of military operations, the supreme authority and responsibility in all matters relating to the prosecution of the war will be vested in the zone of operations for the time required for the operations, in the Commander-in-Chief of the Soviet forces.

2. A Chinese National Goverment representative and staff will be appointed for the recovered territory, whose duties will be:

(a) To establish and direct, in accordance with the laws of China, an administration for the territory cleared of the enemy.

(b) To establish the cooperation between the Chinese arwed forces, both regular and irregular, and the Soviet forces in recovered territory.

(b) To ensure the active cooperation of the chinese administration with the Commander-in-Chief of the Soviet forces and, specifically, to give the local authorities directions to this effect, being guided by the requirements, and wishes of the Commander-inchief of the Soviet forces. 
3. To ensure contact between the Commander-in-Chief of the Soviet forces and the Chinese National Government representative a Chinese military mission will be appointed to the Commander-in-Chief of the Soviet forces.

4. In the zones under the supreme authority of the Commander-inChlef of the Soviet forces, the Chinese National Government administration for the recovered territory will maintain contact with the Commander-in-Chief of the Soviet forces through the Chinese National Government representatives.

5. As soon as any port of the liberated territory ceases to be a zone of imnediate military operations, the Chinese National Government will assume full authority in the direction of public affairs and w11l render the Commander-in-Chief of the Soviet forces every assistance and support through its civil and military forces.

6. All persons belonging to the Soviet forces on Chinese territory will be under the jurisdiction of the Commander-in-Chief of the Soviet forces. A11 Chinese, whether civilian or military, will be under Chinese jurisdiction. This jurisdiction will also extend to the civilian population on Chinese territory even in the case of offenses against the Soviet armed forces, with the exception of offenses committed in the zone of military operations under the furisdiction of the Commander-in-Chief of the Soviet forces, such cases coming under the jurisdiction of the Commander-in-Chief of the Soviet forces.

7. With regard to currency matters after the entry of Soviet troops into the "Three Eastern Provinces" of China, a separate agreement shall be reached.

8. The present Agreement comes into force immediately upon the ratification of the Treaty of Friendship and Alliance between China and the U.S.S.R. signed this day. 29

The last of the agreements concerned the Chinese Changchun Railway and has proved to be one of the strongest focal points of present-day criticism. The final agreement was as follows:

Article I. After the Japanese armed forces are driven out of the Three Eastern Provinces of China the main trunk line of the Chinese Eastern Railway and the South Manchurian Railway from Manchuli to Suifenho and from Harbin to Dairen and Port Arthur united into one railway under the name "Chinese Railway" shall be in joint ownership of the U.S.S.R. and the Republic of China and shall be operated by them jointly.

There shall be joint ownership and operation only of those lands acquired and railway auxilary ines built by the Chinese Eastern Rallway during the time of Russian and joint Sino-Soviet Adminfstration and by the South Manchurian Railway during the time of Russian administration and which are designed for direct needs of the railways as well as the subsidiary enterprises built during the said periods and directly serving these railways. All 
other railway branches, subsidiary enterprises and lands shall be in the complete ownership of the Chinese Government.

The foint operation of the aforementloned rallway shall be undertaken by a single management under Chinese sovereignty and as a purely commercial transportation enterprise.

Article II. The High Contracting Parties agree that their joint ownership in the railway shall be in equal shares and shall not be alienable in whole or in part.

Articles III through VIII concerned the administration of the railway and how it should be organized.

Article IX. The Chinese Government will bear the responsibility for the protection of the said Railway....

Article $x$. Only during the time of war against Japan may the railway be used for the transportation of Soviet troops. The Soviet Government has the right to transport by the above-mentioned railway for transit purposes military goods in sealed cars without customs inspection.

The remaining Articles, XI through XVIII, concerned administration and clarifying aspects of the joint ownership, Article XVII did state that the terms were to be for thirty years, at which time the Chinese Changchun Rallway, with all its properties, was to be transferred, without compensation, to the ownership of the Republic of China 30

The Role of the United States in the Sino-Soviet Negotiations

After President Truman received word from Hopkins that Stalin was now ready to talk to the Chinese, he talked with Soong on the 9 th, and on the $14 \mathrm{th}$, and repeated to him the results of the Hopkins-Stalin visit at the end of May, 1945, concerning the Yalta Agreement and the Far East. Soong expressed his gratification, and pointed out that, even though the Yalta Agreement referred of the re-establishment of Russian rights lost In the Russo-Japanese War of 1904, by the Sino-Soviet Treaty and related 
agreements of May 31, 1924, and the agreement of September 30, 1924, Russia had renounced special concessions, including extra-territoriality. He said these points would have to be clarifled. 31

On June 15, 1945, Ambassador Hurley informed Chiang Kai-shek, as mentioned previously, of the provisions of the Yalta Agreement, pursuant to instruction from President Truman on June 9, 1945. At the same time the Ambassador communicated to him Marshal Stalin's categorical assurances regarding Chinese sovereignty in Manchuria, and his oral concurrence to the principle of the Open Door in China, both of which Stalin had given to the President via Harry Hopkins. ${ }^{32}$

Chiang Kaf-shek immediately offered three suggestions concerning what Hurley was discussing with him:

1. That the United States and Great Britain should become parties to whatever agreement China might sign with the Soviet Union. This, he said, would make it more certain that the Soviet Union would comply with its terms.

2. That Port Arthur should be designated as a joint naval base, for four powers: China, Soviet Union, United States, and Great Britain.

3. That the transfer of Sakhalin and the Kuriles to the Soviet Union should be discussed by the same four powers rather than by China and the Soviet Union alone.

However, Hurley made it plain to Chiang that the United States Government would not become a cosponsor. Hurley was told to tell Chiang that the American Government could not consent either to share in the joint use of Port Arthur as a naval base or to become a party to whatever agreement the Chinese govermment might decide to sign with the Soviet Union. He was also told that it seemed very doubtful whether the Soviet Union would consent to the arrangement that Chiang had in mind, since the purpose of the pact with China would be regulating sino-Soviet relations. 34 
Hurley reviewed with Soong his mission as envoy to Stalin and repeated, in a talk with Chiang and Soong on June 22, that President Truman approved and supported the Yalta decision even though the United States had declined to become cosponsors of any agreements between China and the Soviet Union.

Soong, after one of the first talks with Stalin, had tried to quiz the American Government about the intended meaning of parts of the agreement which Roosevelt had signed at Yalta. Byrnes, who had just succeeded Stettinius as Secretary of State, answered through Harriman. Byrnes' position was that both he and the President thought it was unwise for the United States Govermment to act as interpreter. However, Byrnes told Harriman that he could "informally" confide to Soong his understanding that in so far as the United States was concerned, there was no discussion of interpretation of the wording of the Yalta decision relating to the status quo of Outer-Mongolia, and that in the absence of such discussion the accepted meaning of the words as written should be that the present factual and juridicial status quo of Outer-Mongolia was to be preserved. 35 Byrnes further believed that he understood that the railways should be jointly owned and operated by the Soviet Union and China, and that while the United States Government did not wish to share in the control of administration of the port of Dairen, it would expect to have free and equal access to the ports as well as to the railways. 36 Ambassador Harriman also told both the Soviet Government and Soong that the American Government expected to be consulted before any agreement was finally made. 37 ,

Harriman reported to the President and Secretary of State, on July 9, that 1t seemed doubtful that Soong would be success ful in reaching 
agreement with Stalin. He recommended that immediate steps be taken

to prepare, for'use at Berlin, a study of American interpretations of

the Yalta Agreement,

specifically the terms which we believe China should grant the Soviet Government in regard to the ports and rallroads and what action should be expected of China at this time, in coppection with preservation of the status quo in Outer-Mongolia. 38

He further recommended that President Truman should discuss the issues with Stalin when they met at Potsdam.

Following Harriman's recommendation, the State Department pre-

pared a document clarifying the United States position in regard to

the Yalta Agreement, made such recommendations as they thought necessary,

and reached the following conclusions:

.... It would thus appear that while de jure China has sovereignty over Outer-Mongolia, de facto sovereignty has not been exercised since 1911 .

If the future status of Outer-Mongolia is decided on the basis of self-determination of peoples, then there is little doubt that that territory would separate itself from China, and as an independent nation or otherwise, enter the Soviet orbit. Mongolians have been traditionally antipathetic to the Chinese, and, so far as can be judged, have been willing adherents to the Soviet ideologies and influence. In light of realities of the situation, it is believed that the Chinese Government would be well advised to give formal recognition to a situation which has long existed in fact and at the same time endeavor to capitalize upon the good-will of the Soviet Union thereby gained to obtain firm comitments from the Soviet Government which will confirm and strengthen the Chinese position in Inner Mongolia and Manchuria....

....The provisions are clearly more advantageous to China than would be terms calling for the complete restoration of the rights possessed by Russia in Manchuria prior to the Russo-Japanese war... [however] the provisions of the proposed agreements are less advantageous to China than would be terms based upon a nomal construction taken by themselves....

There is an undoubted inconsistency between Soviet commitments to respect Chinese sovereignty and proposals under which for even a limited period of years Russia would exercise virtual control over the main railways of Manchuria and en joy predominant administrative rights and exclusive administrative rights in Port Arthur.... 
Accordingly, it should be possible for this Government, either singly or in conjunction with Great Britain, to influence the Soviet Government toward a modification in favor of China (and of other countries) of the terms relating to Dairen and the railways, it is believed that we should make the effort. There would seem warrented for such an approach to the Soviet Government on the ground that it was not our understanding of the Yalta Agreement that "internationalization" of Dairen meant transfer of predominent administrative rights to the Soviet Union or that joint operation of the rallways called for transfer of exclusive ownership to the Soviet Union and for vesting Russia with a predominant position in management. If through such an approach the Soviet Union could be influenced to make substantial modification in these proposals it would be very welcome from out point of view. At the same time the facts cannot be lost sight of that National Government of China stands to gain much by Russian participation in the war against Japan and by Russian agreement not to support the Chinese objections to such otherwise reasonable concessions as are not inimical to American interest or in contradiction of American policy....

In respect to any arrangements which may be made between the Soviet Union and the Chinese Government regarding Manchuria we should obtain explicit comnitments from both governments that the principle of nondiscrimination in international intercourse will be respected in all areas and operations which may be the subject of agreement.....

With regard to the proposed arxangenents for Port Arthur it is believed that the Chinese could afford and would be well advised to grant to the Russians privilsges at least no less liberal than those granted to us by Great Britain in connection with the lease of certain naval and air bases in British territory.

There is no reference in the Potsdam Conference papers that Presi-

dent Truman discussed this matter with Stalin in as much detail as the State Department memo suggested. Secretary of State Byrnes, in his book Spending Frankly, did mention the fact that when Truman and Stalin discussed Soviet entry into the war against Japan, on July 17, that

The Generalissimo said he had not yet succeeded in reaching an agreement with the Chinese - a prerequisite to the Soviet declaration of war. He told the President that his negotiations with Premier T. V. Soong would be resumed again after the Conference. 
Among the questions still unsettled was a regime for the port of Dairen. President Truman declared that the United states wanted to make sure Dairen was maintained as an open port. Stalin replied that, if the Soviet Union obtained control of the port, it would have that status. I pointed out that under the agreement, President Roosevelt had entered into at Yalta China was to retain control of Dairen. 40

From July 9 to July 13, Harriman had daily talks with Soong, who reported to him all the details of his negotiations with stalin and Molotov. On July 12, Truman recefved a message from Chiang, via Hurley, expressing his gratitude for the interest shown by Truman and promising to keep $\mathrm{h}$ im constantly informed of the progress of the negotiations. Included in this message was a request for aid and advice:

As this is a matter of grave concern not only between China and Russia but also the interesto of peace and security of the world at large, I earnestly request you to continue to bestow your great attention on it and enlighten me with your views from time to time. 41

On July 19, Chiang sent another message to Truman, after discussing with Soong the Moscow negotiations. 42

Throughout the Sino-Soviet negotiations Ambassador Harriman had been urging the United States Government and State Department to act in a more positive manner to help the Chinese. On July 20, a memorandum was prepared for Secretary Byrnes by the State Department, on Harriman's advice. This memorandum made the following recomendations:

If Russia does not bring the Chinese negotiations up, we should do so and emphasize our firm position. So far as possible, we should avoid any development in China such as have occured in Poland. Accordingly, we should, in advance of any entrance by Russia into the Japanese war, make clear what our position is and shall be with reference to the territorial integrity of China and the maintenance of our traditional "open-door" policy there, without special privileges to any nation.... We should live up to our comitments at Yalta. But we should stand firm and counsel China to stand $f$ irm against any concessions which go beyond the Yalta Commitments. 43

Continuing his policy of urging the United States to support China against excessive demands, and to beware of Soviet intentions, Harriman, 
on July 28, urged the Secretary of State to obtain in writing Soviet reaffirmation of the verbal assurance of stalin to support our "open door" pollcy, and specifically in its application in Manchuria. 44 on July 31 , he again made a request to the Secretary of State. He stated that unless the Chinese gave in, or unless the United States took a firm position on the interpretation of the Ya1ta Agreement the negotiations would break down and the Chinese-Soviet relations would be severely strained. As he knew it would be contrary to the interests of the United States for Soong to go beyond his previous proposals, he reccommended that he be instructed to inform Stalin at the time an impasse seemed to have been reached:

1. that at Yalta, President Roosevelt declined to agree to Stalin's original proposal for a soviet lease of the port of Dalren and Insisted upon its internationalism as a comercial. free port;

2. that we cannot agree to the inclusion of the port in the Soviet military zone or its use as a Soviet naval base; and

3. that if stalin does not agree to Soong's proposals for a free port under Chinese administration with a commercial lease of a certain section of the port for Soviet transit traffic, we propose the creation of an international commission consisting of representatives of the Chinese, Soviet, United States, and possibly British ${ }_{45}$ governments to supervise the operation of Dairen as a free port. 45

Harriman expressed the opinion that the differences regarding the operation of the railroads was not as fundamental as were the port issues, and he thought Soong and Stalin would work those out. He also reaffirmed his opinion that Stalin would give written assurance of the open door policy in Manchuria. 46

With the Potsdam Declaration issued and agreement between American and Soviet military staffs completed, the United States began to feel that it was now important, more than ever now, to have the Sino-Soviet 
negotiations completed. In conversation with Forrestal, Secretary of the Navy,

Byrnes sald he was most anxious to get the Japanese affair over with before the Russians got in, [ with] particular reference to Dairen and Port Arthur. Once in there, he felt, it would not be easy to get them out.... 4

On the 28th, Byrnes sent a message to Hurley stating this, and concluding that it was important that Soong should communicate with Stalin, asking a chance to resume talks. Harriman had now returned to his post In Moscow, and was keeping the President informed of the negotiations. As a result of these reports, President Truman instructed Secretary Byrnes, on August 5, to send new directions to Ambassador Harriman:

I [Truman] asked that Harriman tell Stalin that we believe Soong had already met the Yalta requirements, and we would request that no agreement be made involving further concessions by China.... that might adversely affect our interests "particularly with reference to the inclusion of the Port of Dairen in the Soviet military zone, without consultation with us. 48

Truman did not feel too hopeful about the renewed talks between Soong and Stalin, at this time. ${ }^{49}$ Ambassador Hurley, in Chungking, reported to Truman that Stal in had added new demands. Harriman also reported the new demands expressed by stalin. 50

Harriman concluded his message with a request for further instruction as to the United States' position on the question of war reparations, one of the new demands raised by Stalin,

particularly if Stalin should raise this matter with me. This is another case where Stalin has increased his appetite and I recomend that we resist his demands for shares of stock of Japanese enterprises and restrict the definition of war booty to material that has been historically so regarded in accordance with the United State' definition submitted at potsdam. As to reparations, I recormend that our position should be that all Japanese property, whether in Manchuria or elsewhere, should be available to all countries who have suffered damage by Japanese aggreasion to be allocated by agreement between the powers. As this subject has now been raised, I am fearful that unless we make our position plain at this time, the Soviets will contend that 
that they have the right to define unflaterally war trophies within the areas occupied by the Red Army. I have consulted Ambassador pauley, and he concurs in these recommendations. 51

Harriman continued his protests to Stalin, speaking vigorously against Soviet claims. He denied that the term "preeminent" was intended to support Soviet demands, 52 and continuously reminded him that the president expected to be consulted before any final decisions were made that might affect American interests and policies. Stalin was not too pleased with Harriman's protest, or the Chinese position. Harriman reported, immedlately after the Soviet declaration of war, "that Stalin complained that the Chinese regarded the Soviet Union as an unwelcome guest and that he was angry at their refusal to accept his terms." Harriman believed that Stalin expected Soviet forces to be regarded as liberators. 53

With the Soviet declaration of wax, it became apparent that Soong was weakening seriously in his negotiations with Stalin, as the Chinese were desirous of concluding the agreements before the Soviet forces advanced too far into Manchuria. With this being the situation, Harriman, acting on instruction, informed soong, as a matter of record, that the United States Goverment considered that the proposals which he had already made fulfilled the Yalta Agreement, and that any further concession would be with the understanding that they were made by the Chinese Government because of the value it attached to obtaining Soviet support in other directions. Harriman reported that Soong, "thoroughly understood and accepted the correctness of this position." Harriman further reported that Soong had stated that he was,

very grateful for our support and is convinced that unless we had taken an active part in the nggotiations he would have had to concede to all Stalin's demands. 54 
Throughout the Sino-Soviet negotiations, the United States, by continuous injection of its opinion, kept trying to insure that any accord that was signed would conform to its views of what was concefved at Yalta, and continuously requested written reaffirmation by Soviets of the Open Door Policy in Manchuria. Though there can be little doubt that Stalin's compromises were partially due to American watch over the negotiations, the final treaty and agreements that were signed between the Chinese Goverment and the Soviet Union did not conform entirely with the stated American position, and no signed statement by the Soviets on the Open Door was ever forthcoming.

The Soviet Union and International Law

At Potsdam, Stalin wanted to secure his position regarding international law. From a purely legalistic point of view, the Soviet war on Japan would constitute a breach of the neutralist pact, which had been renounced in April, but was still operative for another year. Molotov suggested, on July 29, that the United States, Great Britain, and other Allies address a formal request to the Soviet Government to enter the war. It was suggested by the Soviets that they

consider that the best method would be for the United States, England and other allies in the Far Eastern war to address a formal request to the Soviet Government for its entry into the war. He said that this would be based on the refusal of the Japanese to accept the recent ultimatum to surrender and made on the basis of shortening the war and saving of lives.

Molotov added immediately that this would be so "assuming that the agreement with the Chinese would be slgned before the Soviet Union entered the war." 55

If the pact was to be broken, Stalin would prefer to have the 
support of the other powers for this violation of international

law.

President Truman was later to say,

The proposal came as a surprise to me. I told Molotov that I would have to give the Soviet suggestion careful examination.... I did not like this proposal for one important reason. I saw in it a cynical diplomatic move to make Russia's entry at this time appear to be the decisive factor to bring about victory. ${ }^{56}$

Truman's fears proved to be true as Soviet historians would later claim that their intervention was the decisive factor in bringing the Japanese war to an end, but Truman decided to prepare a rep1y, against the advice of Admiral Leahy, who said,

I told him I did not believe he should place us under a permanent obligation which would be attached to such a request, and I did not think he should even consider complying. 57

Truman's reply was based upon using the declaration signed at Moscow, October 30,1943 , and the proposed Charter of the United Nations to comply with Stal in's request:

Paragraph 5 of the Declaration signed at Moscow October 30, 1943 by the United States, the Soviet Union, the United Kingdom and China, provides :

15. That for the purpose of maintaining international peace and security pending the reestablishment of 1 aw and order and the inauguration of a system of general security, they will consult with one another and as occasion requires with other members of the United Nations with a view to joint action on behalf of the comminity of nations."

Article 106 of the proposed Charter of the United Nations provides :

"Pending the coming into force of such special agreements referred to in Article 43 as in the opinion of the Security Council enable it to begin the exercise of its responsibilities under Article 42, the parties to Four-Nation Declaration signed at Moscow, October 30, 1943, and France, shall, in accordance with the provisions of paragraph 5 of that Declaration, consult with one another and as occasion requires with other members of the United Nations with a view to such joint action on behalf of the Organization as may be necessary for the purpose of maintaining international peace and security." 
Article 103 of the Charter provides:

"In the event of a conflict between the obligations of the Members of the United Nations under the present Charter and their obligations under any other international agreement, their obligatlons under the present Charter shall prevail."

Though the Charter has not been formally ratified, at San Francisco it was agreed to by the Representatives of the Union of Soviet Socialist Republics and the Soviet government will be one of the permanent members of the Security Council.

It seers to me that under the terms of the Moscow Declaration and the provisions of the Charter, above referred to, it would be proper for the Soviet Union to indicate its willingness to consult and cooperate with other great powers now at war with Japan with a view to joint action on behalf of the community of nations to maintain peace and security.

Sent with this reply to Stalin's request, on July 31, was another note, from Truman to Stalin, stating:

In response to your suggestion that I write you a letter as to the Far Eastern situation, I am attaching a form letter which I propose to send you at your convenience after you notify me you have reached an agreement with the Government of China. If this is satisfactory to you, you can let me know immediately when you have reached such agreement, and I will wire you a letter, to be used as you see fit. I will also send you, by fastest courier the officlal letter signed by me. If you decide to use it, it will be all right. However, if you decide to issue a statement basing your action on other grounds or prefer for any other reasons not to use this letter it will be satisfactory to me. I leave tt to your good judgment. 58

This note, and the form letter that was attached to it, accomplished two purposes, though Stalin expressed his great appreciation of the messages. In the first place, the form letter was not actually a formal request to the Soviet Government for its entry into the war against Japan. It mere1y pointed out the Soviet Union's duty under the Moscow and United Nations agreements in preserving world peace. In the second place, the note attached to this form letter clearly expressed Truman's position in regard to Soviet entry into the war before they had concluded their negotiations with China. The note made it quite clear that there would 
be no official, signed, form letter until then. However, following the Hiroshima bombing, and realizing the situation, the Soviet Unton, knowIng that time was short and that they must act immediately if they were to declare war on Japan before her surrender, did not bother going through the process necessary to enact Truman's form letter. Nor did they wait to conclude the Chinese negotiations, as they had so many times insisted would be necessary, before officlally declaring war against the Japanese. 


\section{CHAPTER V}

THE MONTHS BETWEEN :

February 11 to August 14, 1945

The End of the War in Europe

The combined Anglo-American armies began their crossing of the Rhine on March 24, 1945. Montgomery's British forces in the north, and Bradley's American forces in the center, had converged by April 1 to encircle the Ruhr, and trap more than 300,000 German troopso 1 General Montgomery wanted to drive straight to Berlin. But General Eisenhower, supreme Allied Commander, for what seemed to be sound military reasons, decided to push his main force from the Kassel-Frankfurt area to the Elbe, split the German forces, cut off Berlin from the so called "National Redoubt" area (The Bavarian Mountains, where Hitler was reputed to be preparing for a last stand), and then turn his forces directly to the north and to the southwest of the Elbe. These maneuvers would enable him to seize ports on the North Sea and the Baltic, and also clean up the area to the south before the enemy could assemble a force there. Furthermore, he was to state that "Berlin itself is no longer a particularly important objective," 2

Elsenhower relayed his dectsion to Stalin directly in March 28, under arrangements made in January, and approved by the Combined Chiefs of Staff. Stalin was pleased, but Church 111 was greatly disturbed。 3

Churchill wrote directly to Elsenhower, asking, 
.....why should we not cross the E1be and advance as far eastward as possible? This has an important political bearing, as the Rus$s$ ian armies of the south seem certain to enter vienna and overrun Austria. If we deliberately leave Berlin to them, even if it should be in our grasp, the double event may strengthen their conviction that they have done everything.... I do not consider myself that Ber1 in has yet lost its military and certainly not its political significance. 4

Eisenhower, however, argued that his plan was sound on military grounds; and he had the firm support of other American field generals. "I could see no political advantage accruing from the capture of Berlin that would offset the need for quick destruction of the German Army on our front," General Bradley later wrote. 5

When the American army reached the Elbe, only fifty-three miles from Berlin, the Russians were on the banks of the Oder, thirty to forty miles from the German capital. Churchill continued to argue, urging Roosevelt to act, ${ }^{6}$ but Roosevelt, who had not long to live, was in no condition to argue strenuously with anyone.

Soviet Marshal Georg1 $\mathrm{K}$. Zhukov began a massive offensive across the Oder on April 15, that reached the suburbs of Berlin a week later. American and Russian troops met on the Elbe near Torgau on April 27. Italian Partisans captured and shot Mussolini on the following day. Hitler, realizing the situation, appointed Admiral Karl Doenitz his successor on April 29, and committed suicide on the next day. 7

By March 23, Germany had lost more than a third of the forces which had been guarding the western frontier six weeks earlier. ${ }^{8}$ By May 2, nearly one million German troops in northern Italy and Austria surrendered. Two days later, German troops in northwest Germany, Holland, SchleswigHolstein, and Denmark laid down their arms. Then Colonel General Afred 
Alfred Jikl surrendered unconditionally the remants of the German Army, alr force, and navy at Elsenhower's headquarters at Rheims on May 7 . All hostilities ceased at midnight, May $8,1945 .^{9}$

The War in the Pacific

From any rational point of view, Japan was already defeated by early 1945. It was known that the American conquest of the Philippines would spell the doom of the Empire because it would cut communication between Japan and Indo-China, Malaya, and the East Indies. When the Japanese navy was virtually destroyed at the Battle of Leyete Gulf, it became a matter of time and resources how fast the Allies could move, and when they would begin the actual assault of the Japanese home is1ands. "The day of final reckoning for a treacherous enemy was now at hand," reported General Marshal1. 10

Air attacks continued to greatly reduce the productive capacity of Japan, as it had become almost impossible for them to receive any raw materials by sea. While MacArthur continued in his liberation of the Philippines, American forces were capturing Iwo Jima, 750 miles from Japan, and on April 1; the invasion of Okinawa began.

This large island in the Ryukus group was only 350 miles south of Japan, and both American and Japanese leaders knew that the fall of Okinawa would spell the early doom of the Japanese Empire. A stragegic base within the shadow of the Japanese homeland would be established, the first along the main Japanese Archipelago bordering the East China Sea. Realizing their fate, the Japanese fought frantically, and the battle of Okinawa did not end unt1l June 21 . Only 7,871 out of 117,500 Japanese troops who defended the island survived to surrender. 11 
By this time the main question was whether Japan would collapse Internally before the Americans had launched their final invasion of the island empire. American aircraft from Iwo Jima and Okinawa began to rain a shower of death and destruction on the Japanese home islands unlike anything seen before. American battleships and heavy cruisers joined the attack in mid-July, by shelling industrial targets on the mainland, and by heavy attacks upon Japanese shipping. By early August, little was left standing in the three urban areas that supported Japan's war effort - Tokyo-Kawasaki-Yokohama, Nogoya, and Osaka-Kobe. Most of the essential industrial plants in the smaller towns had been damaged or destroyed. Transit of men and goods in and out of Japan, and even between the ports of Japan, had diminished to almost nothing. American alrcraft launched from land bases and naval carriers, were able to fly unopposed over any part of Japan. 12

Japanese peace feelers had been sent out as early as September and December of 1944, when Chiang Kai-shek had been approached regarding surrender possibilities. General Wedemeyer reported, at the Far East Hearings in 1951, that in the winter of 1944-45 that he, "personally saw overtures proffered by the Japanese for surrender submitted to the Chinese government." He stated that, "the Generalissimo showed them to me," and that he, "saw two on two different occasions, and the terms of the surrender were very favorable to the Chinese Nationalist Government...." 13 But these early maneuvers toward Chungking, "had not only ended in failure but also resulted in severe repercussions within Japan itse1f."14

It should also be noted that as early as September, 1944, in discussions in the Japanese Government, Foreign Minister Shigemitsu was 
suggesting that the Japanese Government should be prepared, upon Soviet Insistence, to recognize a sphere of interest for the Soviet Union in Manchurla and Inner-Mongolia; to give the Kremlin title to Southern. Sakhalin; the northern Kuriles, and the North Manchurian Railway; to acquiesce in the peaceful activities of the Soviet Union in China, Inner-Mongolia, Manchuria, and other parts of Greater East Asia; and to accept an abrogation of Japanese fishing rights in Soviet Far Eastern waters; and to make whatever other sacrifices were necessary to insure success. These measures were being discussed should a deterioration occur in Soviet-Japanese relations, and should Japan wish to guard against a Soviet attack. ${ }^{15}$ The Japanese were obvious $1 y$ aware of the situation and what their position would be shortly and, while not willing to surrender, were prepared to bargain if necessary, and from an inferior position, to maintain what they could of the gains they had made since the early 1930 's.

\section{Japanese Attempts to Negotiate Peace}

Stalin, on May 28, 1945, told Harry Hopkins, during Hopkins? mission to Moscow, that he thought that Japan was doomed, and that the Japanese knew it. Since peace feelers were being put out by certain elements in Japan, he believed the time had cone to "consider together our foint attitude and act in concert about the surrender of Japan." 16 lle feared that Japan would try to divide the Allies, and he did not want that.

Attempted Japanese negotiations, with the Soviet Union in the early part of 1945 , were undertaken only tentatively and no concrete offers were made by the Japanese. The Japanese idea at this time was 
to use Russian mediation in order to forestall a Soviet attack, since the Manchurian army had been considerably weakened by the transfer of a part of it for the defense of the Japanese home 1slands. 17 Dean Acheson, Under-Secretary of State in 1945, testified to this effect at the Far East Hearings in 1951, stating that,

Japanese peace overtures of February 1945 were maneuvers by the Japanese to bring the Russians in as mediators, which was regarded as a mere move on their part to end the war in possession of all the gains wich they illegally acquired before hand and wasn' $t$ regarded as any serious effort at peace, but a mare maneuver. 18

However, on April 5, the Soviet Government informed the Japanese Government that the Neutrality Pact between them "hes lost its meaning, and the continuance of this pact has become impossible."19 By this pact's terms, which were agreed upon and signed in April, 1941, the agreements were to remain in effect for a year after such notice. But there were obvious signs-i.e., movement of troops from the European theater of operations to the Far East-that the Soviet Union did not intend to observe this stipulation. Almost from the moment of the German surrender, Russian troops, now freed for other conquests, began moving to the Far East in impressive numbers.

The possibility of the Soviet Union entering the Pacific war now became a sharp reality to the Japanese, and it was questionable whether or not the Soviets would observe the terms to the letter of the agreement. Molotov, in response to an inquiry from Japanese Ambassador Sato In late April, 1945, affirmed that in spite of the Soviet Union's announcement of April 5, his government would continue to abide by the provision of the Neutrality Pact, and would enjoy neutral relations for the durations of the Pact's validity. 20 
The Japanese had considered Sweden and Switzerland as possibly being used to arrange a conditional peace, before turning to the Soviet Union, but had discarded the idea when there was some question as to whether either of the countries would have made a serious effort, and in addition they did not have the influence with the Allies that the Soviet Union had. 21

In turning to the Soviet Union as their most loglcal and hopeful peace negotiator, it was thought in Japan that the Soviet Union's participation In the Anglo-American alliance was more a matter of necessity, consumated only after Germany chose to invade the Soviet Union, than an arrangement by choice. Japan was thinking that the Soviet Union might prefer to act on her own, belleving that, since the war in Europe had ended, the Soviet Union would not fight if she could gain a dominant position in the Far East merely by acting as Japan's diplomatic broker, not knowing that the Soviet Union had already made other arrangements at Yalta. 22

In mid-May, 1945, former Japanese Premier and one-time Ambassador to Moscow, Koko Hirota, was ordered to undertake to approach the Soviet ambassador to Japan, Jacob A. Malik, to attempt to improve the very poor and unstable relations then existing between Japan and Russia, and to convince the Soviet Union to renew the Soviet-Japanese Neutrality Pact beyond its explration date in April, 1946. The Suzuki Cabinet in the Japanese Government had been formed on April 7, 1945, with the specific mandate to terminate the war, 23 and this was to be their first serious attempt to fulfill their mandate. The meetings took place on June $3-4$, but, as no concrete proposals were offered the Soviets, these attempted preliminary negotiations did not come to any conclusion. 24 
On June 24, Hirota called on Malik again In an attempt to press on negotiations which had been left pending since early June, Hirota very frankly declared that Japan wanted to negotiate a strong agreement to take the place of the Neutrality Pact which had been recently denounced by the Soviet Union. Malik was unimpressed and made statements to the effect and its terms were being honored. 25

HIrota made further tentative offers, but Malik did not respond at a11, and implied that further discussions were useless until Japan would present some concrete plans.

Five days later, on June 29, Hirota made one final vain attempt to solicit the interest of the Soviet Union. This time he submitted concrete proposals in writing; Japan would grant Manchuria her independence, would relinquish Japanese fishing concessions in Soviet Far Eastern waters (in return for oll from the Soviet Union), and would be willing to consider any other matters the Soviet Government might wish to place on the agenda; if the Soviet Union would enter into a nonagression treaty with Japan. 26 These offers were considerably more liberal than were those discussed in September of 1944 , but then the situation in Japan was not the same as it was at that time. Malik promised that these proposals would be reported to Moscow, and that further negotiations would be resumed as soon as an answer had arrived. This ended the negotiations as Malik refused to see Hirota again, and negotiations ceased along this line.

It had now become clear to the Japanese Foreign Office that new and more drastic steps would have to be taken, or else Japan's effort to obtain Soviet good offices would certainly fail. On July 11, the Japanese Minister of Foreign Affairs, Togo, telegraphed the Japanese Ambassador 
in the Soviet Union, Sato, that the situation now demanded more drastic action:

The foreign and donestic situation for the Empire is very serious, and even the termination of the war is now being considered privately.

Conversations are not being limited solely to the objective of closer relations between Japan and the Soviet Union, but we are also sounding out the extent to which we might employ the U.S.S.R. in the connection with the termination of the war....

Therefore, although we of course wish the completion of an agreement from the Malik-Hirota negotiations, on the other hand, sounding out the Soviets as to the manner in which they might be used to terminate the war is also desired. We would like to learn quickly the intentions of the Soviet Government regarding the above. 27

Sato was to see Molotov in regard to the above, and find out what he could.

July 12, Togo sent a following message that Sato was to convey to the Soviet Government before the Soviet leaders left for the conference in Berlin:

His Majesty the Emperor is greatly concerned over the daily increasing calamities and sacrifices forced by the citizens of the various belligerent countries in the present war, and it is His Majesty's heart's desire to see the swift termination of the war. In the Great East Asia War, however, as long as America and England insist on unconditional surrender, our country has no alternative but to see it through in an all-out effort for the sake of the survival and the nonor of the homeland.....he intends to dispatch Prinçe Fuminaro Konoye as a special envoy to the Soviet Union..... 28

Sato was to obtain Soviet permission for the entry of the envoy, and to arrange transportation for Konoye to Moscow. Molotov was too busy to see Sato, but Sato was able to arrange an interview with Vice-Foreign Comissar Lozovsky instead, at which time he presented his proposals. Sato did not receive a reply to his ṕroposals, and sent a message on July 15, to Togo, stating that Stalin and Molotov had left for the conference 
without giving a definite answer. Sato also took this opportunity to explain once again to Togo his belief that nothing less than a concrete proposal would receive any attention from the Soviet Union and that the mission, "should be nothing other than a proposal for peace and termination of hostilities." 29

Sato did not receive a reply from the Soviet Government until

July 18, at which time he telegraphed the Soviet answer to Toto:

[ reply of the Soviet to envoy]

By the order of the Government of the U.S.S.R., I have the honor to call your attention to the fact that the Imperial views stated in the message of the Emperor of Japan are general in form and contain no concrete proposal. The mission of Prince Konoye, special envoy, is also not clear to the Governent of the U.S.S.R.

The Government of the U.S.S.R., accordingly, is unable to give any definite reply either as to the message of the Emperor of Japan or to the dispatch of Pringe Konoye as special envoy mentioned in your note of July 13.30

On July 21, Togo dispatched another cable to Sato in which he endeavored to define the Konoye mission in terms which could leave no doubt in Soviet minds as to Japan's intent and purpose. In a second telegram, sent the same day, Togo further spelled out for Sato's benefit the position of the government in Tokyo: Japan could not accept "unconditional surrender under any circumstances." That as long as such a demand remalned, the Japanese people would fight on as one man. At the same time, in accordance with the wishes of the Emperor, Japan hoped through the good offices of the Soviet Union to bring about peace on terms other than unconditional surrender. It was highly important, according to Togo, that Sato make every effort to insure that the United States and Great Britain understand this point. 31

Togo further explained that because of the situation both at home and abroad that Japan could not set forth actual peace terms, but that 
France Konoye would be sent to present the concrete intentions of the Japanese Government. Togo was not above using other means in an attempt to achieve his purposes. He told sato to make a personal appeal to Stalin's vanity, to use this as a bargaining point in the negotiations, Thts telegram included the following otutement:

...request the good offices of the Soviet Union and that the sending of the envoy to the Soviet Union would enable Stalin to acquire the position of advocate of world peace. Also make it clear that we are fully prepared to recognize the wishes of. the Soviet Union in the Far East. 32

This telegram did not arrive, for unknown reasons, in Moscow until July 24, at which time Sato again managed to see Lozovsky. This time his instructions enabled him to specifically state that Japan was seeking the good offices of the Soviet Union in order to bring the war to an end, and it was for this purpose Japan desired to send Prince Konoye. The Soviet Union sent a letter to Sato stating that the character of the last proposal was so general, contained no specific proposal, and therefore it was Impossible to give a definite reply. 33

Stalin reported these overtures to President Harry Truman at the Potsdam Conference. At the first meeting of Truman and Stalin on July 18, Stalin told of the Japanese proposals and gave Truman a copy of the Emperor's message of July 12. Stalin had then inquired if Truman thought the message worthwhile answering, to which Truman answered in the negative. ${ }^{34}$ Truman mentioned peace feelers from the Japanese through Sweden at this time, but did not make any other reference to them. 35

It is certain that the United States knew of the Japanese overtures to the Russians, prior to the conference. By early July, Washington had intercepted messages from Japan to the Japanese ambassador in Moscow. 
Secretary of the Navy, Forrestal, recorded in his diary on July 13 , that,

The first real evidence of a Japanese desire to get out of the war came today through intercepted messages from Togo, Foreign Minister, to Sato, Jap Ambassador in Moscow....36

Further entries in Forrestal's diary indicate that messages were also Intercepted on July 15 and July 24. (However, the historians who compiled the Potsdam Conference papers could find no evidence that the United States representatives knew of the Japanese overtures to the Soviet Union made after the opening of the conference.)

On July 28 , Stalin said he wished to make an announcement before the business of the regular meeting started. Stalin then had read the latest message they had received from Japan. After the interpretor finished reading the Japanese message to Russia, Stal in declared

that there is nothing new in it except that it was more definite than the previous approach and that itwould receive a more definite answer than was the $\xi_{7}$ case last time. The answer would be in the negative, he said. 37

On July 30, Sato again called upon Vice-Foreign Comissar Lozovsky In the hope, this time, of obtaining a clear statement of Moscow's intentions. Lozovsky was noncomittal, promising only to inform Molotov that the ambassador had come seeking a reply. Ambassador Sato waited each day in Moscow for a reply. On August 5, upon hearing that Molotov had returned from Berlin, Sato formally requested an interview with him. Two days later, on August 7, he was notified that Molotov would be able to see him the next day, August 8. At the appointed hour Sato arrived at the Kremlin. He was imnediately informed that Molotov had a notification to the Japanese Government. After waiting a week sato recelved an answer from the Soviet Union, he was handed the Soviet declaration of war : 
After the defeat and capitulation of Hitlerite Germany, Japan remained the only great power which still stands for the continuation of the war.

The demand of the three powers, the United States, Great Britain, and China, of July 26 for the unconditional surrender of the Japaneese armed forces was rejected by Japan. Thus the proposal made by the Japanese Government to the Soviet Union for mediation in the Far East has lost all foundation.

Taking into account the refusal of Japan to capitulate, the Allies approached the Soviet Government with a proposal to join the war against Japanese aggression and thus shorten the duration of the war, reduce the number of casualties and contribute toward the most speedy restoration of peace.

True to its obligation as an Ally, the Soviet Goverment has accepted the proposal of the Allies and has jointed the declaration of the Allied powers of July 26.

The Soviet Government considers that this policy is the only means able to bring peace nearer, to free the people from further sacrifice and suffering and to give the Japanese people the opportunity of avoiding the danger of destruction suffered by Germany after her refusal to accept unconditional surrender.

In view of the above, the Soviet Government declares that from tomorrow, that is from August 9, the Soviet Union will consider herself in a state of war against Japan. 38

The End of the War in the Pacific

Word came to the American leaders, on July 16, that an atomic bomb had been exploded in New Mexico, when Secretary of War Stimson brought President Truman the news. ${ }^{39}$ Knowing that the bomb was finally a reality, and Its use might avert the necessity of a long and bloody campaign in Japan, Truman now concentrated on a public warning to Japan. This public warning, known as the Potsdan Declaration, was issued on July 26, under Truman's, Churchill's, and Chiang's signatures. Stalin did not sign as the Soviet Union was not yet at war with Japan. Paragraph thirteen of this declaration stated:

We call upon the government of Japan to proclaim now the unconditional surrender of all Japanese armed forces.... 


\section{tion. 40 The alternative for Japan is prompt and utter destruc-}

This declaration was published and broadcast to the world, but strangely enough no evidence has been found in the Department of state files to indicate that the test of the Potsdam Conference Declaration was transmitted to the Japanese Government through neutral diplomatic channels.

The leaders of the Suzuki Government in Tokyo agreed to accept the Potsdam Declaration, but with qualifications; main1y concerning the position of the Emperor, and the position of the Japanese military. It was the military in Japan that so strongly opposed unconditional surrender, preferring to fight to the very end rather than be forced to give up their position in Japan.

On July 28 , United States radio monitors reported that Radio Tokyo had reaffirmed the Japanese Government's determination to fight. The Potsdam Declaration had been referred to as "unworthy of consideration," "absurd," and "presumptuous,"41 A press conference statement by Prime Minister Suzuki immediately after the Potsdam Declaration was broadcast, contained the following statement:

I belleve the Joint Proclamation by the three countries is nothing but a rehash of the Cairo Declaration. As for the Government, it does not find any important value in it, and there is no other recourse but to ignore it completely and resolutely fight for the successful conclusion of the war. 42

President Truman and his advisers took this as a refusal and decided to use the new weapon, the atomic bomb. President Truman was later to say that this decision was based on the following reasons:

On July 28 Tokyo announced that the Japanese government would continue to fight. There was no formal reply to the joint ultimatum of the United States, the United Kingdom and China. There 
was no alternative now. The bomb was scheduled to be dropped after August 3 unless Japan surrendered before that day. 43

An Invasion would undoubtedly have been successful but at a great cost in human 11 ves to both sides. Truman did not hesitate - "I regarded the bomb as a military weapon and never had any doubt that it should be used"44 - and on August 6, a lone B-29 bomber flew over Hiroshima and dropped the first atomic bomb.

President Truman received word - "Big Bomb dropped on Hiroshima August 5 at $7: 15 \mathrm{p} . \mathrm{m}$. Washington time. First reports indicate complete success which was even more conspicuous than earlier test ${ }^{145}$ - aboard ship on the journey home from Berlin the same day from Secretary of War Stimson. He promptly anncunced the news to the world, stating "we are now prepared to obliterate more rapidly and completely every productive enterprise the Japanese have above ground in any city," and warned the Japanese that, "If they do not now accept our terms, they may expect a rain of ruin from the air, the like of which has never been seen on this earth. "46

Still the Japanese army refused to surrender. The civil government and the military in Japan were clearly in disagreement and had been for some time. It was really a question of who had the power and the upperhand. This was a rather unique situation, summed up quite well by Toshikazu Kase, in his book Journey to the Missouri:

In order to safeguard her precarious independence under constant foreign pressure, it was an urgent necessity for Japan to create a modern national defense force with the utmost speed. Military affairs therefore took precedence over other business of government, a fact which tended inevitably to strengthen the position of the military. Moreover, the Supreme Military Command enjoyed extraordinary prerogative's under the Constitution, making it entirely independent of the civil government. These prerogatives were considered unimpeachable and unquestionable. By exploiting them the fighting services consolidated an unassailable position which was no less than that of a state within a state. 47 
Then, on August 8, the Soviet Union issued their declaration of war on Japan. Molotov sent for Ambassador Harriman the same day, and announced to him that the Soviet Union would consider itself at war with Japan as of August 9. The following day Harriman reported to Washington further on the Russian decision:

When Molotov informed the British Ambassador and me last evening that the Soviet Union would consider itself in a state of war with Japan as of August 9, he emphasized that although at one time it was thought that this action would not take place until mid-August the Soviet Government had now strictly 1 ived up to its promise to enter the Pacific War three months after the defeat of Germany. 48

Plans had been gone over carefully at Potsdam for Russian participation in the war. American leaders still welcomed Russian intervention even though they were by no means as eager for it as they had been earlier. Russian troops quickly began to advance into Manchuria, meeting only slight opposition from the Japanese troops there.

August 9, the United States dropped a second atonic bomb on Nagasaki, and, when hurried conferences falled to yleld agreement to accept the Potsdam ultimatum, the Emperor of Japan made the decision for peace. The Japanese Government informed the Washington Government on the followIng day that it accepted the Potsdam terms, provided that the status of the Emperor would not be changed. The military and naval leaders of Japan balked when Washington replied on August 11, that the Emperor must be subject to the Supreme Commander of the Allied Powers. But the Emperor insisted, and the Japanese Government formally accepted the Allied demands on August 14, 1945. 49 
CHAPTER VI

CaNcLusion

W1th the final signing of the Sino-Soviet Treaty of Friendship and Allance, and the exchange of notes corapleted between the signatories, on August 14, 1945, the Yalta Agreement concerning the Far East was completed. A closer look at the final agreements is now in order. A comparison and evaluation of the Yalta Agreement and the Sino-Soviet treaty and agreements is perhaps the best manner in which to accomplish this.

The Yalta Far East Agreements and the Sino-Soviet Agreements

The opening statement of the Yalta Agreement pledged the Soviet Union to enter the war against Japan. Marshal Stalin told Harry Hopkins, May 26, that the Soviet amies would be in position to engage the Japanese in China and Manchuria by August 8,1 and though the Soviets maintained that they would not be ready unt 11 late August, and not then unless the final Chinese negotiations were finalized, they were ready on time. The Soviet declaration of war was presented to the Japanese on August 8 , to be effective August 9. As this 1ived up to their exact pledge of the Yalta Agreement, the Soviets were quick to point this out to the Americans. Regardless of what else may be satd of their later actions, the Soviets honored this military commitment, as they had consistently honored military comitments thoughout the war. 
The Soviet military men at Potsdam had maintained that they would not be in position to move until late August, and they had continuously stressed the need to finalize the Chinese negotiations in order "to justify entry into the Pacific War in the eyes of the Soviet people."2 The obvious speculation at the "premature" entry of the Soviets into the war is that they wanted to make sure they would be in position, if the surrender should occur immediately after the dropping of the atomic bomb, to make good the claims that they had been negotiating for with the Chinese. Clearly they would have difficulty justifying any claims they had if they did not make any contribution to the war effort in the Pacific. This obvious baste did not enable them to use the letter they had requested of President Truman, though their declaration of war would state otherwise.

It was believed that the Japanese could not have held out much longer, and would soon surrender, and that the Soviet Union need not have expended their forces to invade Manchuria. And of course, the Soviet Union did officially enter the war five days before the final negotiations with the Chinese were corapleted.

There has always remained the question that perhaps stalin and the Russians could have moved sooner into Manchuria than they did, making the atomic bomb unnecessary, and ending the war sooner. Admiral King offered the following speculation at the Far East Hearings in 1951:

My expectation was that the Soviets would enter the conflict in the Far East sooner than they did, but perhaps Stalin and company were getting back at the Allies for not opening up the second front in Europe sooner than they did. 3

There was also some concern on the part of the Americans that the Soviet Union "would wait until the war was over, and until we had expended 
our effort and blood to win the war," and then come in and do as they wished. 4 The question was being asked "whether they would come in early enough to be of any help to us and to save American 1ivas." 5 Though it must be said again that the Soviets, in honoring vital military commitments prior to that time, had "built up favorable opinion among the peoples of the United States and the other western allies." 6

The second part of the Yalta Agreement that concerned a Soviet pledge was its readiness, and willingness, to conclude with Nationalist China, a pact of friendship and alliance. This pledge was fulfilled with the final signing of the treaty and agreements of August 14.

Though the Soviet promise of aid and assistance was somewhat late, as the war did not last long enough for them to provide much military assistance or support, it was technically in time as the Soviet declaration of war did cone before the Japanese surrender.

Article III of the August 14th agreement concluded an alliance against Japan. With the conclusion of this portion of the agreement the Soviet Union had seemingly given Nationalist China what they had long desired. The two countries had pledged mutual respect for their sovereignty and territorial integrity, and of non-interference in the internal affairs of the other. The Soviet Union further recognized the National Chinese Government as the central government of China, and her full sovereignty over the Three Eastern Provinces.

As of August 14, the Soviets had unquestionably fulfilled its pledges made at the Yalta Conference. In fact, looking at the SinoSovlet agreements so far, there can be little doubt that the Soviet Union made solid commitments and promises. Commitments and promises long desired by the Chinese. The Chinese were so pleased with these 
portions of the Sino-Soviet agreements, that the subsequent concessions they were to make were made because of this desire and the long felt need for such agreements.

The last portion of the Yalta Agreement requiring the Soviet Union to act, was the provision that the ports and railway agreements needed the concurrence of Generalissimo Chiang Kai-shek before being completed. This concurrence was gained in the notes exchanged following the Treaty of Friendship and Alliance. It is these subsequent notes and agreements which will not be examined.

The first of the Soviet conditions was that the status quo in Outer-Mongolia should be maintained. This point, as was mentioned earlier, caused much discussion, debate, and disagreement early in the negotiations as the Chinese were determined not to cede any of China's territory away, and the Soviet Union, as a result of the Insertion ("The Mongolian People's Republic") in the Yalta Agreement, claimed this provision meant independence. However, Chiang authorized this concession early in the negotiations, and it ceased to be a point of contention.

The exact position taken by the United States Government concerning Outer-Mongolia is somewhat confusing. In a State Department memorandum prepared at Harriman's request, the recommendation was made that it would be wise for the Chinese Government to give formal recognition to a situation which had long existed. However, earlier, on July 4, Truman had instructed Byrnes to inform Harriman that he could "informally" confirm to Soong that his understanding was that in so far as the United States was concerned there was no discussion of interpretation of the wording of the Yalta decision, that status quo was just 


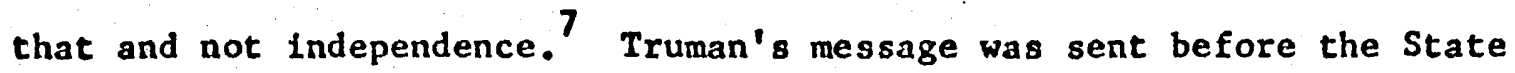
Department made its recommendation, and the issue was settled before then anyway, but there was definitely contradiction within the ranks of the American leaders. However, as the United States had officially refused to act as interpreter, Soong and Chiang did what they had to in the reality of the situation. Reallzing they were making a concession, but also realizing the situation, and at the same time wanting to save face, they agreed that the question of independence would be settled by a plebiscite of the people.

This undoubtedly went beyond the Yalta understanding, as only the status quo was agreed upon in the original agreement. The wording though should have been clarified at the time the agreement was made. In all reality though, China had not exerted any measure of control over this area for many years, and with the situation being what it was, she could hardly have expected to then. Had the Chinese not made this agreement it seems unquestionable that the Soviets would have aided any attempt by the people of Outer-Mongolia to free themselves of any semblance of Chinese rule had they chosen to make an issue of it.

The Soviets were also willing to state, with respect to the province of Sinkiang, that they had no intention of "interfering in the Internal affairs of China." That this provision was mentioned specifically is cause for some speculation. Undoubtedly the Chinese wanted this included as protection from any designs the Soviet Unton might have in this area. This must have been the topic of some discussion as it must have been a very real possibility to the Chinese that they could lose the entire northern portion of their country if they did not safeguard against such actions. 
The two items of the Yalta Agreement concerning the southern part of Sakhalin and the Kurile Islands were the most easily disposed of in the Sino-Soviet negotiations. The Chinese did not need to be consulted, and their concurrence was not part of the original agreement. Traditionally and historically, the Chinese did not have any interests in these areas, and a Harriman memorandun to Secretary Byrnes July 18, 1945, stated that, "China raises no objection and accepted the return to Russia of the southern part of Sakhalin and the accession of the Kurile Islands," 8 so apparently this was at least mentioned in passing during the Sino-Soviet negotiations, and was never a point of contention. Chiang had attempted to bring these areas under the control of a four power commission, but had given up the idea when the United States had not shown an interest.

The remainder of the Yalta Agreement, concerning the ports and the railroads, proved to be the focal point of the majority of the SinoSoviet disputes during their negotiation.

Difficulties over the interpretation of the Yalta Agreement arose from the very beginning, with the Soviet Union interpreting the agreement to suit its own purposes.9

When Molotov first presented Harriman with the Soviet drafts of the proposed Yalta Agreement, it contained no mention of the "preeminent interests of the Soviet Union being safeguarded," and it was not until further discussion had clarified other points in dispute, and the final draft written out by the Soviet Union, that this phrase appeared. This phrase, to which President Roosevelt apparently made no protest, proved to be the point upon which the Soviet Union based their arguments in the negotiations with the Chinese. 
It is not known if any discussion took place concerning this phrase at Yalta. Harriman, who was directly involved in the discussion at Yalta, and was in close contact with Soong all during the Sino-Soviet negotiations, was to express the following opinion in his statement to the Senate Comnttee at the Far East Hearings in 1951:

I can personally state that neither Roosevelt nor Stalin intended that the phrase 'preeminent interests' should go beyond Soviet interests in the free transit of exports to and imports from the Soviet Union. President Roosevelt had told me at Yalta that this was his interpretation and when I took this position with Stalin in August, 1945, he agreed.10

But there was to be considerable difference in what Stalin said, and in what he did.

Rooseve1t, Churchi11, and Stalin had discussed at the Tehran Conference the possibility that the Soviet Union be given the "use of a warm-water port at the end of the Manchurian railway, possibly at Dairen, on the Kwantung Peninsula," knowing that this was a long-time Soviet wish. ${ }^{11}$ With this as a basis for discussion, the Yalta Agreement included the provision that Dairen be internationalized.

The final agreement concerning Dairen signed by the Chinese followed this closely. In point one they agreed that Dairen would be a free port open to the commerce and shipping of all nations; point three agreed that the administration in Dairen would belong to China; point five provided satisfactory customs agreements; and point two of the Protocol to the Agreement stated that all of the railways would not be subject to any military supervision or control other than by the Chinese. These arrangements were all highly satisfactory to the Chinese.

However, the remainder of the Dairen agreement highly favored the Soviet Union, and, as subsequent events proved, gave the Soviet Union virtual control of this port. The "preeninent interests" of the Soviet 
Union were protected to the sum of one half of all the port installations and equipment, on lease, free of charge.

That the restoration of Manchuria to the National Government would take place through this, the only major port available to the Chinese into Manchuria, would undoubtedly work an undue hardship on the Chinese. But then, Stalin had wanted all of Dairen on lease, and had also wanted to include a naval base there, and the Chinese had at least half of the facilities at their disposal, which was more than they had had for the past fifty years, and all of the port would not be under Soviet domination, as they had feared, and would have been the case had no agreement been made.

A portion of the agreement that would cause much trouble as was quickly seen, was the provision that in case of war against Japan the port was to be subject to the military supervision or control of the Soviets as determined by the Agreement on Port Arthur. Soong had managed to resist Stalin's demands as long as possible, but ultimately did give in to the provision that Dairen be included within the Soviet military zone, but he had hoped that he had protected Chinese interests with the provision about no Soviet control except in war time.

On this last point it is interesting to note that Dairen was not opened to the commerclal vessels of the world in the months following the surrender of Japan, and upon protests by the United States, the Soviet Union replied, referring to the provision of the agreement regarding Dairen, that in case of war with Japan, Dairen was to come under the control of the military regime authorized for the Port Arthur Naval Base area. They continued in their replies to state that "in as much as the war with Japan had not been terminated, there being no peace 
treaty, Dafren came under the administration of Port Arthur." The Soviet Union also stated that it saw no basis for a change of the regime, and the port remained closed to commercial intercourse with other countries。 12

The Yalta Agreement provided for the lease of Port Arthur as a naval base of the Soviet Union be restored. Stalin had argued for this lease, and President Roosevelt had given in when Stalin showed willingness to compromise on the port of Dairen and the railroad. In a11 reality it would have been difficult to argue against a great power like the Soviet Union not being in control of a port in this area. Especially in light of the threat Japan had just posed to the Pacific countries. With the conclusion of the Sino-Soviet negotiations, the Soviets not only had a lease of the Port Arthur area, but also had managed to create a military zone that extended north on the Kwantung Peningula, but excluding Dairen and the connecting railways. It was agreed that the naval base would be for the joint use of the two countries, to be used only by Chinese and Soviet military and commercial vesse1s.

This was to be the sole Chinese benefit under this arrangement, and it was clear that the port would be in foint use on paper only. There could be little doubt that whatever use the Chinese would make of the port, would be that which the Soviets allowed them, there would be no equality. But then, this agreement was clearly intended by the signatories to predicate Soviet domination. And, though the agreements they had made were much more conciliatory, the United States had concluded similar agreements with other countries for bases.

The lease of Port Arthur was the one portion of the Sino-Soviet agreements that wasld seem to be unquestionable. That the Soviet Union did not have an ice-free port on the Pacific was a long felt need and 
desire of the Soviet Unton. For their needs in this area an internationalized port would not entirely serve their needs. Had the lease been for only Port Arthur, no one would have either questioned it or disputed 1t. However, in view of the fact that the United States saw this arrangement similar to privileges which they had negotiated with other countries for the mutual security of two friendly nations, the Soviet appetite in this area was far too large, and they subsequently far overstepped what they could legitimately have expected as their due.

The last portion of the Yalta Agreement that required concessions by the Chinese was the provision concerning the Chinese Changchun Railway. The Yalta Agreement had provided that the Chire se Eastern and the South Manchurian railways, providing an outlet to Dairen, should be jointly operated by the establishment of a joint Soviet-Chinese Company.

The remainder of this agreement should also have been satisfactory to the Chinese, as long as the Yalta Agreement had been made, and the need felt for the concluding of the Sino-Soviet agreements. The Chinese Government would bear the responsibility for the protection of the railway, and only during the time of war against Japan would the Soviets have the right to transport troops.

These agreements, on paper, would seem to avoid any infringement on Chinese sovereignty; they would not have complete control of the railroad, but they had never had that, nor had they even built the major portion of it. They were certainly in a much more favorable position than when the railroad was originally built. Logically the agreenent was sound. Due to the geographic location of the Soviet maritime provinces, this arrangement was highly desirable to that country. The railway had been under foint ownership, though under Soviet domination, 
since its construction, until the time Japan assumed control of the area through the puppet state of Manchukuo. A successful working agreement would have done much to solidify the working relationship between the two countries, and greatly lessen tensions.

Taking into consideration repeated affirmations by the Soviets, and there were many, to guarantee Chinese sovereignty in these areas, the fact that the Nationalist Chinese Government did not have the area directly under their control, and had not for some time, the fact that the area was being 1 iberated by the Soviet armies, and the fact that orfginally Stalin had wanted to lease the rallroads in their entirety, and later demanded complete ownership, and most important, had it in his power to assume full control had there not been any concluding agreement, the compromises worked out seemed highly favorable to the Nationalist Chinese.

To a large extent the Chinese anxieties, and the compromises they made, were based on the knowledge that the Soviets would soon be launchIng an invasion of Manchuria from Siberia and Outer-Mongolia. This knowledge definitely influenced the Chinese negotiations up to August 8 , and even more so after the Soviets launched their invasion. It placed the Chinese in a position where the agreement regarding relations between the Chinese administration and the Commander-in-Chief of the Soviet forces in the Three Eastern Provinces was almost as desirable as the Treaty of Friendship and Alliance. Knowing that the Chinese Communists were in a position to move into this area easily and readily after the conclusion of the Japanese war, and knowing that they could be there far In advance of the Nationalist forces, and in all probability would receive ald from the Soviet forces, this was extremely desirable to 
Chiang. And the Soviets gave them the assurances they wanted.

This agreement gave the Soviet Commander-in-Chief full authority In all matters related to the prosecution of the war, and was to be expected. If the Soviets had their forces there, and did not assume control, chaos and trouble would surely follow. There was no objection from the Chinese as the Soviets had stated that as soon as any area ceased to be a zone of Immedlate milltary operation the Chinese National Government would assume full control in the direction of public affairs. Once again this seemed to affirm the desire of the Soviet Union to cooperate with the Nationalist Chinese as the government of the country.

In suming up the final agreements made, in comparison with the Yalta Agreement, there was cause for Chinese displeasure only on the port of Dairen. The agreements, as clearly written, seemed to give the Chinese what they had long desired; security in that they could act without fear of Soviet interference, as they had been assured in the Treaty of Friendship and Alliance that the Soviets would not interfere in the internal affairs of China, and assurances from the Soviets that they would recognize Chinese sovereignty and territorial integrity, and of vital importance, considering the many years of dispute and fear of the Chinese Communists, was the pledge by the Soviets that all aid and support would be given entirely to the National Government as the central government of China.

Unquestionably China benefitted because she gave up little to the Soviet Union that the Soviet Union had not had at one time, or could not have taken at any times she desired, and in all probability held. And China had not controlled any of the areas in the agreements for several 
years. There was good and sufficlent cause for Chlang to be satisfied and happy with the completion of the agreements.

Reaction to the Sino-Soviet Agreements

On August 16, 1945, Chiang informed Ambassador Hurley that agreement had been reached with the Soviet Union and that he was generally satisfied with the treaty. He admitted that he thought the Sino-Soviet treaty indicated; (1) an intention on the part of the Soviets to assist in bringing about unification of the armed forces in China; (2) an intention to support Chinese efforts to create a strong, unified and democratic government; and (3) an intention to support the Nationalist Government of China. 13 In his report to the State Department, Hurley was to say,

The publication of these documents has demonstrated conclusively that the Soviet Union supports the National Government and also that the two governments are in agreement regarding Manchuria. 14

Secretary of State Byrnes, In officially expressing the opinion of the State Department, stated that:

I believe that the new treaty between the Nationalist Government of the Republic of China and the Government of the U.S.S.R. and the accompanying agreements constitute an important step forward In the relations between China and the Soviet Union.....ve welcone this development as a practical example of the continuing unity and mutual helpfulness which should characterize the acts $g^{f}$ members of the United Nations in peace as well as in war.

Editorial comment in both Nationalist and Chinese Communist territory newspapers expressed approval of the Sino-Soviet treaty and related agreements at the time they were made public. Harriman confirmed this in his statement at the Far East Hearings, "When the Sino-Soviet agreements were made public in August they were welcomed both in China and in the United States."16 Harriman further stated that, "Soong told 
me In Moscow he was gratified at the results obtained." 17 Acheson confirmed both Harriman's and Hurley's statements in his testimony at the Far East Hearings. He stated:

At the time the Chinese entered into this treaty with the Russians they regarded the arrangements which they had made with the Russians on the basis of Yalta, as very satisfactory..... such statements were expressed by the Generalissimo Chiang Kai-shek, and the Chinese Foretgn Minister. 18

\section{Yalta Comitments and American Policy}

There is little doubt that the Yalta Agreement committed the United States, and subsequently China, to a series of provisions seemingly inconsistent with policy established from the very beginning of the war. There can also be little doubt that these commitments were thought to be vitally necessary to the war effort. Seemingly they also may have been inconsistent with the Atlantic Charter, in light of later developments, but they did not disagree with this Charter as it was written. These agreements did not actually violate Chinese sovereignty, if anything, they protected it to a greater extent than ever previously. Had the American Chinese policy been successful, unquestionably the final agreements would have been beneficial both for China and the Soviet Union. Beneficial to China because it would solidify the relationship between the two countries, and ease the tension that had existed for some time between them. It would have naturally been beneficial to the Soviet Union because it would have solved problems which had been confronting them ever since their arrival on the shores of the Pacific; their lack of warm-water ports on the Pacific, and the easing of transportation problems to the Marltime Provinces, as the long trip around the Chinese border would no longer be necessary. 
The United States had long desired a strong, unified China, that she might "become the principal stabilizing factor in the Far East."19 A strong, unified China could have, and would have, protected her interests against any and all aggressors, and would have been the police force necessary to retain stability in that area. There could be little doubt that China had tremendous potential. Though China would be some time in fulfilling its role as a great power, the United States had worked for her acceptance with the other powers for some time. And she would have had sufficient power, had United States policy been successful, to take care of herself at the end of the war:

There can be little question, again in view of the situation, that the Yalta Agreement, made by Stalin and Roosevelt, would be beneficial to both, as interpreted by Roosevelt and the United States.

Even though China was forced to concede more than the Yalta Agreement provided for, she gained enough in exchange to counterbalance the concessions she had made. She was sufficiently protected, had she been able to fend for herself as a strong, unified country. It is clear that China's failure to consolidate within herself, and not the Yalta Agreement as insinuated by some, led to her ultimate downfall. The Yalta Agreement did not create the Communist Chinese. Anthony Kubek, in his book, How the Far East was Lost, states, "There is little doubt that Yalta marked the greatest diplomatic defeat in American history." 20 Kubek bases his belief, to a minor extent, on quoted sources that he believes conclusively upholds this belief, and, in the majority, from hindsight so beneficial to those who are quick to criticize, and are not able to see the situation in perspective as is necessary in a11 fairness to those concerned. 
Kubek quoted Hurley from the Far Bast Hearings to the effect that Hurley belleved,

American diplomates surrendered the territorial integrity and the political independence of China, surrendered the principles of the Atlantic Charter, and wrote the blueprint for the Communist conquest of China in secret agreement at Yalta....21

yet does not include turley's statement of August 16,22 ar which time he did not belleve the same thing. Clearly Hurley also benefited greatly from hindsight in his criticism. If he was 80 positive in his assertions six years later it would seem that he would have been able to see the situation more clearly in 1945.

The mistake the United States made was not at Yalta, but in China. The idealistic wish and desire of American policy was the fundamental weakness. The consistent and constant expression by the UnIted States to China that she must make her own decisions, and stand on her own two feet, was simply not possible in light of the existing conditions in China. That "our policy toward China is not based on sentiment," that it was "based on an enlightened national self-interest motivated by considerations of international security and well-being," 23 as expressed by the State Department at the time of Yalta, was simply not true It was based on idealism, sentiment, and considerable hope, in light of traditional American policy. That the United States was never prepared to go to war over China to protect either its rights or aid the Nationalist Chinese Government in their internal struggle with the Chinese Communists, was what created the problems with China, not the Yalta Agreement. American leaders knew that the vacuum created by the defeat of Japan would have to be filled in order that some semblance of balance would be restored in the Far East, and they knew if it could 
have been filled by the Chinese, it would free the United States from assuming any responsibility in that area after the war. This was the overriding hope and concern of the United States in the formulation of Chinese policy.

During the Sino-Soviet negotiations the Chinese had asked for help from the United States, had asked them to exert their strength of opinion with the Soviets, and aid in the negotiations, as the Chinese clearly wished to know officially what the United States' interpretation of the Yalta Agreement was in order that it could be used in their negotiations. All that was ever expressed officially by the United States was that they did not think it necessary for the Chinese to go beyond the limits set at Yalta. This was not much help as even today it is not entirely clear what was intended by the wording of the Agreement. The United States had had its:opportunity to intervene decisively and did not do so.

The responsibility they can assume for the final Sino-Soviet treaty is that they did not take a strong stand, did not express their opinion clearly. In light of the position they took, it would seem that it would be hard for anyone to criticize the Chinese for any concessions they may have made to obtain what they ultimately desired, and received from the Soviets, at least on paper, the assurances of friendship and sovereignty.

Harriman ultimately summed up the reallstic view of the Yalta Agreement when he stated that,

The postwar problems have resulted not from the understandings reached at Yalta, but from the fact that Stalin failed to carry out those understandings and from the aggressive action by the Kremlin. 24 
and,

the loss of control over the mainland by the National Government was due not to the Yalta understanding, but to the façt that the Soviet Union broke the Sino-Soviet agreements. 25

Chiang Kai-shek believed the same thing, stating that:

The Sino-Soviet Treaty of Friendship and Alliance and its various annexes together with Stalin's pledge are useful today as the yardstick with which to measure Soviet Russia's bad faith as demonstrated in her subsequent diplonatic and military action. 26

The Soviet Union and the War Against Japan

At the war's end, it was clear that "the effect of Russia's entry into the Pacific war....neither defeated Japan nor materially hastened the acceptance of surrender..." 27 The Soviet Union was not needed to defeat the Japanese. The Yalta Agreement need not have been made. It is interesting to note though, that Soviet historians would explain the surrender of Japan as being entirely due to the timely intervention of the Soviet Union.

During June, the American position regarding the Soviet Union's entry into the war had changed somewhat as it became increasingly clear that it would only be a matter of time before Japan would fall. No longer was the opinion almost unanfmous that the Soviet armies would be needed to bring about the Japanese capitulations. The position of the American leaders was now fluctuating between trying to figure out a way to keep the Soviet Union out of the war, and having them fulfill their pledge for the psychological shock it might have on the Japanese.

UItimately, neither position was to correspond with subsequent events. It would not have been possible to keep the Soviet Union out of 
the war; nor was the psychological shock to have any apparent effect on the Japanese, as interviews after the conflict proved.

A necessarily candid report was given on September 4, 1945, by

the then Premier Prince Naruhike Higashi-Kuni to the Japanese Diet:

The general conditions of the country began to show marked signs of impoverishment and exhaustion....so much so that in the days just preceeding the termination of the war it seemed almost impossible to carry on modern warfare further for any long period of time.... Our losses in naval and aerial strength werk 80 enormous as to obstruct seriously the prosecution of the war.

The influence of Secretary Byrnes, General Eisenhower, Admirals King and Ieahy, and others, in expressing their opinions to the President, apparently were able to influence him in his decisions. In preparing for the Potsdam Conference, Truman was to state, "my immediate purpose was to get the Russians into the war against Japan as soon as possible."29 But later was to change this position somewhat as he said in early August, "Stalin had said that Russia would not come into the war against Japan unt 11 she had concluded an agreement with China. It was for this reason that I urged Chiang to continue the talks in Moscow. 30 "

Truman wanted to get a Soviet declaration of war at Potsdam in case their help was needed against the Japanese. 31 This position was undoubtedly taken with the knowledge that the atomic bomb would quickly end the war, but there were others who were not certain the bomb would work ${ }^{32}$ and a Soviet declaration of war would be insurance against such $a$ happening.

However, others, like General Marshall, thought that

the Impact of Russian entry on the already helpless Japanese may well be the decisive action levering them into capitulation at that ${ }_{3}$ time or shortly thereafter, especially if we land in Japan. 33 
Originally Soviet intervention in the Pacific war had been desirable of what was then considered military necessity, but was now being considered in the manner in which Marshall indicated. There was also the possibility, until mid-July, that the atomic bomb would not work, and even at the last minute there were doubts that it would explode in the air when dropped over Japan.

It was for that reason that military plans for an invasion of the Japanese home 1slands continued to be worked out, and these plans definitely stated that American military leaders wanted to "encourage Russian entry into the war against Japan," 34 and that it was worthwhile to fulfill the Yalta pledges. ${ }^{35}$ on July 24, 1945, during the conference, Harriman reported that the Combined Chiefs of Staff reported to the President and Prime Minister Churchill, that their overall strategy concept included, "still planning an invasion and still considered Soviet participation in the Pacific war essential." 36 However, the feeling of American leaders, other than the military, was indicated by a note Churchill recorded after talking with Byrnes, on July 24: "It is quite clear that the United States does not at the present time desire Russian participation in the war against Japan."37

It should be noted that the military was not unanimous in their desire to seek the help of the Russians. After a June 18, meeting of the Joint Chiefs, Admiral King was to state quite emphatically that, in spite of the position of the Chiefs of Staff,

Regardless of the desifability of the Russians entering the war, they were not, in his opinion, indispensable, and he did not think that we should go so far as to beg them to come in. While the cost of defeating Japan would be greater without Russian aid, there would be no question.... but that we handle it alone. 38 
U1timately his, and Admiral Leahy's opinions were correct.

Admiral Leahy had firmly belfeved at Yalta that the Russians were not needed, as he had stated that by September of 1944 he

believed that a completely blockaded Japan would fall by its own weight.... [and that] Japan was almost defeated . [ithen] through practically complete sea and air blockade .....39

He advised Truman of the same thing prior to and during the Potsdam Conference. He told Truman that, "The British and ourselves were fully capable of defeating Japan without assistance." 40

The United States State Department had been in agreement with the military at Yalta. They regarded the

Sino-Soviet cooperation as necessary for peace and security In the Far East and seek to aid in removing the existing mistrust between China and the Soviet Union and in bringing about close and friendly relations between them. 41

If American policy were to succeed without armed intervention then this cooperation between the Soviet Union and China was necessary. And it was thought to have been accomplished with the Yalta Agreement, as well as gaining the military support of the Soviet Union in the Pacific war.

It seemed clear at Yalta that the Soviets had no ulterior motives. Stalin repeated to the conference what he had told Roosevelt privately: "[D] only want to have returned to Russia what the Japanese have taken from my country. $" 42$ Roosevelt agreed to this and Leahy was to say later that,

It seemed very reasonable to me. also, and no one was more surprised than I to see these conditions agreed to at Yalta labeled as some horrendous concession made by President Roosevelt to an enemy. 43

Stalin desired no more than historical precedent would allow, at that time, he desired to return to the position occupled by the Tsarists at one time, and Acheson observed at the Far East Hearings, that, 
the Russians took the same attitude toward these rights that the Chinese took toward their rights in Formosa. The Russians had lost theirs to the Japanese by war In 1904; the Chinese had lost theirs to the Japanese by war in 1895.44

Stalin had given "unqualified endorsement" to the Cairo

Declaration, though he sald he could make no commitment because of the neutrality pact with Japan. 45 Th1s declaration pledged that the powers involved would "covet no gain for themselves and have no thought of territorial expansion." There would seem to be some question of Stalin's intentions, except this declaration could also be interpreted to support the position of the Soviet Union as it was also stated in this document that, "Japan will also be expelled from all other territories which she has taken by violence and greed." There was no clarification of this last statement, no determination as to what would happen to those fomer Japanese possessions, and it definitely would seem to Indicate a return to others what they had also lost, and the Soviet Union certainly regarded certain of these rights as having been lost to the Japanese in 1904, as the statement in the Yalta Agreement indicated: "The former rights of Russia violated by the treacherous attack of Japan in 1904 shall be restored...."

\section{Summary}

One fact can be stated with certainty about the Yalta Agreement and that is that the range of feelings and criticisms are as extreme as they could possible be.

The Far East Hearings of 1951 brought forth virtually reams of criticism, to the extent that the final resume stated that: 
The turning point of American forelgn policy in the Far East was the Yalta Agreement of February 1945.... The surrender of the principles and objectives by the State Department at Yalta created the confusion, the crisis which confronts our Nation today. 46

During the testimony the following statements were made by two of the biggest critics of the Agreement. General MacArthur referred to Yalta as a great tragedy, stating that, "one of the greatest mistakes that was ever made was to. permit the Soviet Union to come down into China at Port Arthur, Dairen and other places of that sort." 47 General Hurley stated that,

Our diplomatics surrendered the territorial integrity and the political independence of China in a secret agreement at Yalta. We surrendered in that secret agreement the objectives for which we had told the American people we were fighting. 48

and, "I believe that the verdict of history on the Yalta Agreement w111 mark it as both immoral and cowardly."149

Hurley was not as outspoken in his criticisms in 1945, and General MacArthur was another who had taken quite a different position at that time. On February 28, 1945, MacArthur expressed his opinion to Secretary Forrestal, to the effect that,

he felt that we should secure the commitment of the Russians to active and vigorous prosecution of a campaign against the Japanese in Manchukuo of such proportions as to pin down a very large part of the Japanese army....50

Clearly he too, had been able to benefit from hindsight.

Admirals King and Leahy did not testify at the Far East Hearings, but statements by both were introduced as evidence. Both had long opposed Russian participation in the war on military grounds, but neither offered the criticism afterwards that others did. And these two were among the few who remained consistent in their views. 
The final conclusions of the Senate Comnittee were made in light of firm statements that the Yalta Agreement did not materlally affect the situation which arose on the Asiatic continent after World War II. Secretary of State, in 1951, Acheson testified that the agreements, "ware in the intereste, the long-term interests of China,"51 and in answer to a question of military connection between the defeat of China and those concessions made to the Soviet Union at Yalta, he replied, "I just don't believe there is any connection at all."52 Admiral Barr, Chief of the Army Advisory Commission in Nanking from January, 1948, to May, 1949, testified that he did "not think the Yalta Agreement had any considerable effect on the final fall of Chiang,"53 and, "it was no doubt a contributing factor but was not a major cause, China would have fallen even if the Yalta Agreement was not made." 54 Ambassador Harriman stated that,

the loss of control over the mainland by the National Government was due not to the Yalta understanding, but to the fact that the Soviet Union broke the Sino-Soviet agreements. 55

It is doubly hard to understand the position taken by the Senate Comittee after reading the above testimony and the observations made by the following people. They both would seen to clearly repudiate the criticisms offered by MacArthur, Hurley, and others.

Admiral Leahy stated that,

On his way back to Moscow from the San Francisco Conference, Ambassador Harriman discussed with me his latest estimate of. Soviet intentions regarding Japan. Harriman believed that Russia would cone into the war, regardless of what we might do, and that, in the end Moscow would exercise control over whatever government might be established in Manchuria and Outer-Mongolia. I had held the same opinion ever since the conditions for Russian participation in the Far East conflict had been accepted. 56 
General Marshall had pointed out to Secretary of War, Stimson,

That even if we went ahead in the war without the Russians, and compelled the Japanese to surrender to our terms, that would not prevent the Russians from marching into Manchuria anyhow and striking, thus permitting them to gain virtually what they wanted in the surrender terms. 57

General Deane stated in his book, The Strange Alliance; that,

I do not think that any responsible American ever doubted that Russia would eventually come into the war against Japan. The Soviet Union had too many interests in the Far East to have allowed the affairs of that part of the world to be settled without her participating voice, and she could hardly have claimed a place at the peace table without having been one of the victorious belligerents. 58

From the above evidence it seems clear that the Soviet Union would have entered the war, regardless of what was done at Yalta. Stalin had intended to enter the war long before the Yalta Agreement was made. Stalin's desires in the Far East did not suddenly materialize from thin air at Yalta. If what he originally asked Roosevelt to verify as Soviet rights to be restored were any indication of what Soviet desires in the Far East were, then certainly the Yalta Agreement could well be viewed as imposing, along with the Sino-Soviet treaty and agreements, "legal limitations on the action which Russia would, in any case, have been in a position to take." 59 And,

only by maintaining strong military forces In Japan could we have forced Russia to live up to its claims and to withdraw from the territory which it controlled. 60

Another factor, apparently completely ignored by Hurley, MacArthur, and others, was the American people. Senator Alexander Wiley, of Wisconsin, in a speech before the Senate in July of 1945, clearly indicated the feelings of the American people at that time: 
It does not involve any military secrets to state our intense feelings in this matter. In millions of American homes, mothers; fathers, and sweethearts, are waiting anxiously for news of Russia's intentions.... They know and we know that if Russia declared war, if her bombing fleets roared out of Vladivostok over Japan, these acts might be the final ones to force a quick surrender of the Japs. Thus, countless American lives are at stake in Russia's decision.... We know that whether or not Russia enters the war she will make big postwar demands regarding Asia at the pade table. Thus America has everyching to gain and thousands of her boys' lives to lose unless Russia joins in the Pacific struggle. 61

Secretary of State Stettinius stated that at the time of Yalta, "it must be remembered that there was already a groundswell of public opinion demanding that our forces be returned home as soon as the war was over."62 The American people were in no mood to fight any more after the surrender of Japan, certainly not the Soviet Union. Ambassador Harriman stated this clearly:

The people of the United States were in no mood to support such an undertaking. This country certainly errored in its rapid demobilization in 1945, but this is an error for which the entire American people must share the responsibility. 63

It is not possible to see into the future.

In view of world developments since the conclusion of hostilities against Japan, especially in recent years, there is no evidence to suggest that the absence of such arrangements, 1.e. Yalta Agreements and Sino-Soviet Treaty and agreements would have restrained the Soviet Union from pursuing Russia's longrange traditional objectives. 64

How would it have been possible to realistically ask a country to come into a conflict in which they need not have become involved except by choice (it was clear that the Japanese would not have been in a position to threaten them), to save the lives of American soldiers, and not be willing to give in to what seemed to be, in 1945, just, desirable, and necessary claims? This would have been expecting too much from a country which had suffered the blunt of the German attack for three years 
while waiting for an Allied second front, a nation that had suffered untold damage and devastation, a nation that was to fight long and hard on her own soil, a nation that suffered over $20,000,000$ casualties in the war. The United States entered the war only after being attacked! This is the perspective in which the situation must be viewed. Had China been strongly united, there would never have been any question raised. Certainly had the Americans not been so desirous of saving lives, while at the same time asking the Soviets to become involved in a situation where they would lose yet even more of her boys' lives, perhaps the situation would be different in China today.

This certainly does not indicate that subsequent Soviet actions since that time should be excused. But, up to 1945, the American people had assumed a rather self-centered attitude toward the war, and it is not unreasonable to think that other countries also felt the same way. The Yalta Agreement does not appear out of perspective when viewed in terms of the situation in 1945. The Sino-Soviet Agreement of August 14, 1945, clearly vindicated American policy up to that time.

In 1945, in China, the Nationalist Government of Generalissimo Chlang Kai-shek remained in power. There was good reason to assume that with the pledged support of the Soviet Unton and of the United States, it would gradually overcome the opposition of the Chinese Communists, and consolidate its authority over a united nation.

It was thought, during the war, that American influence should be used to obtain an agreement between China and the Soviet Union which would preclude Soviet interference in China's Internal affairs or encroachment upon Chinese territory. This was done, and while a few 'were questioning the wisdom of some of the Far Eastern Agreements made 
at Yalta,

those who were not motivated by purely political partisanship were generally willing to concede that, if these agreements would tend to prevent postwar controversies between the major allies, make for co-operation between Moscow and Washington, as well as between Moscow and Nanking, and promote the rapid pacification and recovery of a devastated sector of the globe, the concessions by China that they involved would be justified in China's own highest interest. 65

The concessions that China was forced to make were justified by what she received in return from the. Soviet Union. The Soviet Union did enter the war as promised in the Far East Agreements at Yalta, and seemingly the Sino-Soviet Treaty and related agreements assured a good working relationship between the two countries. And the Soviet Union was Iimited in its demands upon and in China, and had promised to both aid and support the Nationalist Government, and to respect its sovereignty.

It was not either of the two agreements, the Yalta Far East Agreement, or the Sino-Soviet agreements, that brought about the downfall of Nationalist China. Neither of these two agreements created the Chinese Communists. It would have been necessary for Chiang to consolidate dissident elements within his own country for these agreements to successfully work out. And he was not able to do this. Attempts were made by the United States during and after the war to bring the two opposing forces together in China, but they were always, unsuccessful. The Yalta Far East Agreement was not a radical shift in American China policy, as believed by the Senate Committee and others. It was not a radical change in traditional American policy. The Yalta Agreement had been consistent with American policy in that it was an attempt to 
both protect China, and help establish her as a world power. And, had China been able to stand on her own feet as a united country after the war, this policy would have been successful, and they would have been able to assume their place as a world power, as President Roosevelt had dreamed.

In January of 1950 , the U.S.S.R. signed a peace treaty and alliance with Communist China, which had forced Chiang and the Nationalists off the mainland in 1949, and had given up all the claims and rights granted by the Nationalist Chinese in 1945; ample proof that the Soviet Union did not desire any trouble with a China that was able to present a united front and stand up for her rights, though the circumstances had changed at that time.

There was very little that the United States could have done to help the Nationalist Government. The basic formulation of policy at the turn of the century prevented any ald in the form of troops, which would have been the only aid that would really have helped Chiang at that time. And it is doubtful even if that would have been enough unless the United States were willing to become involved in another full scale war, which they were not. And clearly, from subsequent events in China, any agreements or policies formulated in 1945, would have had to be supported by both armed forces and the Soviet Union if they were going to be successful. Had the United States been willing to force the 1ssue in 1945 and 1946, undoubtedly the situation would have been different today, but they did not. This was not the fault of President Roosevelt, who did not make this policy, and President Truman, who could not change it. 
As events quickly showed, Chiang never really had the whole-hearted support of the Chinese people during the war. Their contribution to the Allied war effort was clear indication of this. The situation was one which the Nationalist Government had to work out for themselves after the war before any outside involvement would have helped them.

President Roosevelt had been a realist. Without the United Nations functioning as planned, there was little chance of lasting world peace. Without the support and cooperation of the Soviet Union there was little chance of this happening. The United Nations would have soon gone the way of the League of Nations. President Roosevelt attempted to bring this about. Had he lived he might have been successful. However, he did not, and in light of what the people of the United States were willing to support, what more could have been done? 


\section{FOOTNOTES}




\section{FOOTNOTES}

\section{CHAPTER I}

$1_{\text {Sir Edward Hertslet, Treaties, between Great Britain, China and }}$ Foreign Powers (London: Harrison and Sons, 1908).

2Ibid., p. 438 .

3 Ibid., p. 439.

4Ken Shen Weigh, Russo-Chinese Diplomacy 1689-1924 (Bangor: University Prints, 1928), p. 25 .

5Hertslet, I, 439-49.

6ien-fong Cheng, A History of Sino-Russian Relations (Washington D.C.: Public Affairs Press, 1957), P. 29.

TIbid., p. 31 .

8 Ibid., p. 31 .

9 Ibid., p. 36 .

$10_{\text {Ibid., P. } 37 .}$

11 Hertslet, I, 454-55.

12 weigh, p. 37.

13 Hertslet, I, 455-61.

${ }^{14}$ Ibld.; p. 454 .

15cheng, p. 36 .

16 Ibid.

17 Weigh, p. 36 .

18 Cheng, p. 36 .

19 Hertslet, I, 470 .

20 Weigh, pp. $41-42$. 
$21_{\text {Cheng, p. } 37 .}$

22Morinosuki Kajima, A Brief Diplomatic History of Modern Japan (Rutland: Charles E. Tuttle Co. Publishers, 1965), p. 215.

${ }^{23}$ Cheng, p. 51 .

24 Ibid., p. 52.

${ }^{25}$ Ibid.

26 Harold M. Vinacke, A History of the Far East in Modern Times (New York: Appleton-Century-Crofts, Inc., 1950), p. 144.

27John V.A. MacMurray (ed.), Treaties and Agreements with and Concerning China 1894-1919 (New York: Oxford University Press, 1921), I, $81-82$.

${ }^{28}$ Ibid., I, 82.

${ }^{29}$ Andrew Malozemoff, Russian Far Eastern Policy 1881-1904 (Berkeley: University of California Press, 1958), p. 82-83.

30. The intricacies in the modern pattern of Far Eastern history began to appear after the year 1894. It was a war between China and her then small neighbor, Japan, which revealed the complete helplessness of China and encouraged the Powers of Europe to believe that she might shortIy fall to pieces and be partioned among them." Harold M. Vinacke, A History of the Far East in Modern Times, p. 76. The ensuing scramble of the European powers in China brought her to the verge of being dismembered by the end of the nineteenth century.

31 MacMurray, I, 119-120.

32 Ernest Batson Price, The Russo-Japanese Treaties of 1907-1910 Concerning Manchuria and Mongolia (Baltimore: The John Hopkins Press, 1933), p. 164 .

${ }^{33}$ Cheng, p. 66.

${ }^{34}$ Quoted in Malozemoff, p. 149.

${ }^{35}$ Ibid., p. 150

${ }^{36}$ Ibid., p. 158.

37 Ibid., p. 160.

${ }^{38}$ vinacke, pp. 146-47.

${ }^{39}$ Hertslet, I, 510 .

40 Malozemoff, Pp. 205-206. 
41cheng, p. 68 .

42 price, p. 19.

43 Ibid.

44Malozemoff, p. 173.

45Ibid., Pp. 237-49.

46 Ibid.

47.price, p. 23.

48MacMurray, I, 523.

49 Ibid.

50 Ibid., p. 524.

51 Ibid., Pp. 524-25.

52Quoted in Price, p. 107.

53 Ibid., pp. 107-108.

54 Ibid., p. 113.

55 Ibid., Pp. 113-14.

56 price, p. 59.

57 Quoted in Price, p. 117.

58price, p. 77.

59 Ibid., p. 78.

60Ibid., p. 79.

61 Mingchien Joshau Bau, The Foreign Relations of China (New York: Fleming H. Revell Company, 1921), Pp. 257-62.

62 Ibid.

63Price, pp. 121-22.

64C1aude A. Buss, The Par East (New York: The MacMillian Company, 1955), P. 209.

65Ful1 text of the Nine Power Treaty may be found in United States Relations with China (Washington D.D.: Dept. of State Publications, Division of Publication, Office of Public Affairs, 1949), pp. 438-42. 
167

${ }^{66}$ Chang, p. 115

67Vinacke, p. 405

${ }^{68}$ Ibid., pp. 405-406.

${ }^{69}$ Ibid., p. 411

$70_{\text {Buss, Pp. } 217-19}$

$71_{\text {Ibid., p. } 221}$

72 Chang, p. 185

${ }^{73}$ Ibid.

74 Ibid.

${ }^{75}$ Ib ld., pp. 185-86.

76 United States Relations with China, p. 45

${ }^{77}$ Ching Kai-shek, Soviet Russia in China (New York: Farrar,

Straus and Giroux, 1965), p. 56.

78 Ibid. 
CHAPTER II

${ }^{1}$ Chester Wilmot, The Struggle for Europe (New York: Harper \& Brothers Publishers, 1952), p. 621

2 Ibid., p. 622.

${ }^{3}$ Ibid., p. 624 .

${ }^{4}$ Ibid.; p. 632 .

5. F. Fleming, The Cold War and Its Origins (Garden City: Doubleday \& Company, Inc., 1961), I, 97.

6Lesile Roberts, Home From the Cold Wars (Boston: The Beacon Press, 1948), p. 116.

7John R. Deane, The Strange Alliance (New York: The Viking Press, 1946), P. 93.

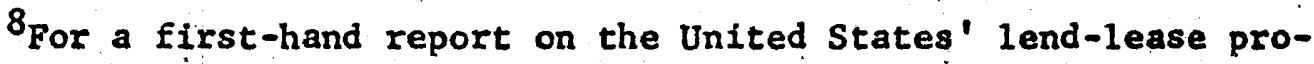
gram to Russia, see Chapter VI in The Strange Alliance.

${ }^{9}$ Dwight D. Eisenhower, Crusade in Europe (Garden City: Garden City Books, 1951), pp. 225-26.

10 Bohlen Minutes, First Plenary Meeting concerning "The Military Situation," as expressed by General George Marshall, U.S. Department of State, Foreign Relations of the United States, The Conferences at Malta and Yalta (Washington D.C.: U.S. Government Printing Office, 1955), p: 575. Cited hereafter as Yalta Conference.

${ }^{11}$ Ibid., p. 578.

${ }^{12}$ Combined Chiefs of Staff Minutes, meeting, February 5, 1945, Ibid., p. 603.

13 Bohlen Minutes, First Plenary Meeting concerning "The Military Situation," as expressed by General George Marshall, Ibid., p. 578.

14 Combined Chiefs of Staff Minutes, meeting, February 4, 1945, Ibid., p. 587.

15 Walter Millis (ed.), The War Reports of George C. Marshall, H. S. Arnold, Ernest J. King (Philadelphia: J.B. Lippincott Company, 1947), p. 201. Citer hereafter as The War Reports. 
${ }^{16}$ Quoted from an unidentified source headed "Russia's Position," that Harry Hopkins had with him at the Quebec Conference, was said to be quoted from a "very high level United States military strategic estimate." Robert E. Sherwood, Roosevelt and Hopkins (New York: Bantam Books, 1950), II, 364.

17 Wilmot, p. 622.

18 Ibla., p. 623.

${ }^{19}$ Combined Chiefs of Staff Minutes, meeting, February 4, 1945, Yalta Conference, p. 581 .

${ }^{20}$ Report by General George Marshall, The War Reports, p. 266.

${ }^{21}$ Ibid., p. 292

22Leslie R. Groves, Now It Can be Told, The Story of the Manhattan Project (New York: Harper \& Row, Publishers, 1962), p. 9.

23 Ibid., p. 11.

24 Edward R. Stettinius, Jr., Roosevelt and the Russians: The Yalta Conference (Garden City: Doubleday \& Company, 1949), p. 90.

25 Henry L. Stimson, "The Decision to use the Atomic Bomb," Harper's Magazine, Vo1. 194, No. 1161 (February, 1947), p. 98.

$26_{\text {F1eming, I, } 204 .}$

27Document, "Declaration on Liberated Europe," The Yalta Conference, $p .977$.

${ }^{28}$ Ibid.

${ }^{29}$ Frederick I. Schuman, Russia Since 1917: Four Decades of Soviet Politics (New York: McGraw-Hill Book Company, Inc., 1957), p. 260.

${ }^{30}$ Louis L. Snyder (ed.), Documents of German History (New Brunswick: Rutgers University Press, 1958), pp. 447-48.

31 U.S. Department of State, "Pact of Neutrality Between the U.S.S.R. and Japan," Bulletin, Vo1. XII, No. 305 (April 29, 1945), P. 812.

32State Department Briefing Book Paper, "Outlines of Short-Range Objectives and Policies of the United States with Respect to China," Yalta Conference, p. 355.

33 Bohlen Minutes, Roosevelt-Stalin meeting, February 8, 1945, Ib1d., p. 771. 
34 Telegram, Ambassador in China, Hurley, to President Roosevelt, January 14, 1945, Ibid., p. 348.

35state Department Briefing Book Paper, "Political and Military Situation in China in the Event the U.S.S.R. Enters the War in the Far East," Ibid., p. 351 .

36 Joseph W. Stilwell, The Stilwell Papers (New York: William Sloane Associates, Inc., 1948), p. 316 .

${ }^{37}$ Henry L. Stimson and McGeorge Bundy, On Active Service in Peace and War (New York: Harper \& Brothers, 1947), p. 528.

${ }^{38}$ Samuel Eliot Morison, The Battle of the Atlantic: September 1939-May 1943 (Boston: Little, Brown and Corapany, 1960), I, P. 46.

${ }^{39}$ stimson, On Active Service in Peace and War, p. 528.

40stilwe11, p. 348 .

41 Ibid., p. 328.

42 Ibid., p. 348 .

43 Ibid., p. 318.

44 Ibid., p. 321 .

45 Ibid., p. 340. Congressman Mike Mansfield, in January of 1945, in his report to Congress following his return from a mission in China, expressed an opinion similar to Stilwell's: "On the basis of information which.I have been able to gather, it appears to me that both the Communists and the Kuomintang are more interested in preserving their respective Parties at this time and have been for the past two years than they are in carrying on the war against Japan. Each Party is more interested in its own status because both feel that America will guarantee victory." U.S. Relations with China, p. 52.

${ }^{46}$ Combined Chiefs of Staff Minutes, meeting with Roosevelt and Churchil1, February 2, 1945. Yalta Conference, P. 544.

${ }^{47}$ Ibid.

48 Belief expressed by General George Marshall, The War Reports, p. 209.

\footnotetext{
${ }^{49}$ Ib fd.. p. 215.

${ }^{50}$ Ibid., p. 216.

51 Ibid.
} 
52 Ibid., p. 222.

53 Ibid., P. 229.

${ }^{54}$ Combined Chiefs of Staff Minutes, report by General Marshall at meeting February 6, 1945, Yalta Conference, p. 654.

55Douglas MacArthur, Reminiscences (New York: McGraw-Hill Book Company, 1964), P. 217.

${ }^{56}$ Ibid., p. 245.

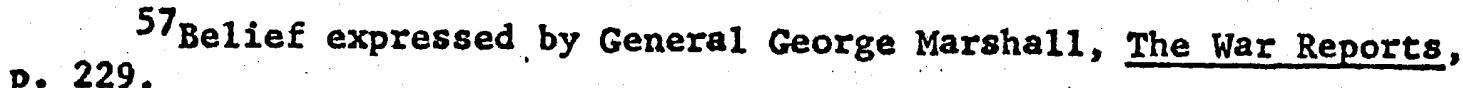

- ${ }^{58}$ Corabined Chiefs of Staff Minutes, meeting February 1, 1945 , Yalta Conference, p. 520 .

59MacArthur, p. 260 .

60 Bohlen Minutes, Roosevelt-Stalin meeting, February 8, 1945, Yalta Conference, p. 766.

61Combined Chiefs of Staff Minutes, reports by General Marshall and Admiral King, February 1, 1945, Ibid., pp. 518-19.

62stimson, On Active Service in Peace and War; pp. 618-19.

63 stettinius; p. 98 . 
1John L. Snell (ed.), The Meaning of Yalta (Baton Rogue: Louislana State Univarsity Pross, 1956), p, 130.

2Frances Valeo, The China white Paper (Washington D.C.: The Libracy of Congress, 1949), P. 5 .

$3_{\text {Alfred Whitney Griswold, The Far Eastern Policy of United }}$ States (New York: Harcourt, Brace and Company, 1948), p. 321.

${ }^{4}$ Signatories of this treaty were the United States, Great. Britain, Japan, France, Italy, the Netherlands, Portugal, Belgium, and China.

${ }^{5}$ Full text of the Nine Power Treaty may be found in United States Relations with China, p. 438-42.

GUnited States Relations with China, p. 11.

7 Ibld., p. 443.

8 Ibid., p. 12.

${ }^{9}$ Ibid., p. 448.

${ }^{10}$ Ibid., p. 37.

11 Herbert Feis, The Road to Pearl Harbor (Princeton: Princeton University Press, 1950), p. 245.

12 The British Empire received $\$ 30,269,210,000$, the Soviet Union $\$ 10,801,131,000$, France $\$ 1,406,600,000$, and China a total of $\$ 631,509,000$ in lend-lease from the United States between March, 1941 and October 1, 1945. Twenty-First Report to Congress on Lend-Lease Operations for the Period Ended September 30, 1945 .

13United States Relations with China, p. 36.

${ }^{14}$ Ibid.

${ }^{15}$ Combined Chiefs of staff Minutes, meeting, February 2, 1945, Yalta Conference, P. 544.

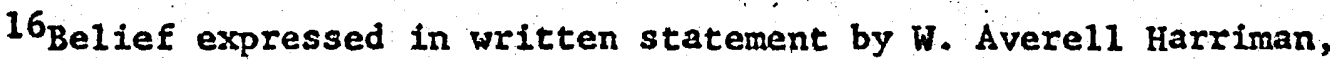
U.S. Congress, Senate Comittee on Armed Services and Foreign Relations, Hearings on the Military Situation in the Far East, 82nd Congress, Cont'd. 
161st Session, 1951, p. 3337. Cited hereafter as Far East Hearings.

17 Bohlen Minutes, Roosevelt-Churchill-Stalin meeting, November 30,1943, U. S. Department of State, Foreign Relations of the United States, The Conference at Cairo and Tehran: 1943 (Washington D.C.: U.S. Government Printing Office, 1961), P. 556. Cited hereafter 28 Cairo and Tehran Conference. 448-49.

18 Full text of Calro Declaration may be found in Ibld, Pp.

19 Winston S. Churchil1, Triumph and Tragedy (New York, Bantam Books, 1962), p. 559.

20 State Department Briefing Book Paper, "Outline of Long-Range Objectives and Policies of the United States with Respect to China." Yalta Conference, p. 356.

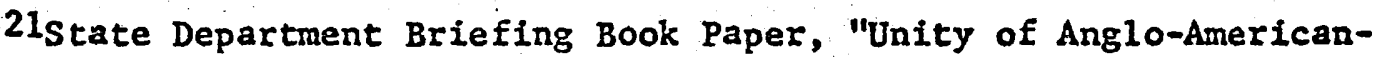
Soviet Policy Toward China," Ibid., p. 353.

22State Department Briefing Book Paper, "Outline of Long-Range objectives and Policies of the United States with Respect to China," Ibid., p. 356

${ }^{23}$ Ibid., p. 357.

${ }^{24}$ Far East Hearings, Pp. 563-64.

25 MacArthur, p. 270.

26 Yalta Conference, p. 395.

27 Report by General George Marshall, The War Reports, pp. 243-44.

$28_{\text {Report }}$ of the Combined Chiefs of Staff to President Roosevelt and Prime Minister Churchill, February 9, 1945, Yalta Conference, p. 830.

${ }^{29}$ Stimson, On Active Service in Peace and War, p. 619.

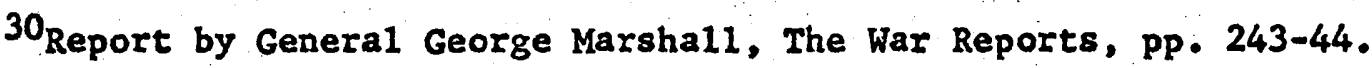

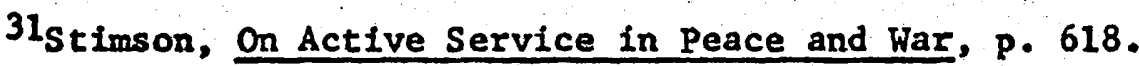

32 Ibid.

${ }^{33}$ Sherwood, II, 364.

34 Ibid., II, 512.

${ }^{35}$ stettinius, p. 96. 
36wa1ter Millis (ed.), The Forrestal Diaries (New York: The Viking Press, 1956), P. 31. Cited hereafter as The Forrestal Diaries.

37 Report by United States Joint Staff Planners, "Russian Participation in the War against Japan," Yalta Conference, p. 392.

38William D. Leahy, I was There (New York: McGraw-Hill Book Company, 1950), p. 259.

39 Ibid., p. 293.

40 Ibid., p. 318.

41 stettinius, p. 98 .

42 Far East Hearings, p. 3329.

${ }^{43}$ Cordell Hull, The Memoirs of Cordell Hull (New York: The Viking Press, 1948), II, 1310.

44Deane, Pp. 241-42.

45 Telegram, Comanding General Deane, United States Military Mission in the Soviet Union ot the Joint Chiefs of Staff, October 17, 1944, Yalta Conference, P. 372.

46 Telegram, Ambassador Harriman to President Rooseve1t, December 15, 1944, Ibid., pp. 378-79.

47 stettinius, p. 92 .

48 Bohlen Minutes, Roosevelt-Stalin meeting, February 8, 1945, Yalta Conference, p. 769 .

49 Ibid., p. 896.

50 Bohlen Minutes, Roosevelt-Stalin meeting, February 8, 1945, Ibid., p. 769 .

$51_{\text {Leahy, p. } 318 .}$

52 Written statement by W. Averel1 Harriman, Far East Hearings, p. 3334.

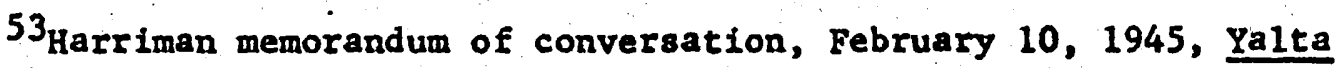
Conference, p. 894.

54 Churchill, p. 334 .

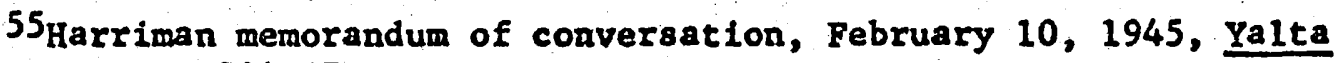
Conference, Pp. 894-97.

56Ibid., p. 895. 
${ }^{57}$ Herbert Feis, The Chins Tangle (Princeton: Princeton University Press, 1953), pp. 250-51.

58 yalta Conference, p. 984.

${ }^{59}$ Churchil1, p. 335 .

60 stettinius, p. 95.

61U. S. Department of Defense, "The Entry of the Soviet Union Into: the war against Japan," p. 40, cited in Snell, The Meaning of Yalta, p. 147. 3332 .

62 Written statement by $w$. Averell Harriman, Far East Hearings, p.

${ }^{63}$ Far East Hearings, p. 1845.

64Kuter Minutes, statement by General Antonov of the Soviet Union, meeting of the American and Soviet Chiefs of Staff, February 9, 1945, Yalta Conference, p. 835.

65Feis, The China Tangle, p. 139.

66 Memorandum prepared by Hugh Borton of the Department of Territorial Studies, January 10, 1945, Yalta Conference, p. 385.

67 Ibid., pp. 387.

68Memorandum prepared by George H. Blakeslee of the Department of Territorial studies, December 28, 1944. Ibid., p. 379.

${ }^{69}$ Ibid., pp. 379-83.

70 Telegram, Ambassador Harriman to President Roosevelt, December 15, 1944, Ibid., p. 379.

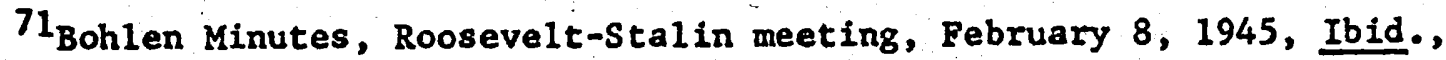
p. 769 .

72 Bohlen Minutes, Roosevelt-Churchill-Stalin meeting, November 30 , 1943, Cairo and Tehran Conferences, p. 567.

73 Bohlen Minutes, Roosevelt-stalin meeting, February 8, 1945, Yalta Conference, pp. 770-71.

${ }^{74}$ Cairo and Tehran Conferences, p. 449.

75state Department Briefing Book Paper, "Postwar Status of Korea," Yalta Conference, p. 359.

${ }^{76}$ Sherwood, II, 511 . 


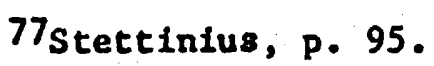

78 Ibid., p. 92.

79 Written statement by $W$. Averell Harriman, Far East Hearings, p. 3334 . 
CHAPTER IV

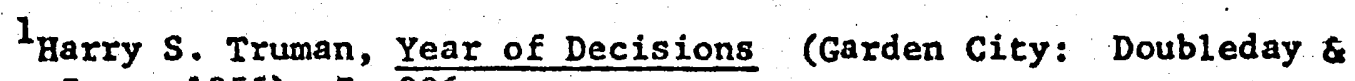
Company, Inc., 1955), I, 396 .

2Bohlen Memorandum, meeting between Hopkins-Harriman-Bohlen of the United States, and Stalin-Molotov-Pavlov of the Soviet Union, May 28, 1945, U.S. Department of State, Foreign Relations of the United States, The Conference of Berlin (The Potsdam Conference 1945) (Washington, D.C.: U.S. Government Printing Office, 1960), I, 52. Cited hereafter as Potsdam Conference.

United States Relations with China, p. 117.

4Feis, The China Tangle, p.317.

5ruman, I, 315.

6 Ibid.

7 Ibid., I, 318.

8 Telegram, Ambassador Harriman to the President and Secretary of State, July 12, 1945, Potsdam Conference, I, 862-63.

9

Ib1d.

10 Ibid.

11 Telegram, Ambassador Harriman to the President and Secretary of State, July 13, 1945, Ibid., I, 863-64.

12 Ibid.

13 Truman. I, 316-17.

14 Telegram, Hurley to Secretary of State and Harriman, July 19, 1945, Potsdam Conference, II, 1224-25.

15 Telegram, Hurley to President Truman, July 20, 1945, Potsdam Conference, II, 1225-26.

16 Potsdam Conference, II, 1241 . 
17 Soong had been reluctant to return to Moscow, knowing that in all probability that the pact with the Soviet Union would be "destructive politically to the man responsible for it," and extremely unpopular in China. He had requested that he had been relieved of the job, but was pursuaded by Hurley that he was the only man, with the exceptIon of Chiang Kai-shek, who could conclude the agreements with any degree of success. Soong, though worried that he would be ruined relented when Chiang Kai-shek agreed to name Wang Shih-chieh Foreign Minietar. Thus it was not Soong, who did root of tho retual negotiating, who signed the final treaty and agreements, but Wang Shih-chieh. Telegram, Hurley to Secretary of State, July 29, 1945, Potsdam Conference, II, 1245-46.

\section{Feis, The China Tangle, p. 343.}

${ }^{19}$ Truman, I, 424.

20 Feis, The China Tangle, p. 343.

$21_{\text {Truman, }}$ I, $423^{\circ}$.

${ }^{22}$ Feis, The China Tangle, p. 343.

23 Ibid., pp. 343-44.

24 Ibid., p. 334 .

${ }^{25}$ United States Relations with China, pp. 585-87.

${ }^{26}$ Ibid., pp. 587-89.

27 Ibid., PP. $598-91$.

${ }^{28}$ Appendix and map may be found in Ibid., pp. 591-92.

29

Ibid., Pp. 592-93.

${ }^{30}$ Ibid., pp. 593-96.

31 Ibid., p. 116.

32 Ibid., p. 117.

33 Telegram, Hurley to President Truman, June 15, 1945, as paraphrased in Feis, The China Tangle, p. 314. p. 315 .

34Telegram, Grew to Huritey, June 18,1945 , as paraphrased in Ibid.,

35 Truman, I, 317. 
36Feis, The China Tangle, p. 320.

37 Telegram, Ambassador Harriman to the President and Secretary of State, July 7, 1945, Potsdam Conference, I, p. 231.

38 Telegram, Ambassador Harriman to the President and Secretary of State, July 9, 1945, Potsdam Conference, I, p. 234.

${ }^{39}$ Document titled "U. S. Interpretation of the Yalta Agreement and Tezms which China Mighe Appropriately Accept in Regard to Outat Mongol La and Manchuria," Potsdam Conference, I, 865-72.

40 James F. Byrnes, Speaking Frank1y (New York: Harper \& Brothers Publishers, 1947), p. 205 .

41 Telegram, Hurley to the President, July 12, 1945, Potsdam Conference, II, 861 .

42See above pages 113-14 for more details concerning this message and President Truman's answer.

43Memorandum from State Department for Byrnes, July 20, 1945, Potsdam Conference, II, 1227-28.

44Memorandum, Ambassador Harriman to Secretary of State, July 28, 1945, Potsdam Conference, II, 1243-44.

45 Memorandum, Ambassador Harriman to Secretary of State, July 31, 1945, Potsdam Conference, 1246-47.

46 Ibid.

47 Forrestal Diaries, p. 78.

48 Truman, I, 423-24.

${ }^{49}$ Ibid., I, p. 424.

50 see above page 114 for additional details.

51 Truman, I, 424-25.

52 Written statement by w. Averell Harriamn, Far East Hearings, p. 3338 .

53 Feis, The China Tangle, p. 343.

54 United States Relationts with China, pp. 117-18.

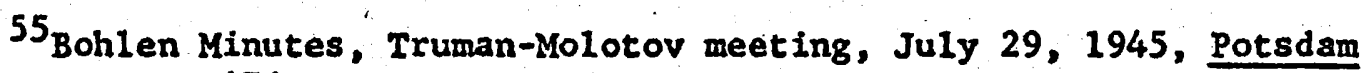
Conference, II, 476 .

56Truman, I, 401-402. 
57 Leahy, p. 422

58Memorandum from Truman to Stalin, July 31, 1945, Potsdam Conference, II, 1333-34. 
CHAPTER V

1 Report by General Marshall, The War Reports, p. 204.

2ELanhowar, Pp. 396-98.

3Ibid., p. 399.

4 Churchill, p. 397.

5 Omar N. Bradley, A Soldier's Story (New York: Henry Hold \& Company, 1951), pp. 535-36.

${ }^{6}$ Churchill, pp. 398-99.

7 Wilmot, p. 703.

8 Ibid., p. 680 .

${ }^{9}$ Ibid., PP. 704-706.

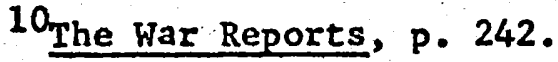

11 Ibid., pp . 239-40.

12Herbert Feis, Japan Subdued (Princeton: Princeton University Press, 1961), p. 107 .

13 Far East Hearings, PP. 2432-33.

${ }^{14}$ Robert J. C. Butow, Japan's Decision to Surrender (Stanford: Stanford University Press, 1954), p. 87.

15 Ibid., p. 89

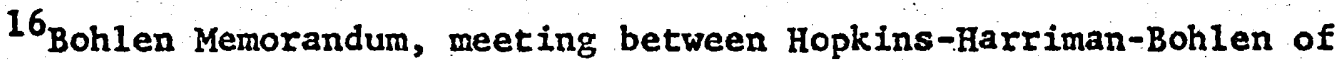
the United States and Stalin-Molotov-Pavlov of the Soviet Union, May 28, 1945, Potsdam Conference, I, 44.

17David J. Dallin, Soviet Russia and the Far East (New Haven: Yale University Press, 1948), p. 195.

${ }^{18}$ Far East Hearings, p. 2196.

19U. S. State Department, Bulletin, XII, (April 29, 1945); Pp. 811-12.

20 Butow, p. 59. 
21 Ibid., p. 88 .

22 Ibid., pp. 86-88.

${ }^{23}$ U. S. Strategic Bombing Survey, Japan's Struggle to End the War. (Washington D.C.: U.S. Government Printing Office, 1946), p.

24 Butow, pp. $90-91$.

25 Ibid., p. 121 .

26 Ibld., p. 122 .

27 Potsdam Conference, I, 874.

28 Ibid., 875-76.

29 Ib1d., I, 881.

$30_{\text {Ibid., II, 1250-51. }}$

$31_{\text {Ibid., II, 1260-61. }}$

32 Ibid. , II, 1260.

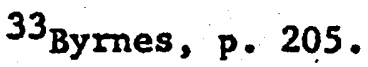

34Bohlen Notes, Truman-Stalin meeting, July 18, 1945, Potsdam Conference, II, 87.

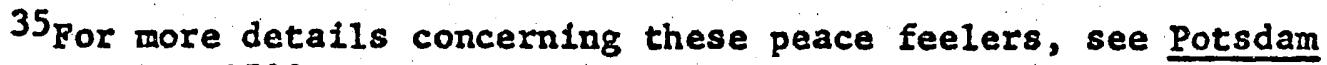
Conference, II, 1589.

36 Forrestal Diaries, p. 74.

37. Truman, I, 396.

$38_{\text {Butow, p. 153-54. }}$

${ }^{39}$ Full copy of the official report President Truman received is contained in Potsdam Conference, II, 1361-68.

${ }^{40}$ Full text of Potsdam Declaration is contained in Potsdam Conference, II, 1474-76.

41 Truman, I, 397 .

${ }^{42}$ From translation of broadcast, Potsdam Conference, II, 1293.

43 Truman, I, 421 
44 Ibid., I, 419.

45Ibid., I, 421. Plans had been prepared that, weather permitting, the bomb would be dropped on one of four targets, Hiroshima, Kokura, Nigata, or Nagasaki, on August 3, but the date was delayed. For full text of these plans see pages $420-421$.

${ }^{46}$ Potsdam Conference, II, 1377. For full text of White House Press Release pages 1376-78.

47 Toshikazu Kase, Journey to the Missouri (New Haven: Yale University Press, 1950), p. 21 .

48 Truman, 425 .

${ }^{49}$ Ibid., I, 435-37. Complete texts of surrender negotiations with Japan are contained in the Appendicies of Japan's Decision to Surrender, pp. 244-50. 
CHAPTER VI

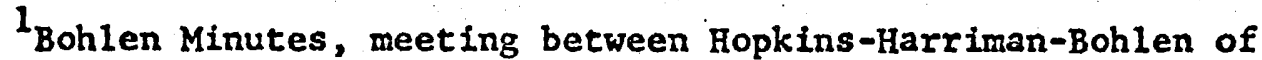
the United States, and Stalin-Molotov-Pavlov of the Soviet Union, May 28, 1945, Potsdam Conference, I, 42.

2statement by Stalin, Ibid.

3 Far East Hearings, Pp. 3055-56.

4 Statement by Secretary of State Acheson, Ibid., I, 1845.

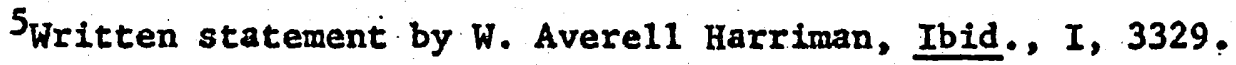

6 Ibid.

7 Truman, I, 317.

${ }^{8}$ Potsdam Conference, II; p. 1237.

Ynited States Relations with China, p. 116.

10 Far East Hearings, p. 3338.

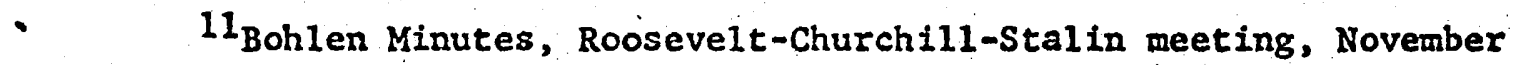
30, 1943, Cairo and Tehran Conferences, p. 567.

12United States Relations with China, pp. 125-26.

13 Ibid., p. 120 .

14 Ibid.

15U. S. Department of State, Bulletin, Vol. XIII, No. 323 (September 2, 1945), P. 333.

${ }^{16}$ Far East Hearings, p. 3335. For American editorial coment see Life magazine, September 10, 1945.

17 Ibid., p. 3339.

${ }^{18}$ Ibid., pp. $1845-46$.

${ }^{19}$ State Department Briefing Book Paper, "Unity of Anglo-AmericanSoviet Policies Toward China," Yalta Conference, P. 353.

${ }^{20}$ Anthony Kubek, How the Far East was Lost (Chicago: Heary Regnery Company, 1963), p. 111. 
21 Ibid., p. 110.

22 See above page 180 .

${ }^{23}$ State Department Briefing Book Paper, "Unity of Anglo-American Soviet Policies Toward China." Yalta Conference, p. 354.

p. 3328.

24 Written statement by $W$. Averell Harriman, Far East Hearings,

25 Ibid., p. 3335.

26chiang, p. 94.

27 Japan's Struggle to End the War, p. 13.

28 Report contained in The War Reports, p. 439.

29 Truman, I, 323.

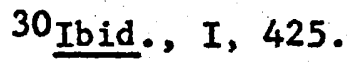

$31_{U}$. S. Joint Chiefs of Staff Minutes, meeting, June 18, 1945 , Potsdam Conference, I, 905.

32 Admiral Leahy told Truman, "That is the biggest fool thing we have ever done. The bomb will never go off, and I speak as an expert on explosives." Year of Decisions, p. 11.

33u. S. Joint Chiefs of Staff Minutes, meeting, June 18, 1945, Potsdam Conference, I, 905.

${ }^{34}$ Ibid., II, 1307.

35 Leahy, p. 383.

36 Written statement by w. Averell Harriman, Far East Hearings, p. 3338 .

${ }^{37}$ Reprint from note by Churchill in Grand Strategy, concerning Byrnes-Churchill conversation, July 23, 1945, Potsdam Conference, II 276.

38Ernest J. King and Walter Muir Whitehi11, Fleet Admiral King: A Naval Record (New York: W. W. Norton \& Company, Inc., 1952), p. 606. Document titled "Development of Operations in the Pacific," dated June 29, 1945, by United States Chiefs of Staff, Potsdam Conference, I, 910-11.

${ }^{39}$ Leahy, p. 259. 
40 Ibid., p. 422

41 Yalta Conference, pp. 356-57.

${ }^{42}$ Leahy, p. 318 .

${ }^{43}$ Ibid.

${ }^{44}$ Far East Hearings, pp. 1845-46.

45 Bohlen Minutes, Roosevelt-Churchill-Stalin meeting, November 30, 1943, Cairo and Tehran Conferences, p. 566.

${ }^{46}$ Far East Hearings, p. 3591.

47 Ibid., p. 128.

48 Ibid., p. 2829.

${ }^{49}$ Ibid., p. 2876.

50 Forresta1 Diaries, p. 31 .

- 51 Far East Hearings, p. 1881 .

52 Ibid., p. 2229.

53 Ibid., p. 3023 .

54 Ibid., p. 3051 .

55 Written statement by $W$. Averell Harriman, Ibid., Pp. 3335-36.

56 Leahy, P. 369 .

57Excerpt from Stimson's diary, Potsdam Conference, II, 1324.

58 Deane, PP. 225-26.

${ }^{59}$ United States Relations with China, p. 126.

60 Written statement by $w$. Averell Harriman, Far East Hearings, p. 3341 . 2060-61.

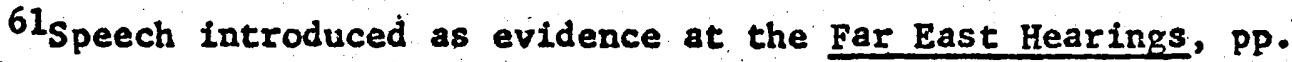

62 stettinius, p. 127 .

63Written statement by W. Averell Harriman, Far East Hearings, p. 3341 . 
64

United States Relations with China, p. 126.

65Sumner Welles, Seven Decisions that Shaped History (New York: Harper \& Brothers Publishers, 1950), P. 147. 


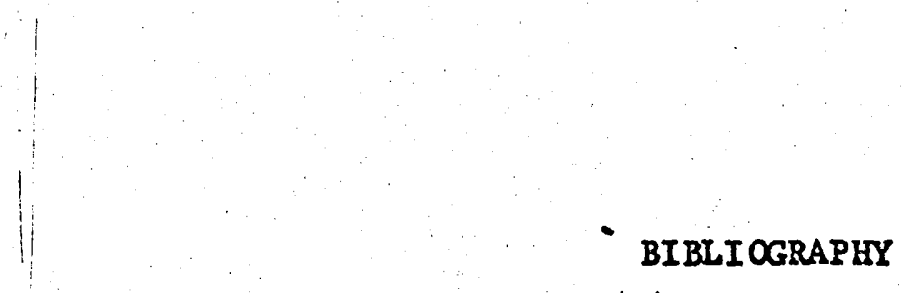




\section{A SELECTED BIBLIOGRAPHY}

UNITED STATES GOVERNMENT

DOCUNDENTS AND PUBLICATIONS

U. S. Congress, Senate Comittee on Armed Services and Foreign Relations. Hearings on the Military Situation in the Far East. 82nd Congress, Ist Session, 1951.

U. S. Congress, Senate Comnittee on Foreign Relations of the United States. A Decade of American Foreign Policy. Washington, D.C.: U. S. Government Printing Office, 1960 .

U. S. Department of State. Bulletin, Vol. XIII, No. 323 (September 2, 1945).

U. S. Department of State, Foreign Relations of the United States. The Conference of Berlin (The Potsdam Conference) 1945. 2 vols. Washington D.C.: U. S. Government Printing Office, 1960.

U. S. Department of State, Foreign Relations of the United States. The Conferences at Cairo and Tehran, 1943. Washington, D.C.: U. S. Government Printing Office, 1961.

U. S. Department of State, Foreign Relations of the United States. The Conferences at Malta and Yalta, 1945. Washington D.C.: U.S. Government Printing Office, 1955.

U. S. Department of State, Making the Peace Treaties. Washington D.C.: U. S. Government Printing Office, 1947.

U. S. Department of State, "A Pact of Neutrality Between the U.S.S.R. and Japan," Bulletin, Vol XII, No. 305 (April 29, 1945), pp. 811-812.

0. S. Department of State. Postwar Foreign Policy Preparation 1939-1945. Washington D.C.: U. S. Government Printing Office, 1949.

U. S. Department of State. United States Relations with China. Washington D.C.: Department of State Publication, Division of Publications, Office of Public Affairs, 1949..

U. S. Department of War, Strategic Bombing Survey, Japan's Struggle to End the War. Washington D.C.: U. S. Government Printing Office, 1946. 
U. S. Twenty-First Report to Congress on Lend-Lease Operations: For the Period ended September 30, 1945. (Mimeographed for distribution to Congress) 
MOMOIRS AND PERSONAL ACCOUNTS

Bradley, Omar N. A Soldier's Story. New York: Henry Hold and Company, 1951.

Byrnes, James F. Speaking Frank1y. New York: Harper \& Brothers PubIishers, 1947.

Chiang Kai-shek. Soviet Russia in China. New York: Farrar, Straus and Giroux, 1965.

Churchill, Winston S. Triumph and Tragedy. New York: Bantam Books, 1962.

Deane, John R. The Strange Alliance. New York: The Viking Press, 1947.

Eisenhower, bwight D. Crusade in Europe. Garden City: Garden City Books, 1948.

Groves, Leslie R. Now It Can Be Told: The Story of the Manhattan Project. New York: Harper \& Row, Publishers, 1962 .

Hu11, Corde11. The Memoirs of Corde11 Hu11. Vo1. II. New York: The Viking Press, 1948 .

Kase, Toshikazu. Journey to the Missouri. New Haven: Yale University Press, 1950.

King, Ernest J., and Whitehil1, Walter Muir. Fleet Admiral King: A Nava1 Record. New York: W.W. Norton \& Company, Inc., 1952.

Leahy, William D. I Was There. New York: McGraw-Hill Book Company, Inc., 1950.

MacArthur, Douglas. Reminiscences, New York: McGraw Hill Book Company, Inc., $196 \overline{\text {. }}$

Millis, Walter (ed.). The Forrestal Diaries. New York: The Viking Press, 1951.

- The War Reports of George C. Marsha11, H. S. Arnold, Ennest J. King. Philadelphia: J. B. Lipincott Company, 1947.

Morison, Samuel Eliot. The Battles of the Atlantic: September 1939May 1943. Vol. I. Boston: Little Brown and Company, 1960. 
- The Two-Ocean War. Boston: Little, Brown and Company, 1963.

Shigemitsu, Mameru. Japan and Her Destiny. New York: E. P. Dutton \& Company Inc., 1958.

Stettinius, Edward R. Jr. Lend Lease: Weapon for Victory. New York: The MacMillan Company, 1944.

- Roosevelt and the Russians: The Yalta Conference. Garden City: Doubleday \& Company, Inc., 1949.

Stilwe11, Joseph $W$. The Stilwell Papers. New York: William Sloan Assoclates, Inc., 1948 .

Stimson, Henry L., and Bundy, McGeorge. On Active Service in Peace and War. New York: Harper \& Brothers, 1947.

Truman, Harry S. Year of Decistons. Vol. I. Gaxden City: Doubleday \& Company, Inc., 1955.

Welles, Sumner. Seven Decisions that Shaped History. New York: Harper \& Brothers Publishers, 1950.

- Where Are We Heading? New York: Harper \& Brothers Publishers, 1946. 


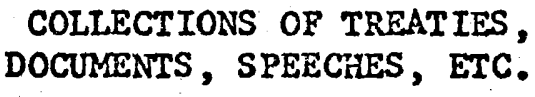

Fu, Lo-Shu. A Documantary Chronicle of Simo-Wantern Rolatione (16441820). 2 Vols. Tuscon: The University of Arizona Press, 1966.

Hertslet, Sir Edward. Treaties, between Great Britain, China and Foreign Powers. 2 Vols. London: Harrison and Sons, 1908.

Holburn, Louise W. (ed.), War and Peace Ains of the United Nations. 2 Vols. Boston: World Peace Foundation, 1948.

MacMurray, John V. A. (ed.). Treaties and Agreements with and Concerning China, 1894-1919. 2 Vols. New York: Oxford University Press, 1921.

Snyder, Louis L. (ed.). Documents of German History. New Brunswisk: Rutgers University Press, 1958. 
GENERAL WORKS OF IMPORTANCE

Bau, Mingchien Joshau. The Foreign Relations of China. New York: Flaming $H$, Raval1 Cothingy, 1921.

Buss, Claude A. The Far East. New York: The MacMillan Company, 1955.

Butow, Robert J. C. Japan's Decision to Surrender. Stanford: Stanford University Press, 1954.

Cheng, Tien-fong. A History of Sino-Soviet Relations. Washington D.C.: Public Affairs Press, 1960.

Feis, Herbert. Between War and Peace. Princeton: Princeton University Press, 1960.

- The China Tangle. Princeton: Princeton University Press, 1953.

- Japan Subdued. Princeton: Princeton University Press, 1961.

Fleming, D.F. The Cold War and Its Origins. Vol. I. Garden City: Doubleday \& Company, Inc., 1961.

Griswold, Alfred Whitney. The Far Eastern Policy of the United States. New York: Harcourt, Brace and Company, 1938.

Rubek, Anthony. How the Far East was Lost. Chicago: Henry Regnery Company, 1963.

Malozemoff, Andrew. Russian Far Eastern Policy, 1881-1904. Berkeley: University of California Press, 1958.

Mazour, Anatole G. Russia: Tsarist and Communist. New York: D. Van Nerstrand Company, Inc., 1962.

Neumann, william L. Making the Peace 1941-1945. Washington D.C.: Foundation for Foreign Affairs, 1950.

Price, Ernest Batson. The Russo-Japanese Treaties of 1907-1916, Concerning Manchuria and Nongolia. Baltimore: The John Hopkins Press, 1933.

Schuman, Frederick L. Russia Since 1917: Four Decades of Soviet Politics. New York: McGraw-Hil1 Book Company, Inc., 1957. 
Sherwood, Robert E. Roosevelt and Hopkins. 2 Vols. New York: Bantam Books, 1950.

Sne11, John I. (ed.). The Meaning of Yalta. Baton Rogue: Louisiana State University Press, 1956.

Valeo, Frances. The China Wite Paper. Washington D.C.: The Library of Congress, 1949.

Vinacke, Harold M. Far Eastern Politics in the Postwar Perlod. New York: Appleton-Century-Crofts, Inc., 1956.

- A History of the Far East in Modern Times. New York: AppletonCentury-Crofts, Inc., 1950.

Weigh, Ken Shen. Russo-Chinese D1plomacy 1689-1924. Russian Series, Vo1. 3. Bangor: University Prints, 1928.

Wilmot, Chester. The Struggle for Europe. New York: Harper \& Brothers Publishers, 1952. 
GENERAL WORKS

Alperovits, Gar. Atomic Diplomacy: Hiroshima and Potsdam. New York: Alfred A. Knopf, Inc., 1965.

Bailey, Thomas A. A Diplomatic History of the American People. New York: Appleton-Century-Crofts, 1964.

Beens, F. Lee. Europe Since 1914, In its World Setting. New York: Appleton-Century-Crofts, Inc., 1949.

Bisson, T.A. American Policy in the Far East 1931-1940. New York: Institute of Pacific Relations, 1940.

Cameron, Meribeth E., and Mahoney, Thomas, H. D., McReynolds, George E. China, Japan and the Powers. New York: The Ronald Press Company, 1960.

Clubb, Edmund 0. 20th Century China. New York: Columbia University Press, 1964.

Dallin, David J: Soviet Russia and the Far East. New Haven: Yale University Press, 1948.

Feis, Herbert. Churchill-Roosevelt-Stalin. Princeton: Princeton University Press, 1957.

- The Road to Pearl Harbor. Princeton: Princeton University Press. 1950 .

Florinsky, Michael T. Russia: A Short History. New York: The MacMillan Company, 1964.

Kajima, Morinosuke. A Brief Diplomatic History of Modern Japan. Rutland: Charles E. Tuttle Co., Publishers, 1962.

Link, Arthur S. American Epouch. New York: Alfred A. Knopf, 1963.

Liu, F. F. A Military History of Modern China, 1924-1945. Princeton: Princeton University Press, 1956.

Roberts, Les1le. Home From the cold Wars. Boston: The Beacon Press, 1958 .

Schuman, Frederick L. International Politics. New York: McGraw-Hill Book Company, 1958 . 
Vinacke, Harold M. The United States and the Far East 1945-1951. Stanford: Stanford University Press, 1962. 


\section{ARTICLES}

Stimson, Henry L. "The Decision to Use the Atomic Bomb," Harper's Magazine. Vo1. 194, No. 1161 (Fobruary, 1947), Pp. 97-107. 